\title{
26. LITHOLOGIC INTERPRETATION OF CONTINUOUS REFLECTION PROFILING, DEEP SEA DRILLING PROJECT, LEG $7^{1}$
}

\author{
Loren Kroenke and Ralph Moberly, Jr., \\ Hawaii Institute of Geophysics, Honolulu, Hawaii, \\ E. L. Winterer, Scripps Institution of Oceanography, La Jolla, California, \\ and \\ G. Ross Heath, Oregon State University, Corvallis, Oregon
}

\section{INTRODUCTION}

In an early review article on continuous reflection profiling, Hersey (1963) listed the methods used in the geologic interpretation of profiler records. They include: association with known rocks or sediments, for example from bottom cores; tracing of an in-shore subbottom reflection to an outcrop ashore; comparison of shallow-water profiles with penetration characteristics measured by the number of blows required to penetrate a unit thickness of bottom materials; and measurement of the characteristics of rocks and sediments that affect the velocity of sound in them. The intervening several years have brought advances in equipment and techniques, as well as many significant interpretations of results. One of the more notable was the correlation of Horizon A near the Bahama escarpment with Upper Cretaceous calcareous turbidites (Ewing et al., 1966). However, the advent of the Deep Sea Drilling Project which is fulfilling the hope expressed by Hersey (1963) that non-commercial research would finance coring deeper than a few tens of feet in deep water has been the major aid to better interpretation of continuous reflection profiles. Moreover, the drilling evidence has forced re-evaluation of some of the earlier correlations and interpretations; thus, the Horizon A reflector has proved to be Early-Middle Eocene chert at most Atlantic sites (Gartner, 1970; Ewing et al., 1970).

The present article is a status report on the interpretation of sub-bottom lithology represented on continuous seismic profiles of the western and central tropical Pacific. It is based largely on information obtained on Leg 7 of the Deep Sea Drilling Project. Shipboard measurements of physical properties of cores, the on-site matching of air-gun records to depths drilled to particular horizons, and the air-gun records between sites that are abstracted below are reported in detail elsewhere in this volume. Measurements ashore on Leg 7 samples are tabulated below (Table 1). We have also considered the information and data, largely

\footnotetext{
${ }^{1}$ Hawaii Institute of Geophysics Contribution No. 000.
}

published, from samples, cores, sonobuoy wide-angle refraction-reflection records, and continuous reflection profiles from SCAN and other expeditions. Scientists of Scripps Institution of Oceanography, Lamont Geological Observatory, and Hawaii Institute of Geophysics have gathered most of that information.

During Leg 7, the D/V Glomar Challenger traversed about 15 major areas of the sea-floor that are sufficiently different in physiography and in continuous reflection profile characteristics indicative of differences in structure, stratigraphy, and perhaps tectonic history, so that each may be conveniently discussed as an entity (Figure 1). Probably they are analogous to geological provinces on continents (Field, 1933). Each is described in the order of crossing during Leg 7. Typical profiles are shown on Figure 2 and our interpretations are summarized in Table 2.

\section{MARIANA TRENCH}

The Mariana Trench was crossed three times: from Guam to Site 61 , from Site 61 back to Guam, and from Guam to Site 62. The air-gun system was operating poorly or not at all. A track of the R/V Argo during SCAN (site survey) was parallel and about 10 miles north of the first crossing. Site $60, \operatorname{Leg} 6$, was immediately west of the trench (Fischer et al., 1970). There was no drilling possible on either leg in the deep water of the Trench proper, and so there are neither samples nor records to discuss.

\section{MARIANA BASIN}

The southwest corner of the Mariana Basin contains Site 61 and was crossed between Guam and Site 62 . Site 59 of Leg 6 is near Site 61. Reflection profiles obtained during SCAN show an upper transparent layer, a middle opaque layer, a lower transparent layer, and one or more basement reflectors. The upper layer is soft siliceous ooze, probably mainly of Neogene age (Site 59). The first hard layers, at 72 meters depth (Site 61), are Upper Cretaceous. The induration of these porcelanites, tuffs and cherts, in contrast to their precourser pelagic clay, ash and ooze is shown by the 
TABLE 1

Seismic Velocities of Rocks Cored on Leg 7

\begin{tabular}{|c|c|c|c|c|}
\hline \multirow[b]{2}{*}{ Sample Designation $^{\mathrm{a}}$} & \multicolumn{2}{|c|}{ Depth (Meters) } & \multirow{2}{*}{$\begin{array}{c}\mathrm{V}_{\mathrm{p}^{\prime}} \\
\left(\mathrm{km} \mathrm{sec}^{-1}\right)\end{array}$} & \multirow[b]{2}{*}{ Comments } \\
\hline & Subsurface & Subbottom & & \\
\hline \multicolumn{5}{|l|}{ Chalk } \\
\hline \multirow[t]{2}{*}{$63-1-11-2,107 \mathrm{~cm}$} & 4627 & 155 & 1.62 & Soft; horizontal (parallel to bedding) \\
\hline & & & 1.70 & Soft; vertical (across bedding) \\
\hline \multirow[t]{2}{*}{$63-1-10-3,17 \mathrm{~cm}$} & 4622 & 150 & 1.63 & Horizontal \\
\hline & & & 1.77 & Vertical \\
\hline \multirow[t]{2}{*}{$63-1-12-2,45 \mathrm{~cm}$} & 4660 & 167 & 1.66 & Horizontal \\
\hline & & & 1.68 & Vertical \\
\hline \multirow[t]{2}{*}{$63-1-13-6,78 \mathrm{~cm}$} & 4655 & 183 & 1.73 & Horizontal \\
\hline & & & 1.70 & Vertical \\
\hline \multirow[t]{2}{*}{$64-1-1-4$} & 2486 & 436. & 1.74 & Horizontal \\
\hline & & & 1.93 & Vertical \\
\hline \multirow[t]{2}{*}{$62-1-36-5,130 \mathrm{~cm}$} & 2934 & 343 & 2.11 & Horizontal \\
\hline & & & 2.02 & Vertical \\
\hline \multirow[t]{2}{*}{$63-0-8-1,113 \mathrm{~cm}$} & 5016 & 544 & 2.40 & Orange-pink chalk; horizontal \\
\hline & & & 2.11 & Vertical \\
\hline $64-0-7-1,40 \mathrm{~cm}$ & 2659 & 609 & 1.86 & Not oriented \\
\hline $64-1-7-\mathrm{CC}$ & 2714 & 664 & 1.93 & Not oriented \\
\hline $64-0-10-1,82 \mathrm{~cm}$ & 2901 & 849 & 2.05 & Not oriented \\
\hline \multicolumn{5}{|l|}{ Limestones } \\
\hline \multirow[t]{2}{*}{ 64-1-7-1-Top } & 2718 & 660 & 2.12 & Horizontal \\
\hline & & & 1.95 & Vertical \\
\hline \multirow[t]{2}{*}{$64-1-6-2$} & 2618 & 568 & 2.11 & Horizontal \\
\hline & & & 1.97 & Vertical \\
\hline $64-1-10-1,28 \mathrm{~cm}$ & 3019 & 959 & 2.07 & Not oriented \\
\hline $64-0-10-1,27 \mathrm{~cm}$ & 2901 & 849 & 2.26 & Not oriented \\
\hline $64-0-10-2,36 \mathrm{~cm}$ & 2902 & 850 & 2.53 & Not oriented \\
\hline
\end{tabular}


TABLE 1 - Continued

\begin{tabular}{|c|c|c|c|c|}
\hline \multirow[b]{2}{*}{ Sample Designation } & \multicolumn{2}{|c|}{ Depth (Meters) } & \multirow{2}{*}{$\begin{array}{c}\mathrm{V}_{\mathrm{p}} \\
\left(\mathrm{km}, \mathrm{sec}^{-1}\right)\end{array}$} & \multirow[b]{2}{*}{ Comments } \\
\hline & Subsurface & Subbottom & & \\
\hline \multicolumn{5}{|l|}{ Nannofossil Marl } \\
\hline \multirow[t]{2}{*}{$63-0-9-1,136 \mathrm{~cm}$} & 5027 & 555 & 2.29 & Horizontal \\
\hline & & & 2.22 & Vertical \\
\hline \multirow[t]{2}{*}{$63-0-9-3,116 \mathrm{~cm}$} & 5030 & 558 & 2.50 & Horizontal \\
\hline & & & 2.33 & Vertical \\
\hline \multicolumn{5}{|l|}{ Stiff Pelagic Clay } \\
\hline \multirow[t]{2}{*}{$66-0-7-3$} & 5470 & 177 & 1.49 & Horizontal \\
\hline & & & 1.61 & Vertical \\
\hline \multicolumn{5}{|l|}{ Porcelanite } \\
\hline $67-1-2-\mathrm{CC}$ & 4532 & 59 & 2.74 & Not oriented \\
\hline \multirow[t]{2}{*}{$65-1-6-\mathrm{CC}$} & 6300 & 170 & 3.74 & Horizontal \\
\hline & & & 3.46 & Vertical \\
\hline \multicolumn{5}{|l|}{ Cherty Limestone } \\
\hline \multirow[t]{3}{*}{ 64-1-11-CC } & 3033 & 983 & 4.05 & $\begin{array}{l}\text { One-third blebs and stringers, } \\
\text { two thirds limestone; horizontal }\end{array}$ \\
\hline & & & 4.18 & Same; vertical \\
\hline & & & 4.50 & $\begin{array}{l}\text { One-half chert blebs and stringers, } \\
\text { one-half limestone; vertical }\end{array}$ \\
\hline \multicolumn{5}{|l|}{$\begin{array}{l}\text { Volcanogenic Sandstones } \\
\text { and Mudstones }\end{array}$} \\
\hline \multirow[t]{2}{*}{$67-1-1-\mathrm{CC}$} & 4498 & 25 & 1.41 & $\begin{array}{l}\text { Soft, muddy sandstone; not } \\
\text { oriented; lowest reading of any } \\
\text { orientation }\end{array}$ \\
\hline & & & 1.56 & Same, highest reading \\
\hline $67-0-1-1,145 \mathrm{~cm}$ & 4476 & 3 & 2.00 & $\begin{array}{l}\text { Muddy sandstone; not oriented; } \\
\text { highest reading }\end{array}$ \\
\hline \multirow[t]{2}{*}{$67-1-1-\mathrm{CC}$} & 4498 & 25 & 1.92 & Volcanic sandstone; horizontal \\
\hline & & & 2.26 & Vertical \\
\hline
\end{tabular}




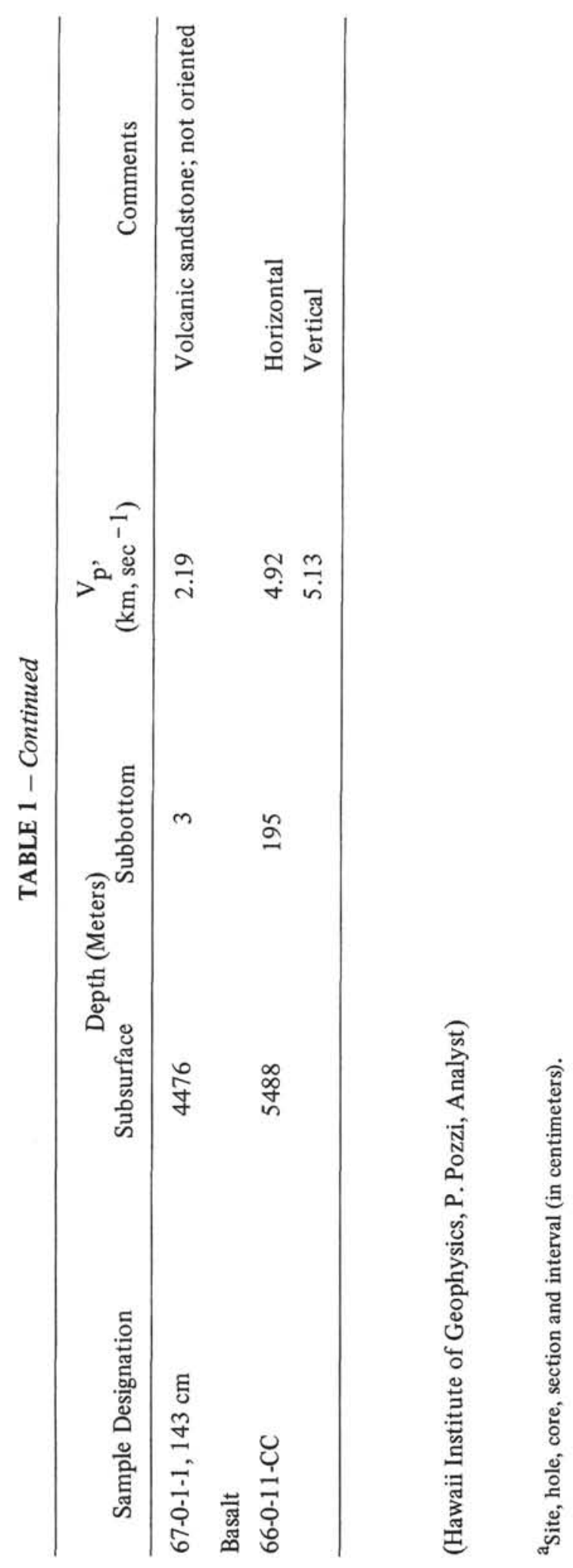

variety of lithologies recovered at Site 61 . The harder beds appear to be thin stringers within the thicker soft section, and the opaque appearance on the profiles probably results from this layering. The 85 -millisecond (msc) interval to the first reflector gives a group velocity of $1.7 \mathrm{~km} \mathrm{sec}^{-1}$ for the upper transparent layer if the first hard beds at 72 meters are the top of the opaque layer, as they almost certainly are. It is therefore reasonable to match the reflector at 95 milliseconds with the top of the true cherts and that 105 milliseconds with the top of the basalt.

Interpretation of the lower part of the reflection profiles is more difficult. Basalt was cored in one hole at 93 meters, and in the re-drill at 89 and possibly at 96 meters with soft layers between. At Site 61, it therefore appears that basalt makes up part of the middle opaque layer. The deepest reflector is at about 145 milliseconds. As discussed in the Site Report chapter, the lower transparent layer may represent a section of pre-latest Cretaceous sediment, overlain by basalts and underlain, at about 145 milliseconds, by older basalts of the "true" oceanic crust. Perhaps the younger basalts are genetically related to seamounts, toward which records show the middle layer to thicken and become more opaque. However, the true nature of the lower part of reflection profiles of this part of the Mariana Basin remains unknown.

\section{CAROLINE RIDGE}

The Caroline Ridge (Fischer and others, 1970), formerly termed the Caroline Swell (Hess, 1948; Menard, 1964), separates the Mariana Basin from the Caroline Basins. Structurally, the Caroline Ridge appears to be a great horst. Its north flank is cut by many parallel, longitudinal gravity faults. The south flank, where crossed by the Leg 7 traverse from Guam to Site 62, is marked by the Sorol Fault, showing in the bathymetry as a narrow ridge and trough striking ESE-WNW.

The subbottom profile records can be divided into (1) basement, and (2) an upper layer, 0 to 0.35 seconds thick on the fault blocks of the north flank and 0.35 to 0.55 seconds thick across the crest. No holes were drilled here during Leg 7, but at Sites 57 and 58, drilled during Leg 6, basalt was encountered below a Neogene section, and at Sites 55 and 56 the holes ended in the Upper Oligocene, apparently near or on basement. For this part of the Caroline Ridge, basement is basalt and the upper layer is Neogene sediment.

\section{EAURIPIK RIDGE}

Hess (1948) considered the Eauripik Swell to be a prong or subsidiary swell extending southward from the Caroline Swell and separating the East and West Caroline Basins. Eauripik Ridge, as it is now termed, was traversed by the Glomar Challenger southward 


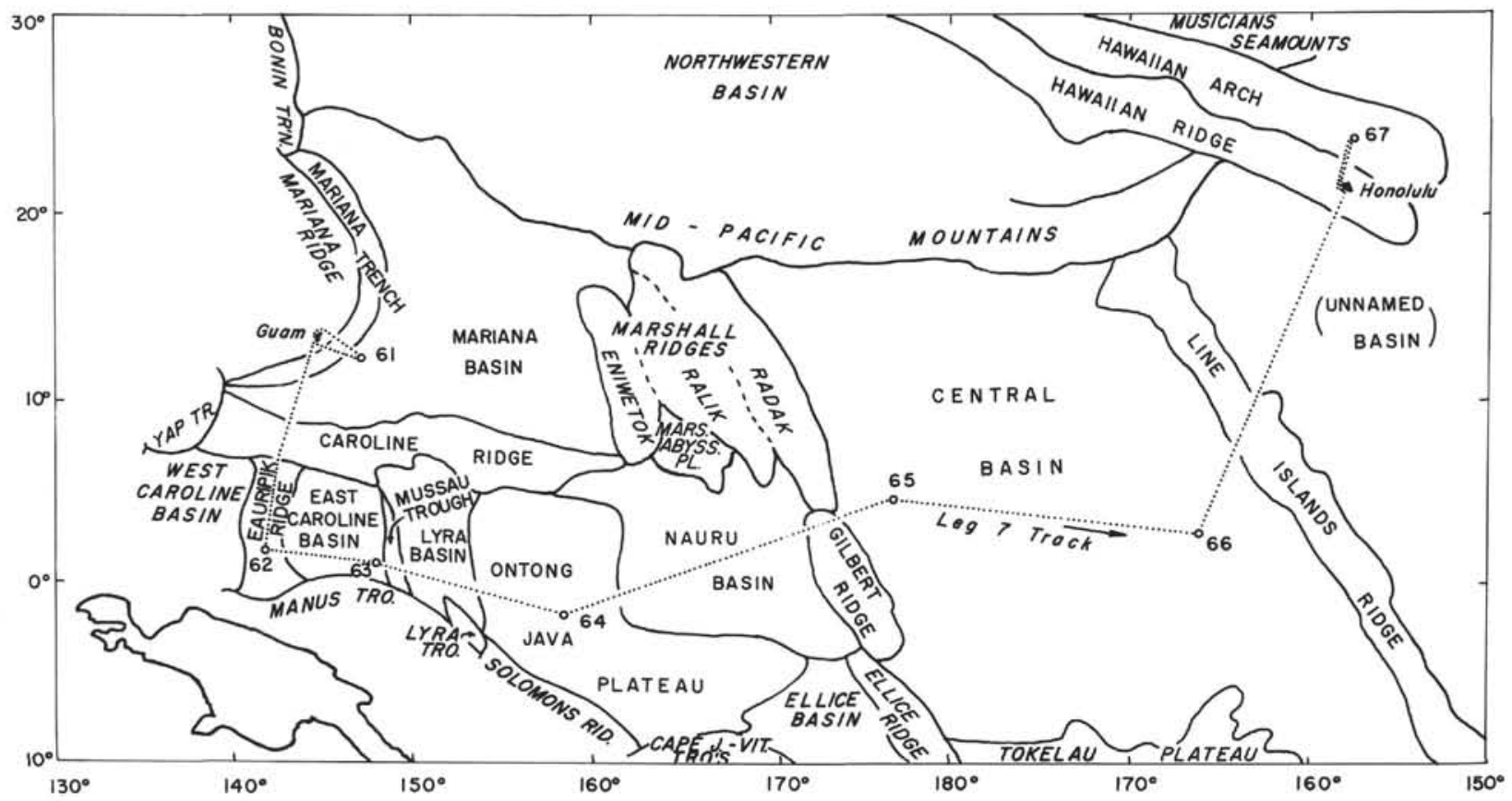

Figure 1. Submarine geological provinces of the western and central tropical Pacific Ocean crossed by D/V Glomar Challenger on Leg 7. Adjacent provinces in italics.

along its crest to about $1^{\circ} 52^{\prime} \mathrm{N}$ where Site 62 was drilled. Along the track the reflection profile shows about 0.6 seconds of section over a strong reflectiontermed basement. Persistent reflectors within the sequence appear to be absent, but this may be due to instrumental problems which seriously degraded the initial profiles.

The relationship of Eauripik Ridge to the East and West Caroline Basins is shown in Figure 3. Although the Caroline Ridge, Eauripik Ridge and the Caroline Basins differ structurally from one another, their sections are similar: calcareous Neogene sediments overlying basaltic basement.

At Site 62 near the crest of the Eauripik Ridge the Neogene section was comprised of foraminiferal, nannofossil, chalk ooze grading downward into nannochalk to nannochalk limestone with flinty chert near the base of the column. These sediments were underlain by basalt, intrusive into upper Oligocene nannofossil chalk that altered to dolomite. Reflection hyperbolas in the lower part of the profile suggests the proximity of piercement structures, probably igneous in nature. This interpretation, coupled with an abrupt increase in the depth to acoustic basement east of the site suggests that an older basaltic crust may lie slightly to the east and as much as 100 meters stratigraphically lower than the oldest sediment cored at Site 62 .

\section{EAST CAROLINE BASIN}

The East Caroline Basin, situated between the Eauripik Ridge and the Mussau Trough was crossed by the Glomar Challenger en route to Site 63. A well-stratified section is seen in the reflection profiles to overlie a persistent, well-defined basal reflector, again considered to be basement. Although the section is disturbed or interrupted by basement uplifts, faulting, and intrusive-like buried cycloidal hills, no variation is observed in the reflection character to indicate any change in lithology.

Two reflectors were correlated between Sites 62 and 63. Although the correlation of the lower reflector is tenuous, the correlation of the upper reflector appears good. Moreover, the upper reflector probably is isochronous, because the same Early Middle Miocene age was determined from fossils from both Sites 62 and 63 where the reflector was penetrated at about 390 and 140 meters, respectively.

The lower part of the section appears more disturbed with the sediment draped over, or deformed by the cycloidal hills. Whether the structure results from compaction folding, deformation during intrusive emplacement, or faulting up of the subjacent basement, is problematical and cannot be resolved from these records alone. Notwithstanding, the lower part of the sedimentary section is more deformed than the upper part, and thereby suggests active tectonism between early Oligocene and early middle Miocene. 

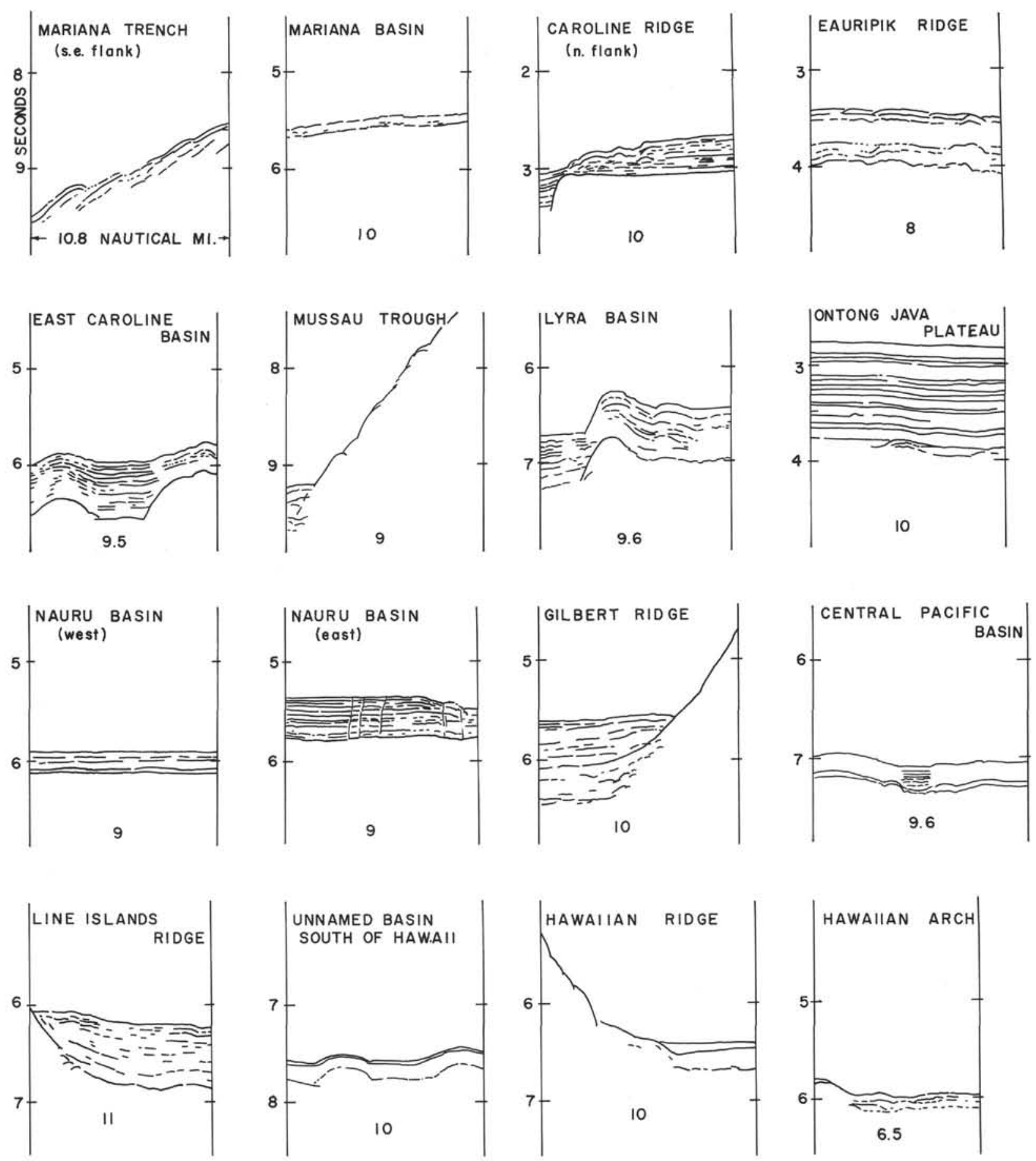

Figure 2. Characteristics of reflection profiler records of geological provinces of the western and central tropical Pacific Ocean crossed by D/V Glomar Challenger on Leg 7. Compare with Table 2.

Furthermore, the lower part more than doubles in thickness between Sites 62 and 63 , whereas the upper sediments thin to less than half. A cessation of the tectonic activity post-early middle Miocene is postulated from the eastward thinning of the section above the marker reflector. The thinning can be succinctly explained by increased solution of carbonate at the greater depths observed to the east. 
TABLE 2

Summary of Interpretation of Reflection Profile Records, Leg 7

\begin{tabular}{|c|c|c|}
\hline Province & Record (see Figure 2) & Interpretation of Age and Lithology \\
\hline \multirow[t]{2}{*}{$\begin{array}{l}\text { Mariana Trench } \\
\text { (east flank) }\end{array}$} & a. Partly-contorted layer & $\begin{array}{l}\text { Unknown, probably slumped Mesozoic } \\
\text { and Cenozoic sediment }\end{array}$ \\
\hline & b. Basement & Unknown, probably Mesozoic basalt \\
\hline \multirow[t]{4}{*}{ Mariana Basin } & a. Transparent layer & Neogene siliceous ooze \\
\hline & b. Opaque layer & $\begin{array}{l}\text { Late Cretaceous soft clay, ash, and ooze } \\
\text { interbedded with porcelanite, tuff, and } \\
\text { chert (and basalt?) }\end{array}$ \\
\hline & c. Transparent layer & $\begin{array}{l}\text { Unknown, possibly pre-Latest Cretaceous } \\
\text { sediment }\end{array}$ \\
\hline & $\begin{array}{l}\text { d. Basement (one or more } \\
\text { reflectors) }\end{array}$ & Unknown, probably Mesozoic basalt \\
\hline \multirow[t]{2}{*}{ Caroline Ridge } & a. Stratified layer & Neogene calcareous ooze and chalk \\
\hline & b. Basement & Oligocene (?) basalt \\
\hline \multirow[t]{2}{*}{ Eauripik Ridge } & a. Stratified layer & $\begin{array}{l}\text { Neogene calcareous ooze, chalk, and } \\
\text { limestone }\end{array}$ \\
\hline & b. Basement & Oligocene (?) basalt \\
\hline \multirow[t]{2}{*}{ East Caroline Basin } & a. Well-stratified layer & $\begin{array}{l}\text { Neogene pelagic marls over calcareous } \\
\text { ooze and chalk }\end{array}$ \\
\hline & b. Basement & Oligocene basalt \\
\hline \multirow[t]{2}{*}{ Mussau Trough } & a. Partly-contorted layer & $\begin{array}{l}\text { Unknown, probably slumped Cenozoic } \\
\text { calcareous sediments }\end{array}$ \\
\hline & b. Basement & Unknown, probably Paleogene basalt \\
\hline \multirow[t]{2}{*}{ Lyra Basin } & a. Well-stratified layer & $\begin{array}{l}\text { Unknown, probably Cenozoic calcareous } \\
\text { sediments }\end{array}$ \\
\hline & b. Basement & $\begin{array}{l}\text { Unknown, probably Paleogene or Late } \\
\text { Cretaceous basalt }\end{array}$ \\
\hline \multirow[t]{4}{*}{ Ontong Java Plateau } & a. Thick, well-stratified layer & $\begin{array}{l}\text { Paleogene and Neogene calcareous ooze, } \\
\text { chalk, and limestone }\end{array}$ \\
\hline & b. Prominent reflector & Middle Eocene chert and limestone \\
\hline & c. Basement & $\begin{array}{l}\text { Unknown, probably Paleogene or Late } \\
\text { Cretaceous basalt }\end{array}$ \\
\hline & d. Some deeper reflectors & Unknown, possibly older crust? \\
\hline \multirow[t]{2}{*}{ Nauru Basin } & $\begin{array}{l}\text { a. Transparent layer, or } \\
\text {-Conformable, well- } \\
\text { stratified layer, or } \\
\text {-Topographically-controlled, } \\
\text { well-stratified layer }\end{array}$ & $\begin{array}{l}\text { Cenozoic radiolarian ooze } \\
\text {-Unknown, probably Cenozoic } \\
\text { calcareous sediments } \\
\text {-Cenozoic turbidites }\end{array}$ \\
\hline & b. Basement & Mesozoic (?) basalt \\
\hline Gilbert Ridge & $\begin{array}{l}\text { a. Topographically-controlled, } \\
\text { well-stratified layer, or } \\
\text {-Transparent layer }\end{array}$ & $\begin{array}{l}\text { Late Cenozoic turbidites } \\
\text {-Late Cenozoic radiolarian ooze }\end{array}$ \\
\hline
\end{tabular}




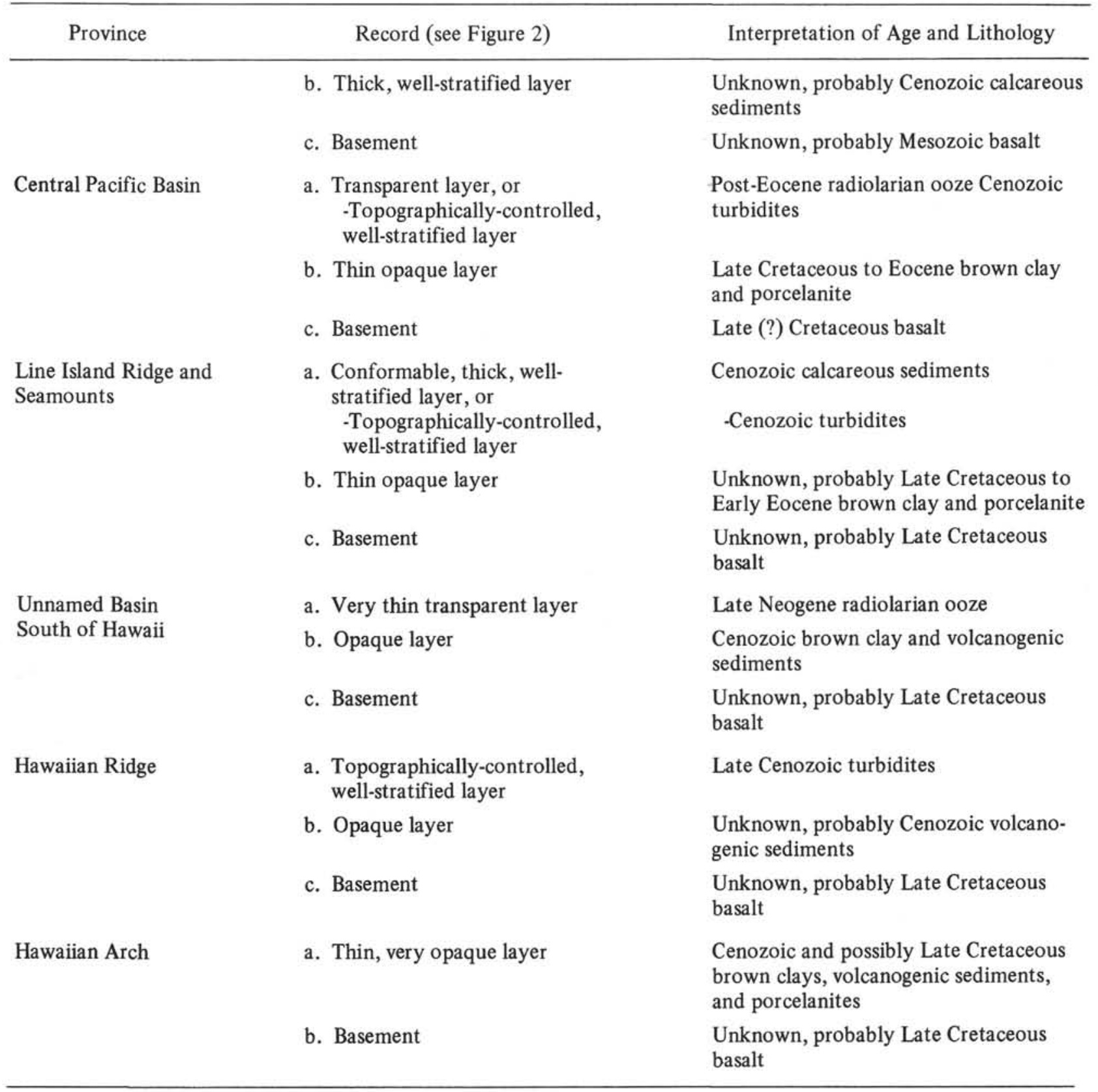

\section{MUSSAU TROUGH}

The Mussau Trough was crossed by the Glomar Challenger en route to Site 64 . In section view the west flank resembles a broad, sediment-covered homoclinal fold or flexure, dipping east and terminating beneath a flat floor, formed by ponded sediment in 7100 meters of water. The lithology of the sediment on the lower slopes of the Trough and that of the Trough itself is difficult to estimate directly from the reflection profiles. Steep slopes and deformed layering which resulted in poor reflection quality precluded correlation of lithology into and across the Trough. Notwithstanding, the lithology of the lower part of the section probably consists mainly of slumped Cenozoic calcareous sediment. The east flank is a steep escarpment rising to a crest in water 3687 meters deep along the track. The east flank also appears to be block-faulted and indeed a small block appears to be buried beneath the ponded sediment of the trough floor. 


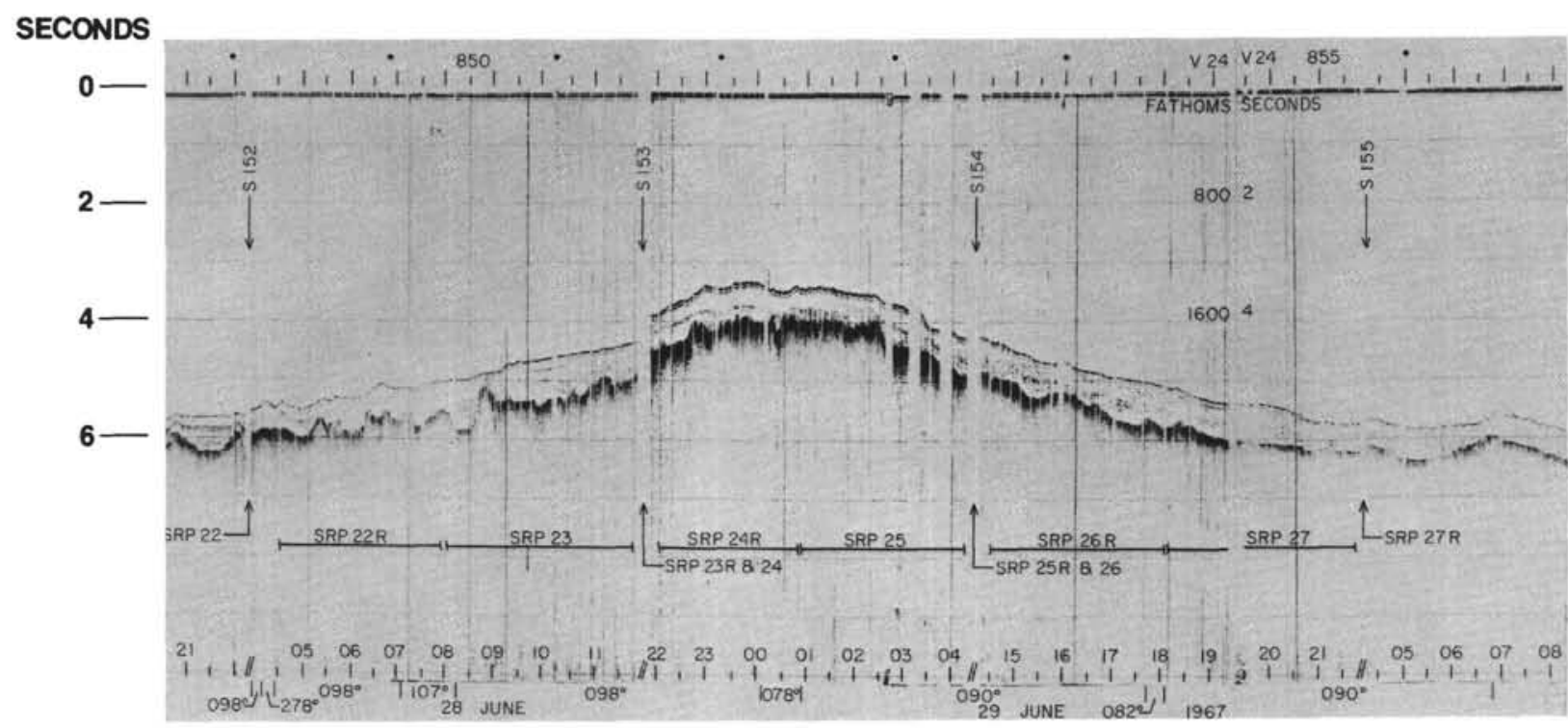

APPROXIMATE SCALE
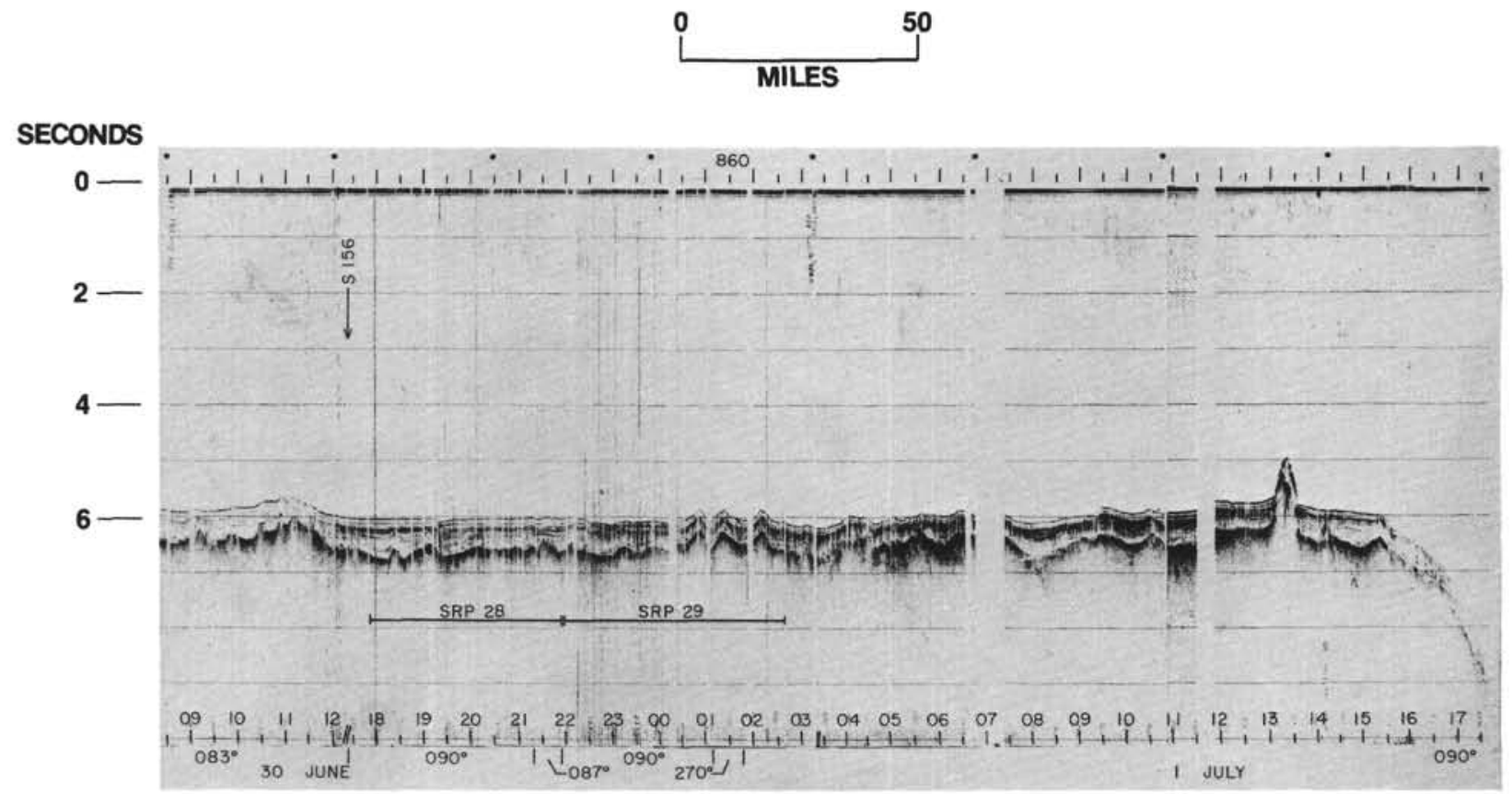

Figure 3. Reflection profiler records of Eauripik Ridge (upper) and East Caroline Basin (lower) obtained by R/V Vema in 1967. The West Caroline Basin is at the left (west) side of Eauripik Ridge; the Mussau Trough is at the extreme right (east) of the East Caroline Basin.

The feature was called the Mussau Fault by Hess (1948) who favored a transcurrent interpretation, citing the steep eastern escarpment flanking a rise whose maximum elevation is displaced to the north of the maximum depth of the adjacent depression, as evidence of left lateral displacement.

\section{LYRA BASIN}

The Lyra Basin is broad, deep depression intervening between the Mussau Trough and the Ontong Java Plateau. The deepest area is in the center of the southern end of the Basin, where the Lyra Trough 
reaches a depth of 5742 meters. The sedimentary section exhibits similar acoustic character, revealed in the reflection profiles, to that observed in both the adjacent East Caroline Basin and Ontong Java Plateau. Consequently, the lithology is assumed to be similar.

The Lyra Basin resembles a structural basin in profile with step faults characterizing both eastern and western boundaries. Step faulting down from the Mussau escarpment on the west and the Ontong Java Plateau on the east, the intervening horsts and grabens-together with the resemblance of the Lyra Trough to a graben, and an overly thick, probably carbonate section, all tend to suggest that the Lyra Basin Province is a foundered section of the adjoining Ontong Java Plateau.

\section{ONTONG JAVA PLATEAU}

The Ontong Java submarine plateau, discussed in the report for Site 64 in this volume, is approximately 750 kilometers wide and over 1500 kilometers long. It strikes northwest-southeast, paralleling the Solomon Islands (Figure 4). Water depth varies around 1700 meters in the central portion of the Plateau. The salient geologic features of the Plateau, in addition to the great areal extent and unusually shallow ocean depth, include: the complex submarine physiography of the Plateau margins; the very thick, highly stratified, conformable sediments of the Plateau proper; and the anomalously thick ocean crust (Woollard and others, 1967; Furumoto and others, 1970; Kroenke, 1970).

Reflection profiles show that the central part of the Plateau is covered with a thick blanket of highly stratified sediment averaging between 0.6 seconds of reflection time on the eastern margin to over 1.1 seconds near the center of the Plateau. Wide-angle reflection-refraction measurements reported by Maynard and others (1969), Sutton and others (1969) and Maynard (1970) indicate that velocities of 1.7, 2.1, 2.4 , and 3.0 to $3.8 \mathrm{~km} / \mathrm{sec}$ consistently characterize the sedimentary column. The track of the Glomar Challenger crossed the Plateau immediately north of a broad bathymetric dome in the area of the thickest plateau sediment. Cores obtained at Site $64\left(1^{\circ} 44^{\prime} \mathrm{S}\right.$, $158^{\circ} 36^{\prime} \mathrm{E}$ ) show that the sediment on the Ontong Java Plateau is composed of nannofossil chalk ooze grading through chalk to limestone and cherty limestone. Drilling on the Plateau was terminated at 985 meters in Middle Eocene chert. The chert horizon appears to correlate well with the variable 3.0 to $3.8 \mathrm{~km} / \mathrm{sec}$ layer observed in the wide-angle reflection-refraction data, and is traceable in the reflection profiles over most of the Plateau.

Measurements of crustal velocity and depth parameters also discussed by Maynard (1970) indicate a velocity of $5.6 \mathrm{~km} / \mathrm{sec}$ for the upper oceanic crust underlain by material with a velocity of $6.5 \mathrm{~km} / \mathrm{sec}$. Furumoto and others (1970) have reported a total crustal thickness in excess of 25 kilometers for the southeastern portion of the Plateau. Donald Hussong (personal communication) has stated that, from field determinations in mid-1970, the curst of the central and northwestern part of the Plateau is considerably thicker.

Relection profiles taken across the Plateau show that reflectors within the carbonate sequence can be traced laterally for great distances. There are again suggestions that the individual reflectors are everywhere synchronous, as indicated by agreement in closure along survey loops (that is, correlating reflectors through the network of intersecting ship's tracks). Certainly the acoustic character of the reflectors changes very little, if at all, with lateral extent, indicating that a similar lithologic sequence is present over most of the Ontong Java Plateau.

Two prominent lower reflectors are almost always observed in the reflection profiles over the Plateau. The first, as was mentioned earlier, is the chert or the 3.0 to $3.8 \mathrm{~km} / \mathrm{sec}$ layer, whereas the second is the top of the $5.6 \mathrm{~km} / \mathrm{sec}$ layer, which is interpreted as basaltic basement. Commonly, weak reflections are observed below the lower of these two prominent reflectors. The weak, deep reflectors often exhibit considerable relief-suggestive of a rugged paleotopography which may have been smoothed by later emanations of basalt, possibly accumulating in a manner similar to that of continental plateau of flood basalts.

The track of the Glomar Challenger obliquely crossed the mouth of one of the large submarine valleys that characterize the northeast edge of the Plateau, and in which basement appears to be exposed. At $0^{\circ} 27^{\prime} \mathrm{S}$, $162^{\circ} 07^{\prime} \mathrm{E}$, the track crossed the boundary between the Ontong Java Plateau and the Nauru Basin.

\section{NAURU BASIN}

The Nauru Basin is bounded to the north by the Marshall Abyssal Plain, to the east by the Gilbert Ridge, and to the south and west by the Ontong Java Plateau. The track of the Glomar Challenger, en route to Site 65 , crossed the central part of the Basin north of Nauru Island. The transition from the sediments of the plateau province to those of the Nauru Basin is described elsewhere and consists of: an erosional thinning of the northeastern plateau sequence within a large submarine valley; a series of exposed basement steps; and finally, over a slight basement step an abrupt change to the transparent sediments typical of the deep, central-equatorial Pacific. Similarity in reflection character of these sediments with the transparent sediments of the Central Pacific Basin is suggestive of a similar lithology, that is, radiolarian ooze. 


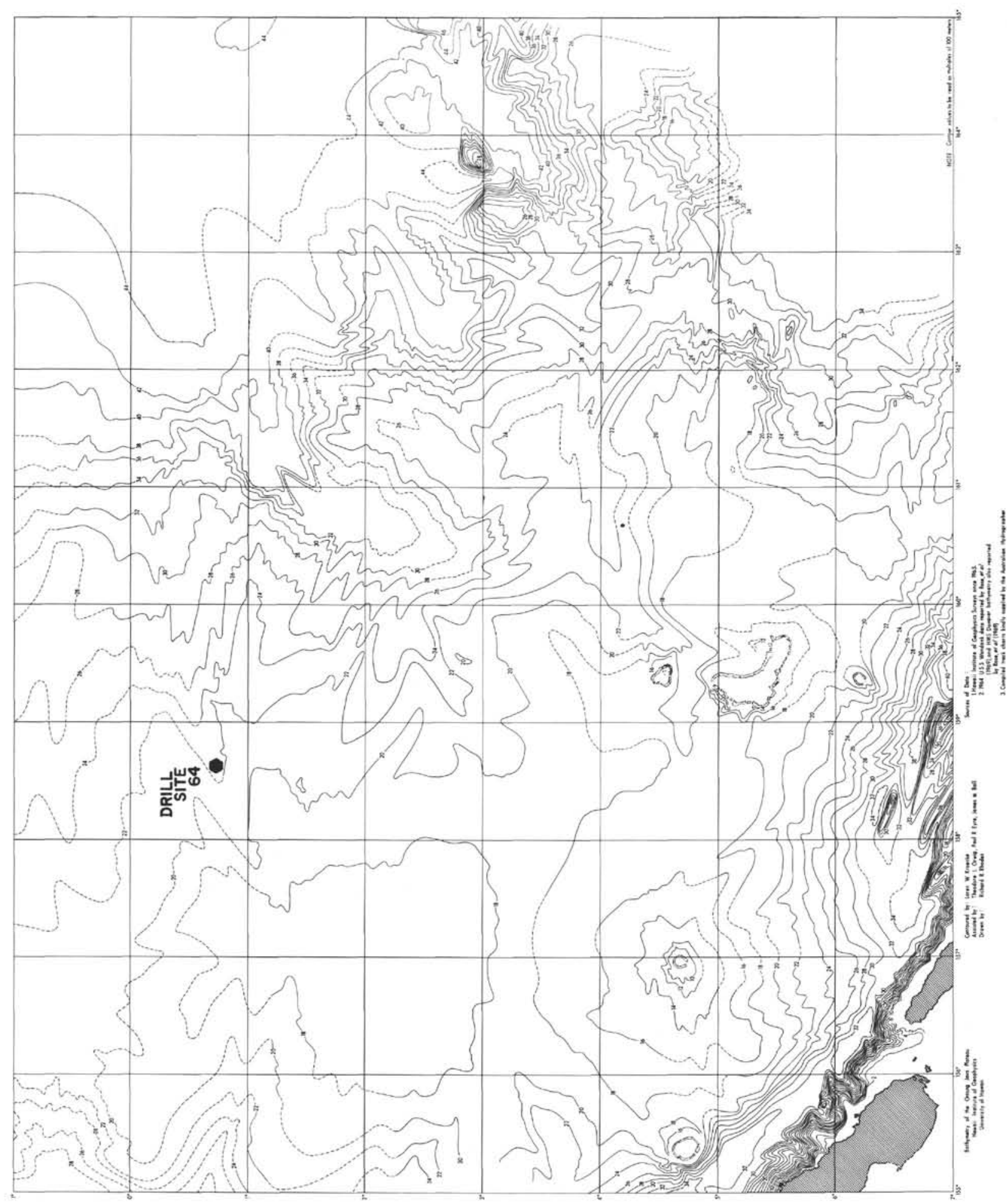

Figure 4. Bathymetry of the northeastern half of the Ontong Java Plateau. Contour interval 200 meters, uncorrected for changes in the velocity of sound in sea water. 
The transparent sediments extend along the track of the Glomar Challenger as far as $0^{\circ} 07^{\prime} \mathrm{N}, 163^{\circ} 52^{\prime} \mathrm{E}$ where a diffusely reflective zone pervades the transparent layer. This medial amorphous zone, which grades laterally into discrete reflectors over a distance of 100 kilometers along the track, is thought to indicate change from a relatively pure radiolarian ooze to a more carbonate-rich facies. The transitional facies may represent the extremity of turbidity current deposition from currents that originated from either the Ontong Java Plateau about 330 kilometers to the south and to the west or the Gilbert Ridge over 900 kilometers to the east. There are, in addition, a few more obvious but small turbidite plains in the eastern part of the Nauru Basin. They are commonly near local uplifts and are present nearly as far east as the border of the Central Pacific Basin.

The sediments of the Nauru Basin vary somewhat in thickness laterally but in general they thicken to the east-northeast as the Gilbert Ridge is approached. The column increases in thickness from less than 150 meters where first encountered at the southwestern edge of the Basin to more than 1000 meters near the Gilbert Ridge. Because the sediments of the eastern half of the basin are so thick, so well-stratified, and have the reflective characteristics of carbonate sections observed elsewhere, it can be speculated that they probably are carbonates.

Tectonic inferences may also be drawn from the foregoing discussion. The manner in which the sediments thicken in the eastern half of the basin, together with the regional configuration of the basement relief and that of the overlying structure, suggests subsidence of the eastern half of the Nauru Basin. If the inference from the reflection profile is correct, it would appear that the subsidence, accompanied by mild tilting to the east, occurred after the cessation of volcanic activity on the Gilbert Ridge.

\section{GILBERT RIDGE}

A linear group of more or less discrete volcanic seamounts and coral atolls forms the Gilbert Ridge which rests on the eastern margin of the Nauru Basin. North of the Gilbert Ridge lies the Radak Ridge of the Marshall Islands and to the south, the atolls of the Ellice group. The track of the Glomar Challenger crossed the Gilbert Ridge just south of Makin Atoll.

A small turbidite plain lies in a depression formed against the west insular flank. The depression at the top of the thick well-stratified, probably carbonate section, may well have formed during the tilting of the Nauru Basin, possibly as a result of crustal loading by the Gilbert Ridge itself.
To the east the section lies slightly crumpled over the insular slope, farther east it is less deformed, until rather abruptly, the upper part of the section is truncated. Farther along the track the section varies in lithology and relief. The first poorly-reflective, acoustically-transparent sediments, representative of the Central Pacific Basin, are observed to overlie the thicker stratified section about 140 kilometers east of Makin Atoll. Both the transparent layer and the stratified layer vary in thickness eastward, to the edge of an escarpment which marks the western boundary of the Central Pacific Basin.

\section{CENTRAL PACIFIC BASIN}

The central Pacific region forms a very deep basin, bounded on the east by the Line Islands and on the west by the Radak and Gilbert Ridges. To the north lie the Mid-Pacific Mountains described by Hamilton (1956) whereas to the south are found the islands of the Tokelau group together with the Manahiki Plateau (Heezen et al., 1966). Within this basin Sites 65 and 66 were drilled.

Water depth in the Central Pacific Basin, in general, is greater than 5000 meters, commonly reaching depths of over 6000 meters. Along the track of the Glomar Challenger, depths greater than 6000 meters were encountered only in the vicinity of Site 65 east of the Gilbert Ridge. However, Menard (1967) has reported great depths elsewhere in the region, usually in troughs associated with fractured zones which are thought to extend into, if not through, the region.

Reflection profiles taken along the track of the Glomar Challenger across the Central Basin show a remarkable constancy. The section is represented for the most part by a very poorly-reflective, unstratified, transparent layer variable in thickness but generally ranging from 150 to 250 meters thick, overlying a thinner opaque layer which in turn rests on acoustic basement. These layers were described by Ewing and others (1968).

The transparent layer changes laterally and almost predictably with elevation. Toward the center of the Basin, along the track of the Glomar Challenger, the section appears to become more reflective (less transparent) wherever the sea floor rises above 5150 meters, becoming well stratified in depths less than 5000 meters. The section returns to the unstratified, almost invisible, condition in the profiles where the ocean floor drops back to depths in excess of 5150 meters. The unstratified transparent section was cored at both Sites 65 and 66 and was found to be Radiolarian ooze. The evidence from piston and gravity cores suggests that it is of the same dominantly radiolarian composition wherever observed in the Central Basin. The slight degree of stratification in the records from Gilbert Ridge to Site 65 almost certainly are turbidites like the 
few cored at Site 65 (Heath and Moberly, this volume). On the other hand, gradation from the unstratified condition to the stratified state in the central part of the Basin is postulated to be the result of increasing carbonate content above the depth of total carbonate solution.

The opaque layer, observed to underlie the transparent section over most of the Central Basin, was cored at Site 66 and found to be brown clay overlain by multiple, thin beds of Middle Eocene porcelanite. At Site 65 , at about the same stratigraphic position, drilling difficulties were encountered at the top of the opaque layer. Chert fragments recovered from that level suggest a section similar to that at Site 66. It is possible that the opaque sequence may also represent a basin-wide uniform lithology of Cretaceous brown clays overlain by thinly-bedded Eocene cherts. Acoustic basement is basalt at Site 66 , and probably is basalt throughout the Basin.

Faulting and relative uplife of the basaltic basement, together with local volcanism, are thought to be responsible for the numerous abyssal hills dotting the region and commonly appearing in the profiles taken by the Glomar Challenger and other ships. The transparent horizon or radiolarian ooze is observed deposited about the hills in various stratigraphic attitudes. In some places it pinches out at the base of the hills whereas in other places it overlies the hills conformably. These observations suggest that bottom currents control the accumulation of the ooze in the vicinity of the abyssal hills, as was demonstrated by Johnson and Johnson (1970) in a similar area south of the Line Islands Ridge.

Turbidite deposits found on both the eastern and western margins of the Basin commonly are present in association with seamounts and other local elevated areas. The turbidites of the eastern margin differ from those on the western margin and exhibit an unusual morphology in the reflection profiles. West of the Line Islands, abrupt vertical discontinuities are observed in the records between the transparent section that is more or less conformable with underlying topography, and the adjoining, flat-lying, highly-stratified sections. Reflection records and cores from cruises both before and after Leg 7 reveal that the stratified deposits are calcareous ooze and commonly are at lower elevations than the surrounding siliceous ooze. These observations suggest that the calcareous sediment accumulated in channels and small basins from density currents flowing out from the higher elevations of the Line Island Ridge and Seamount Province. The near-vertical boundaries of the turbidite bodies suggest that they aggraded during a long period of time through fixed channels that formed a relatively permanent submarine distributary system (Woollard and others, 1970).

\section{LINE ISLANDS RIDGE AND SEAMOUNT PROVINCE, UNNAMED BASIN SOUTH OF HAWAIIAN ISLANDS, HAWAIIAN RIDGE, HAWAIIAN ARCH}

The Glomar Challenger steamed at higher speeds across these provinces and the quality of the records was not as good as those obtained earlier. For three of the provinces there was no drilling by Leg 7 crews, and the information obtained at Site 67, on the Hawaiian Arch, was meager. Observations and speculations listed in Table 2 for these provinces are therefore based mainly on the work of others (Woollard et al., 1970; Ewing et al., 1968; Sutton et al., 1970; Heath and Moore, 1965; Moore and Heath, 1967; Kroenke, 1965; Woolard, 1965; Normark and Shor, 1968).

\section{REFERENCES}

Ewing, J., Ewing, M., Aitken, T. and Ludwig, W. J., 1968. North Pacific sediment layers measured by seismic profiling. In "The Crust and Upper Mantle of the Pacific Area" L. Knopoff, C. L. Drake, and P. J. Hart, (Eds.) Am. Geophys. Union, Monograph 12. $522 \mathrm{p}$.

Ewing, J., Windisch, C. and Ewing, M., 1970. Correlation of Horizon A with Joides bore-hole results. $J$. Geophys. Res. 75, 5645 .

Ewing, J., Worzel, J. L., Ewing, M. and Windisch, C., 1966. Ages of Horizon A and the oldest Atlantic sediments. Science. 154, 1125.

Field, R. M., 1933. The Principles of Historical Geology from a Regional Point of View. Princeton (Princeton University Press), $283 \mathrm{p}$.

Fischer, A. G., Heezen, B. C., Boyce, R. E., Bukry, D., Douglas, R. G., Garrison, R. E., Kling, S. A., Krasheninnikov, V., Lisitzin, A. P. and Pimm, A. C., 1970. Geological history of the western North Pacific. Science. 168, 1210.

Furumoto, A. S., Hussong, D. M., Campbell, J. F., Sutton, G. H., Malahoff, A., Rose, J. C. and Woollard, G. P., 1970. Crustal and upper mantle structure of the Solomon Islands as revealed by seismic refraction survey of November-December 1966. Pacific Sci. 24, 315.

Gartner, S., Jr., 1970. Sea-floor spreading, carbonate dissolution level, and the nature of Horizon A. Science. 169, 1077.

Heath, G. R. and Moberly, R., Jr., 1971. Turbidites. In Winterer, E. L., et al., 1971. Initial Reports of the Deep Sea Drilling Project, Volume VII. Washington (U. S. Government Printing Office.

Heath, G. R. and Moore, T. C., 1965. Subbottom profile of abyssal sediments in the central equatorial Pacific. Science. 149, 744.

Hamilton, E. L., 1956. Sunken islands of the MidPacific Mountains. Geol. Soc. Am. Memoir 64. 97 p.

Heezen, B. C., Glass, B. and Menard, H. W., 1966. The Manihiki Plateau. Deep Sea Res. 13, 445. 
Hersey, J. B., 1963. Continuous reflection profiling. In Hill, M. N. (Ed.) The Sea. New York (Interscience) $3,963 \mathrm{p}$.

Hess, H. H., 1948. Major structural features of the western North Pacific. Bull. Geol. Soc. Am. 59, 417.

Johnson, D. A. and Johnson, T. C., 1970. Sediment redistribution by bottom currents in the Central Pacific. Deep-Sea Res. 17, 157.

Kroenke, L. W., 1965. Seismic reflection studies of sediment thickness around the Hawaiian Ridge. Pacific Sci. 19, 335.

Kroenke, L. W., 1970. Geological investigations of the Ontong Java Plateau. Unpublished manuscript.

Maynard, G. L., 1970. Crustal layer of seismic velocity 6.9 to 7.6 kilometers per second under the deep oceans. Science. 168, 120.

Maynard, G. L., Sutton, G. H. and Hussong, D. M., 1969. Seismic observations in the Solomon Islands and Darwin Rise regions using repetitive sources (Abstract). Trans. Am. Geophys. Union. 50, 206.

Menard, H. W., 1964. Marine Geology of the Pacific. New York (McGraw-Hill), 271 p.

Menard, H. W., 1967. Extension of northeastern Pacific fracture zones. Science. 155, 72 .

Moore, T. C., Jr. and Heath, G. R., 1967. Abyssal hills in the central equatorial Pacific: detailed structure of the sea floor and subbottom reflectors. Marine Geol. 5, 161.

Normark, W. R. and Shor, G. G., Jr., 1968. Seismic refraction study of the shallow structure of the Hawaiian Arch. J. Geophys. Res. 73, 6991.

Sutton, G. H., Maynard, G. L. and Hussong, D. M. 1969. Marine crustal seismic refraction studies using repetitive sources and sonobuoys (Abstract). Papers presented at Annual Meeting, Seis. Soc. Am., St. Louis, Mo. 15.

Sutton, G. H., Tracy, J. I., Jr., Beckman, J. P., Galehouse, J. S., Haq, U. Z. B., Lipps, J. H., Moore, T. C., Nesteroff, W. D. and von der Borch, C., 1970. Deep Sea Drilling Project, Leg 8. Geotimes. 15 (2), 14.

Woollard, G. P., 1965. Problems of the upper mantle and Hawaii as a site for the Moho hole. Pacific Sci. $19,271$.

Woollard, G. P., Furumoto, A. S., Sutton, G. H., Rose, J. C., Malahoff, A. and Kroenke, L. W., 1967. Cruise report on the 1966 seismic refraction expedition to the Solomon Sea. Hawaii Inst. Geophys. Rept. 67-3. $31 \mathrm{p}$.

Woollard, G. P., Sutton, G. H., Wyrtki, K. and Chave, K. E., 1970. Progress report, contract ONRN00014-70-A-0016-0001, for period 1 January31 July 1970. Haw. Inst. Geophys. Rept. 70.

\section{APPENDIX}

Here follow the seismic reflection profiles collected by Glomar Challenger during Leg 7. 

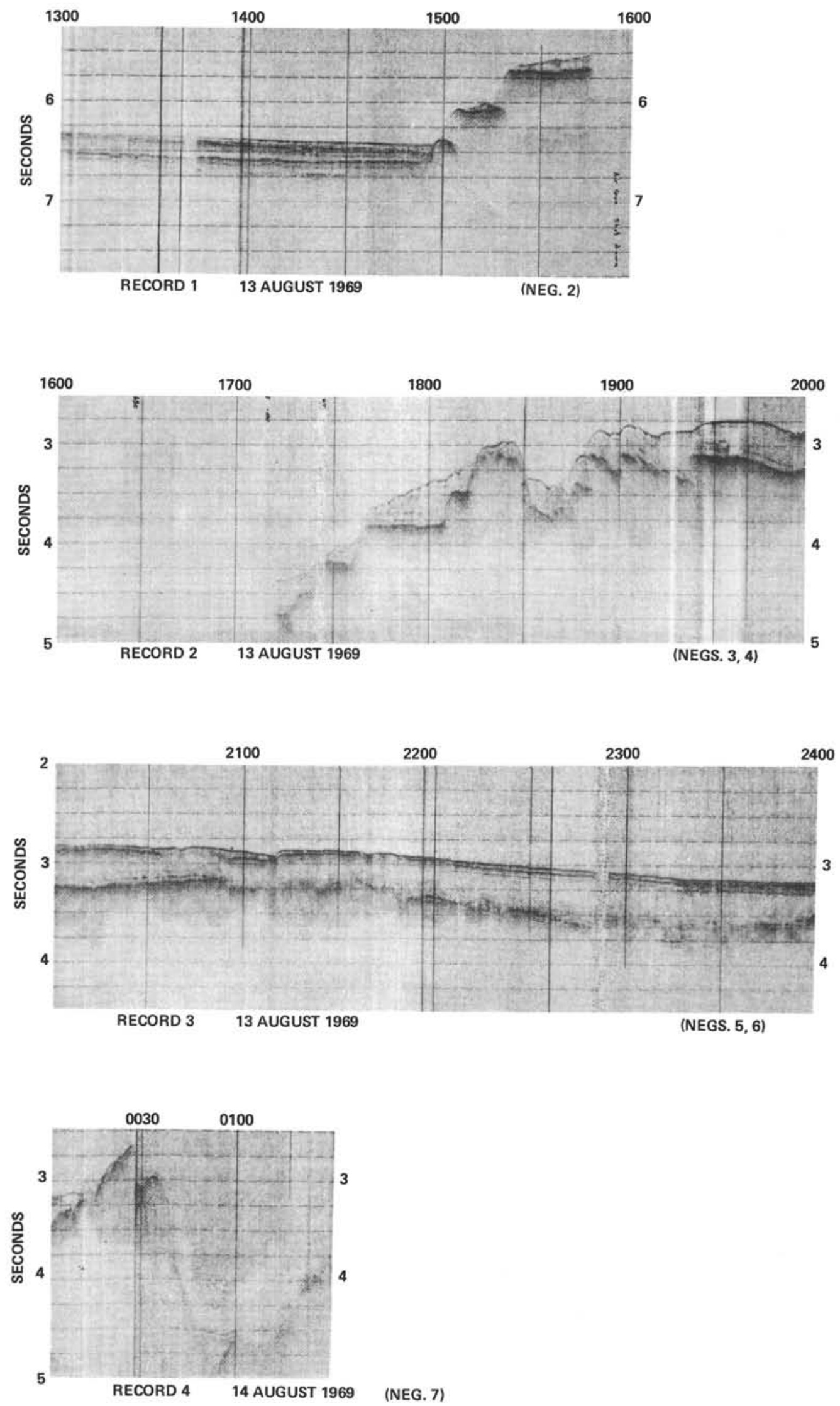

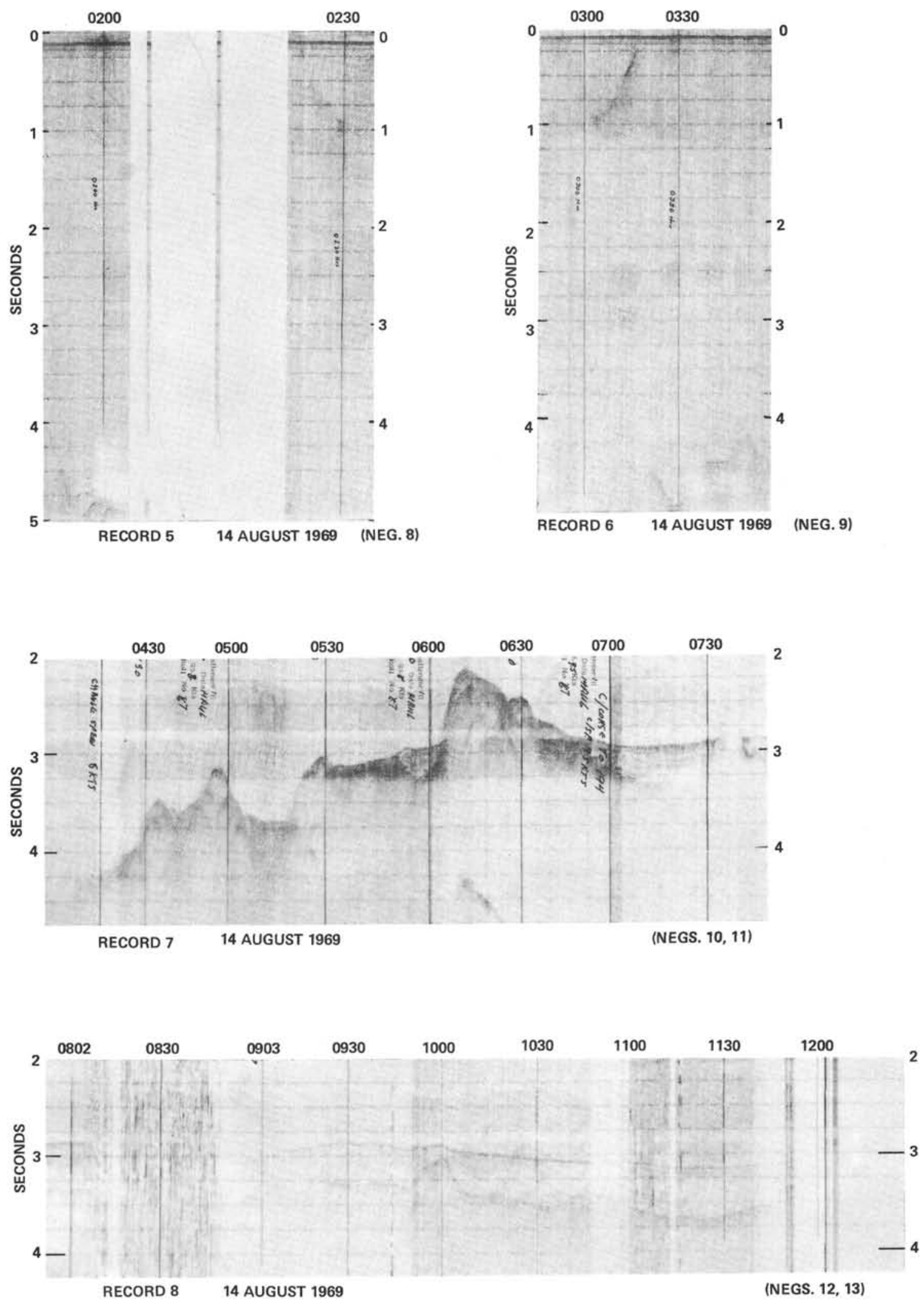

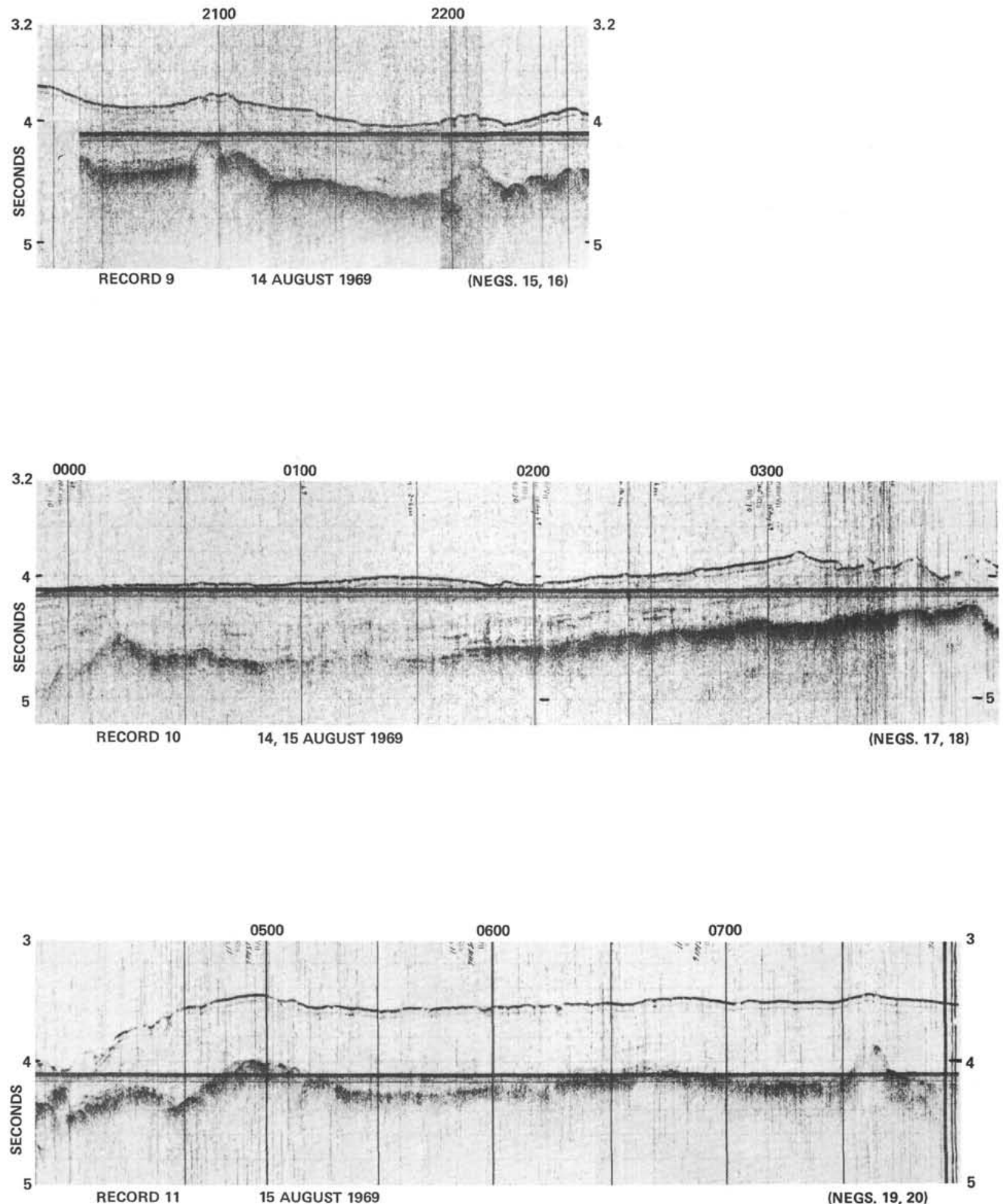

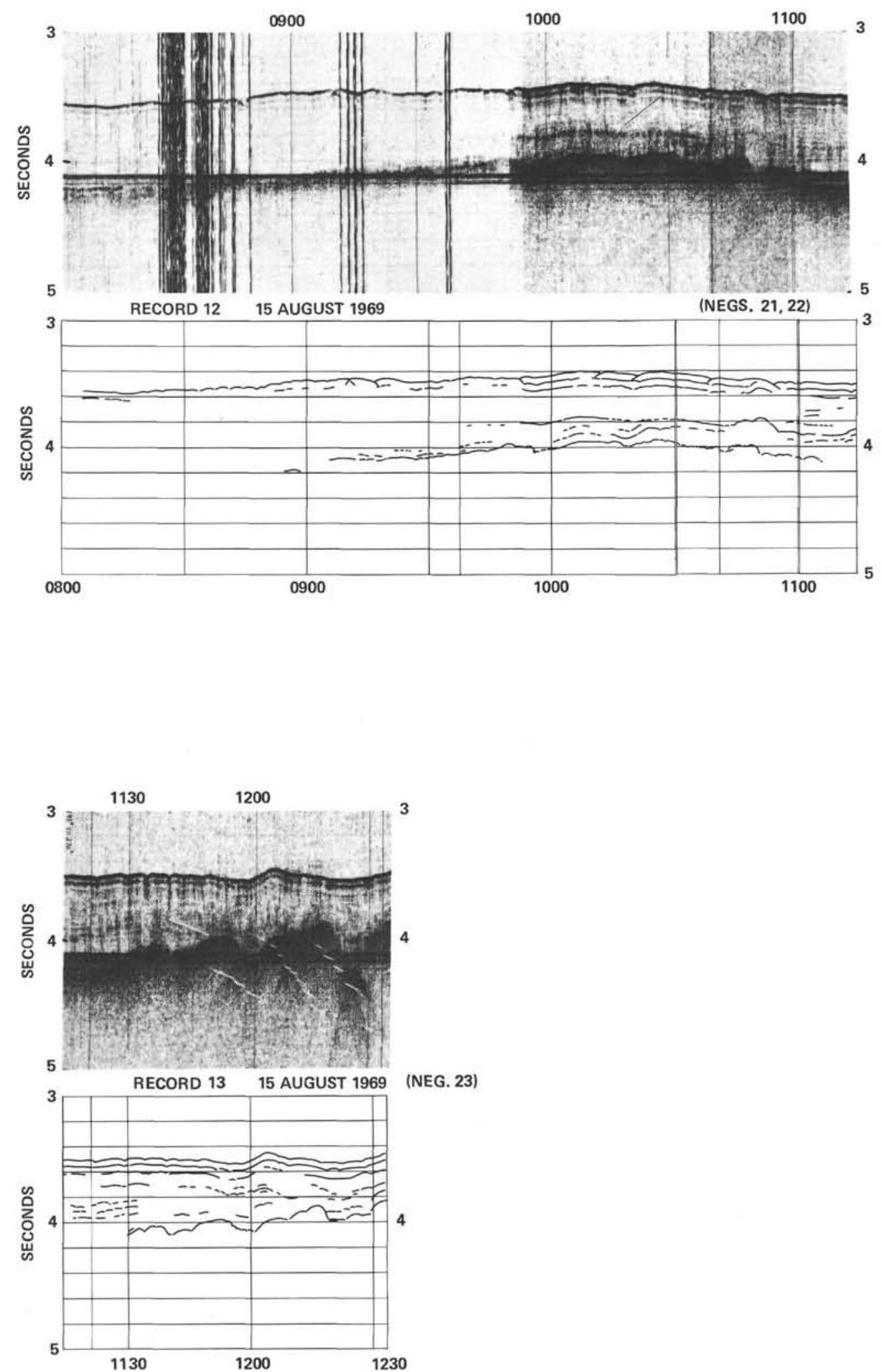

(NEG. 23) 

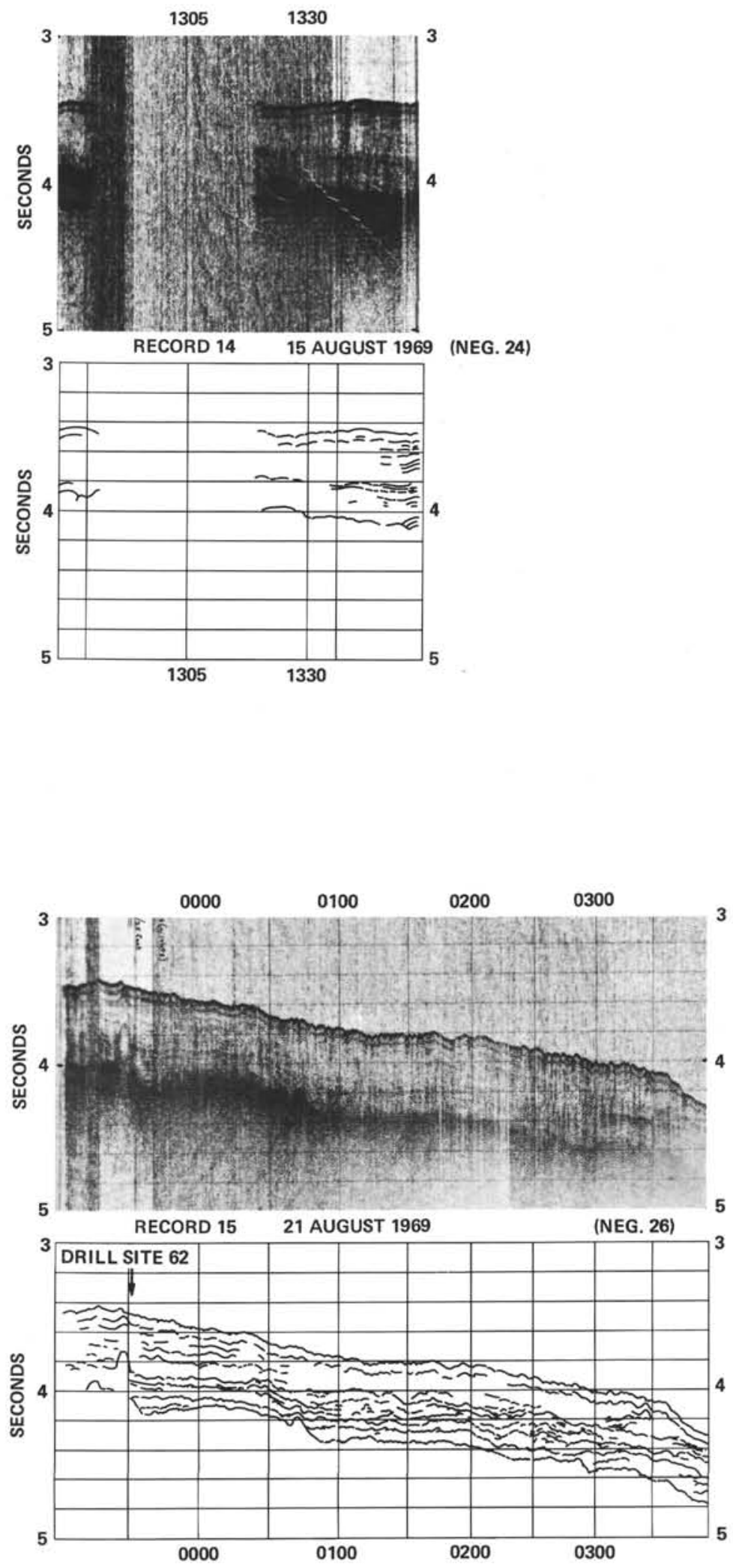

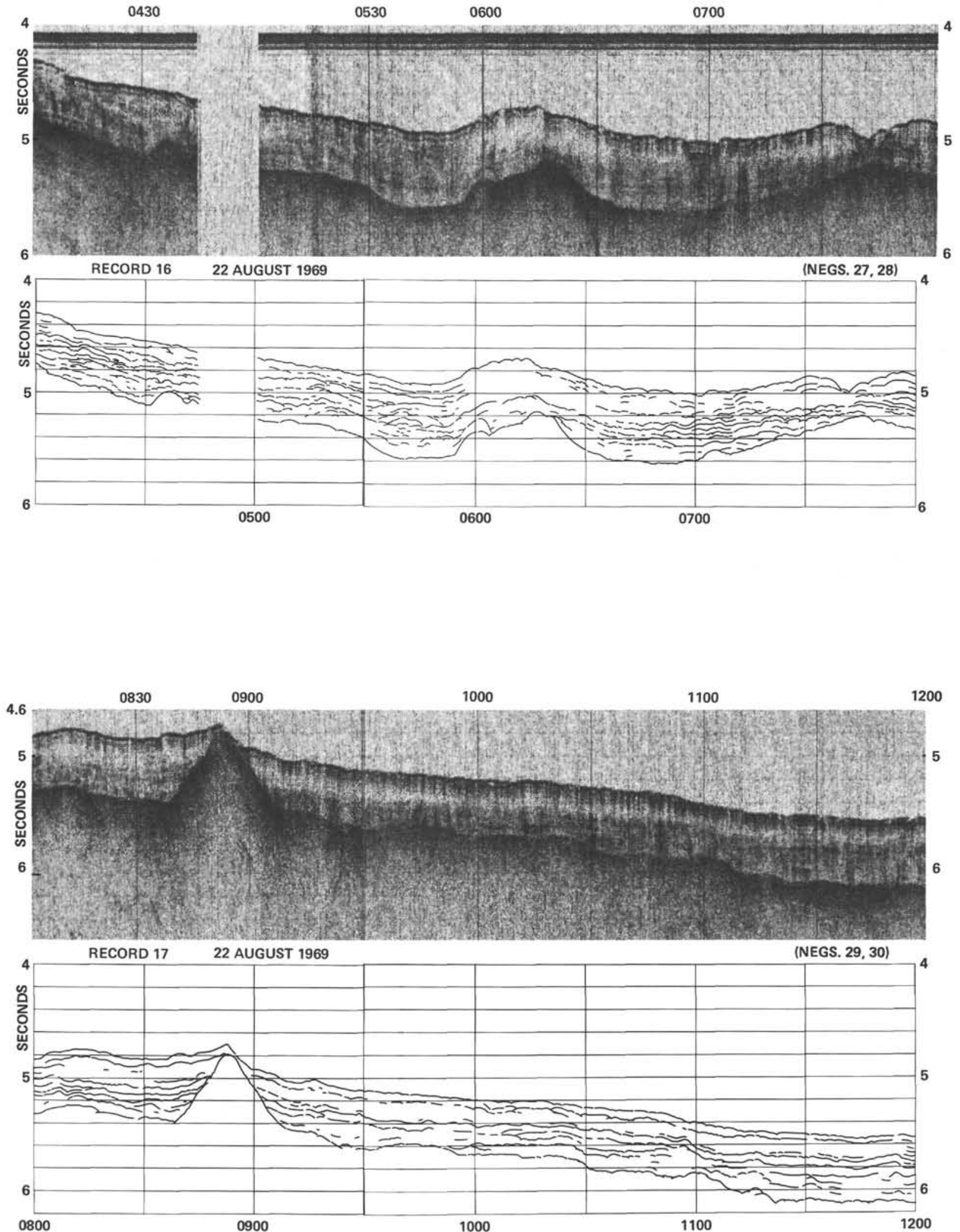

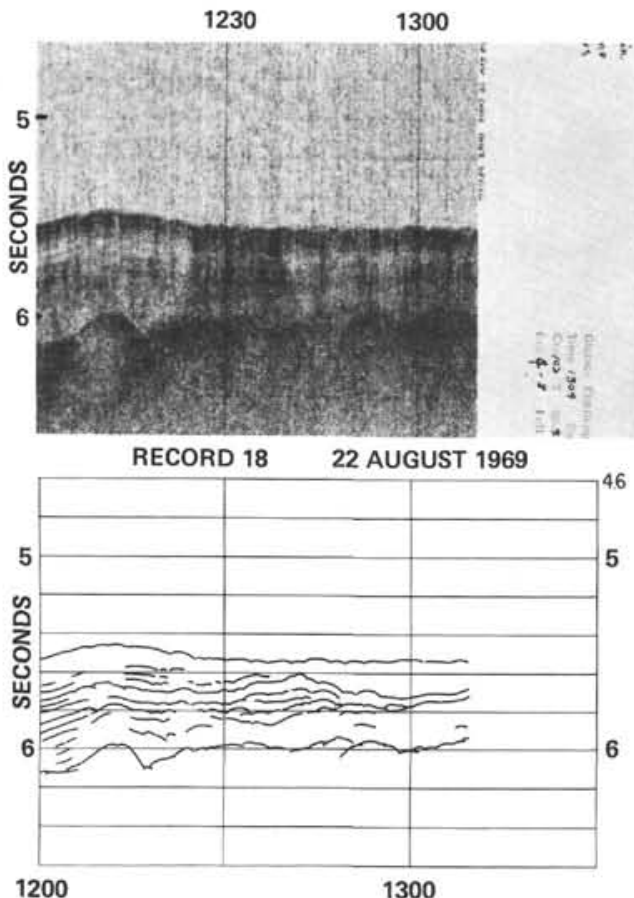

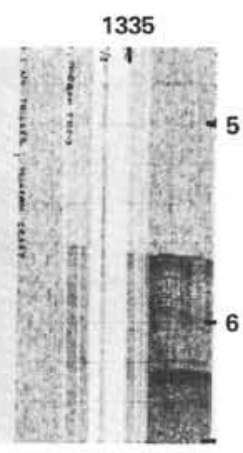

(NEG. 31)

1500

1600

1700

1800
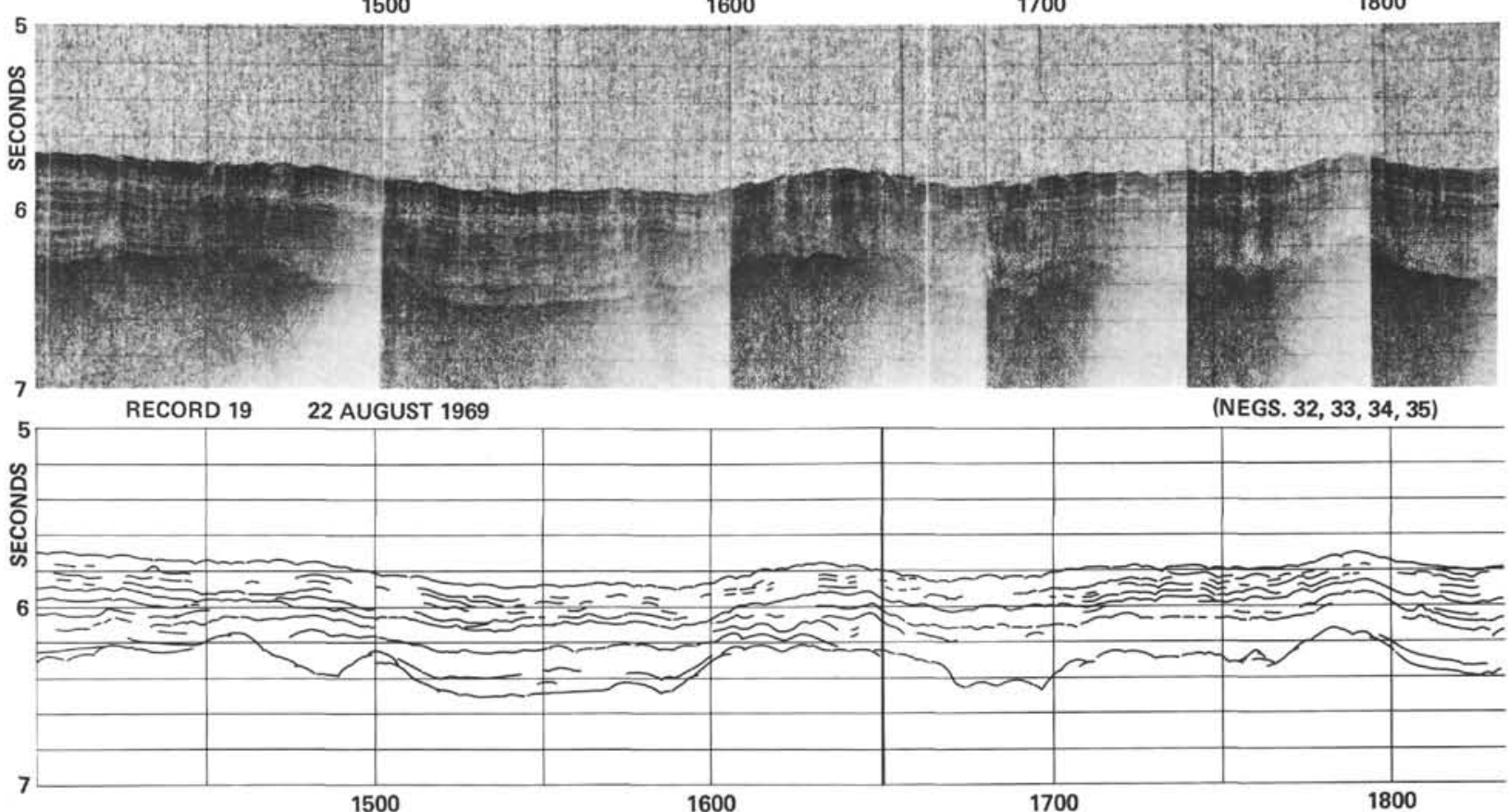

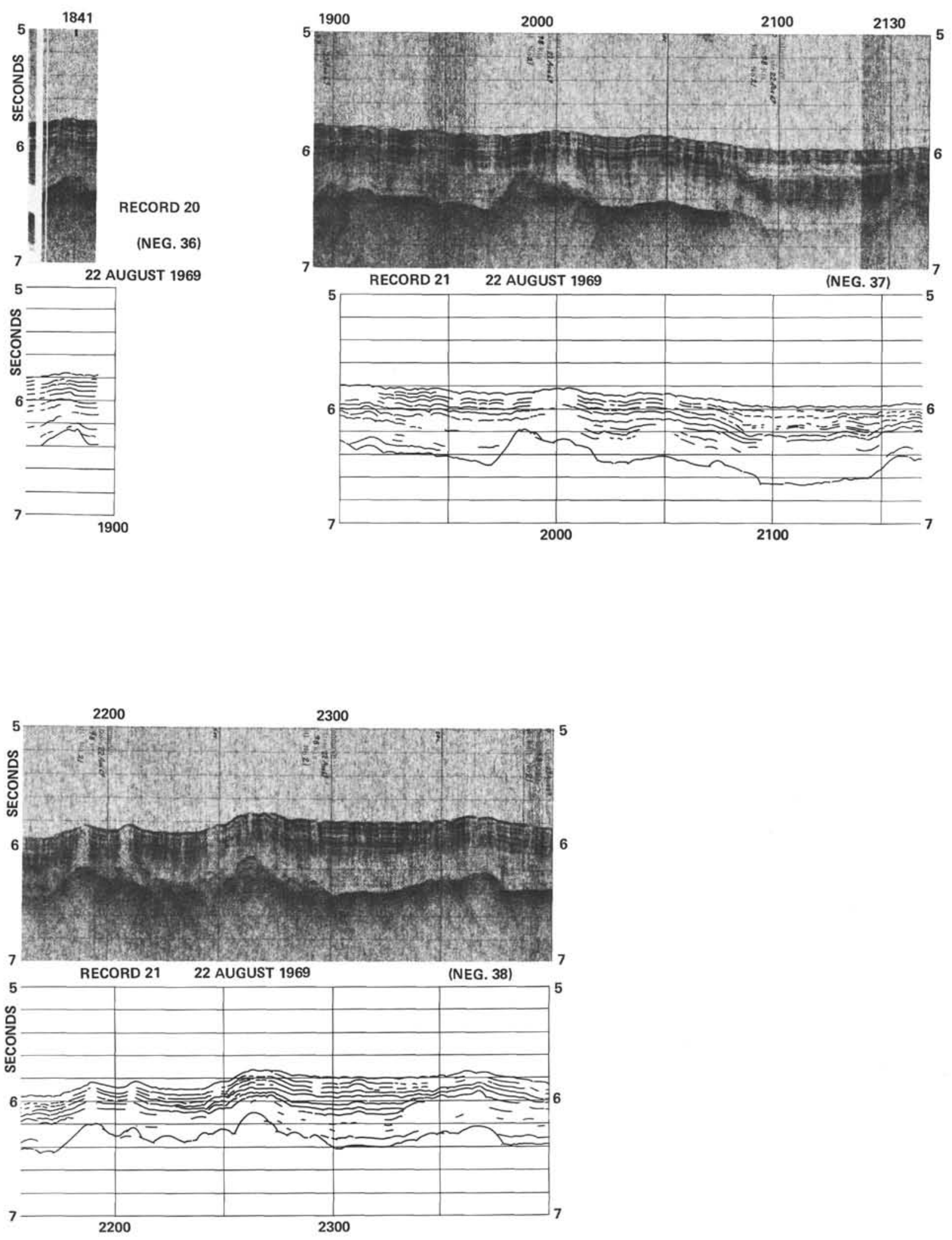

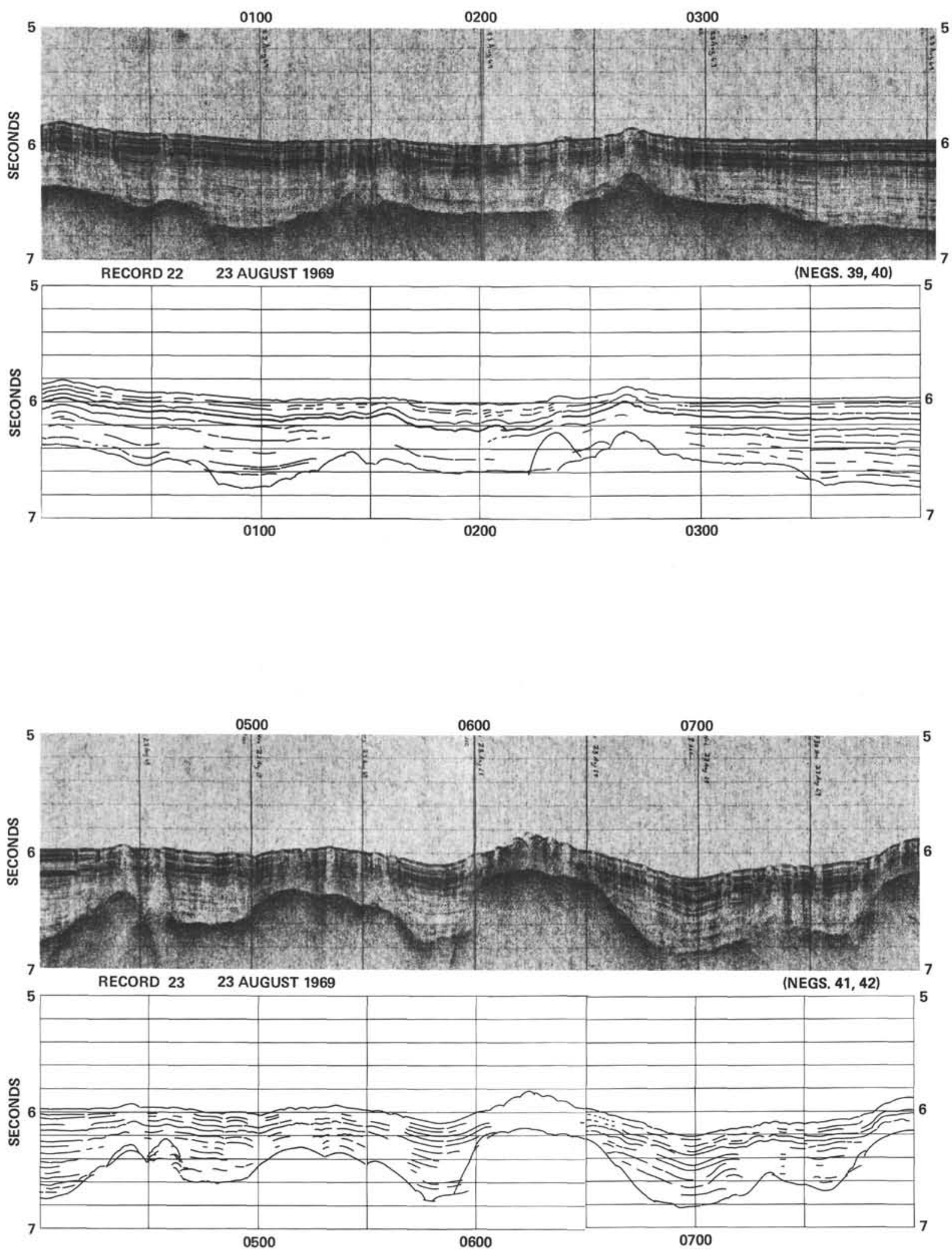

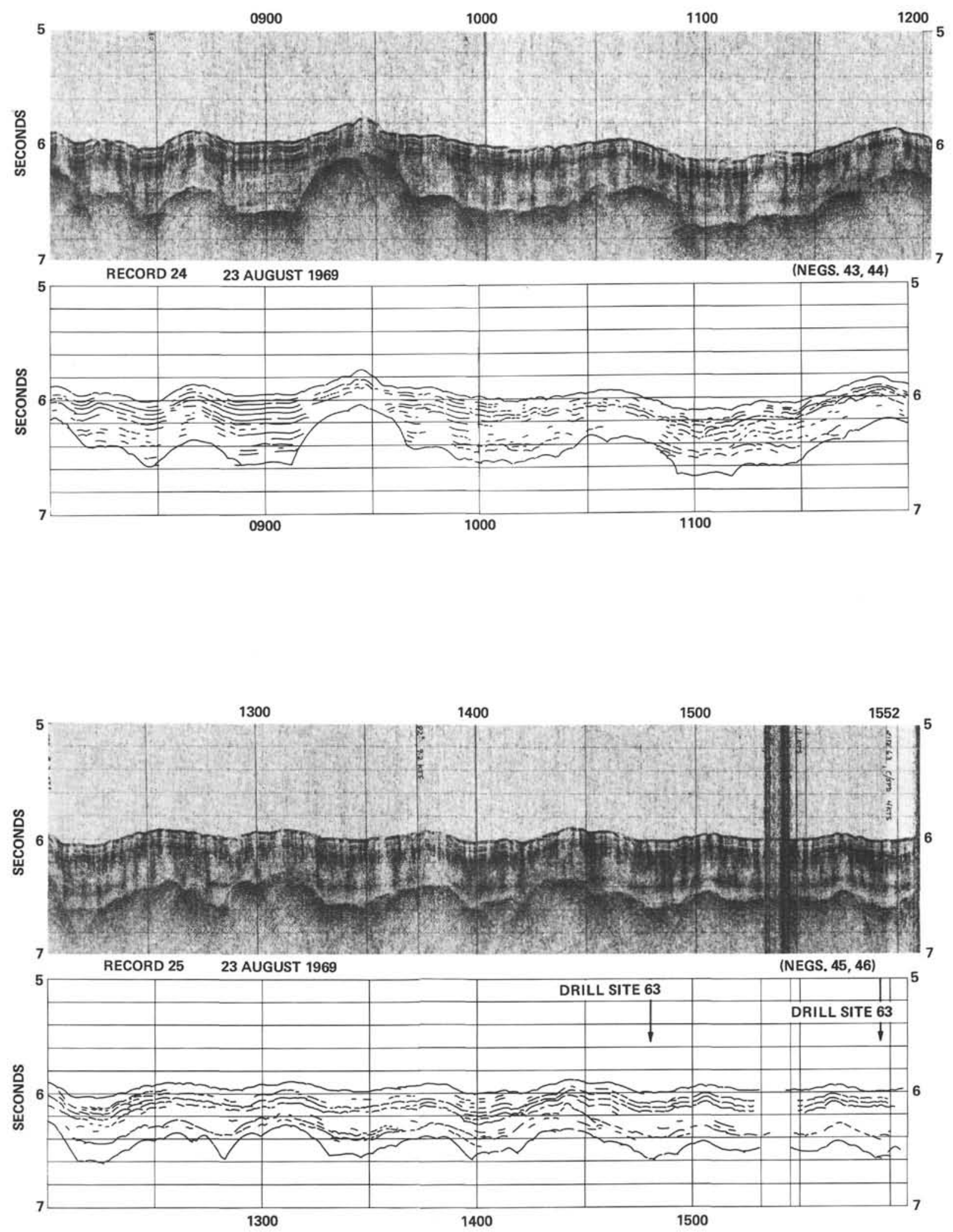

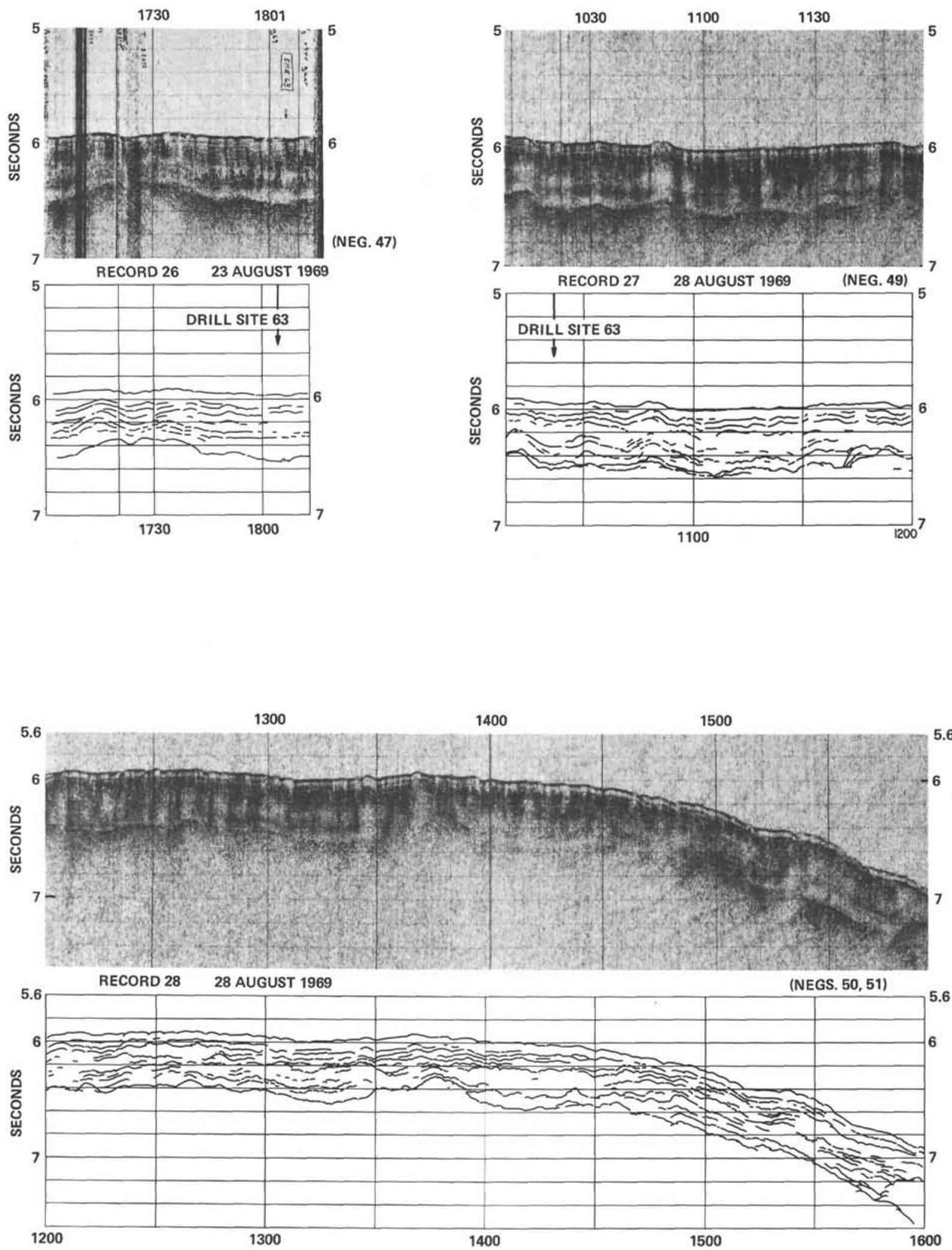

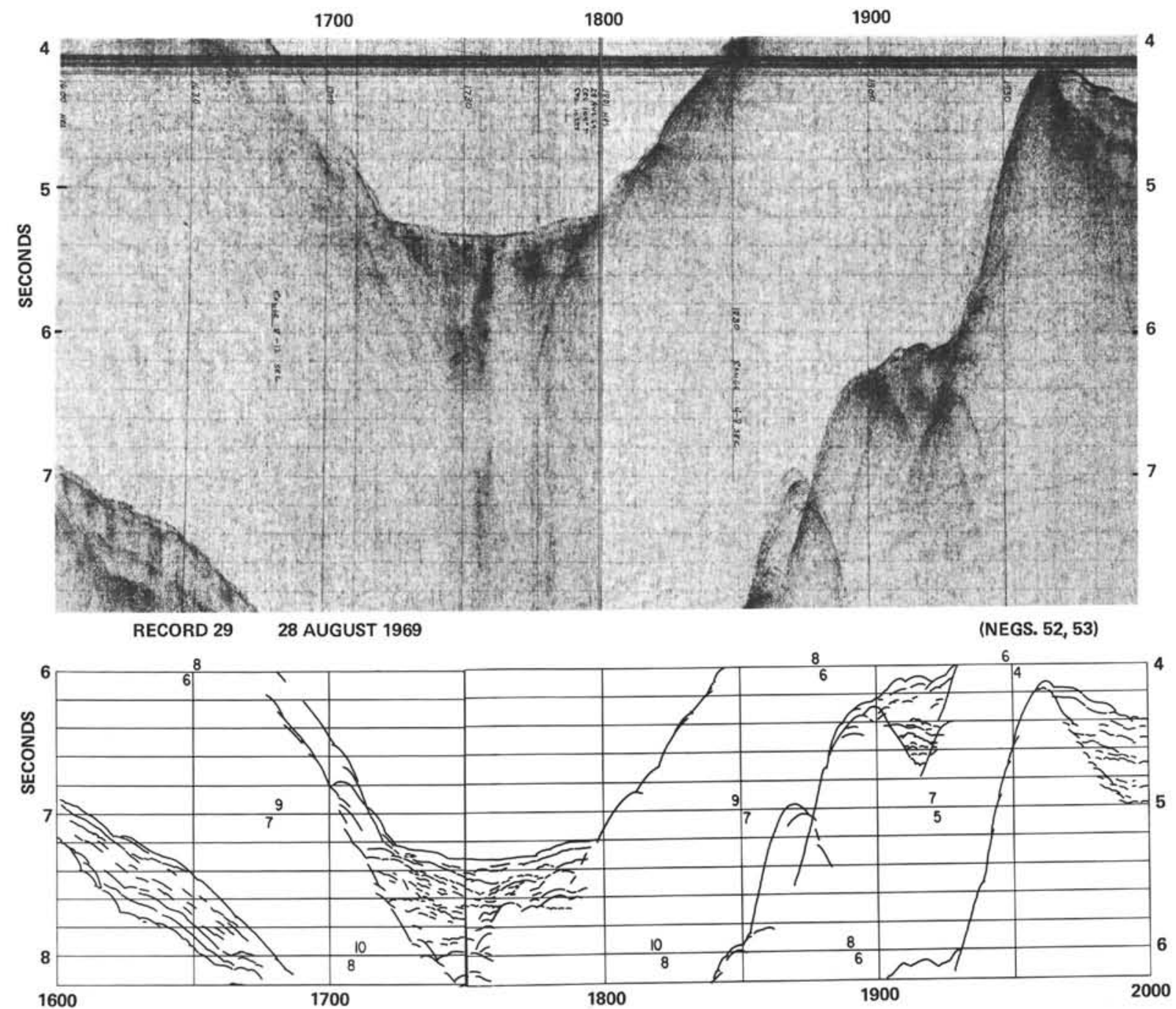

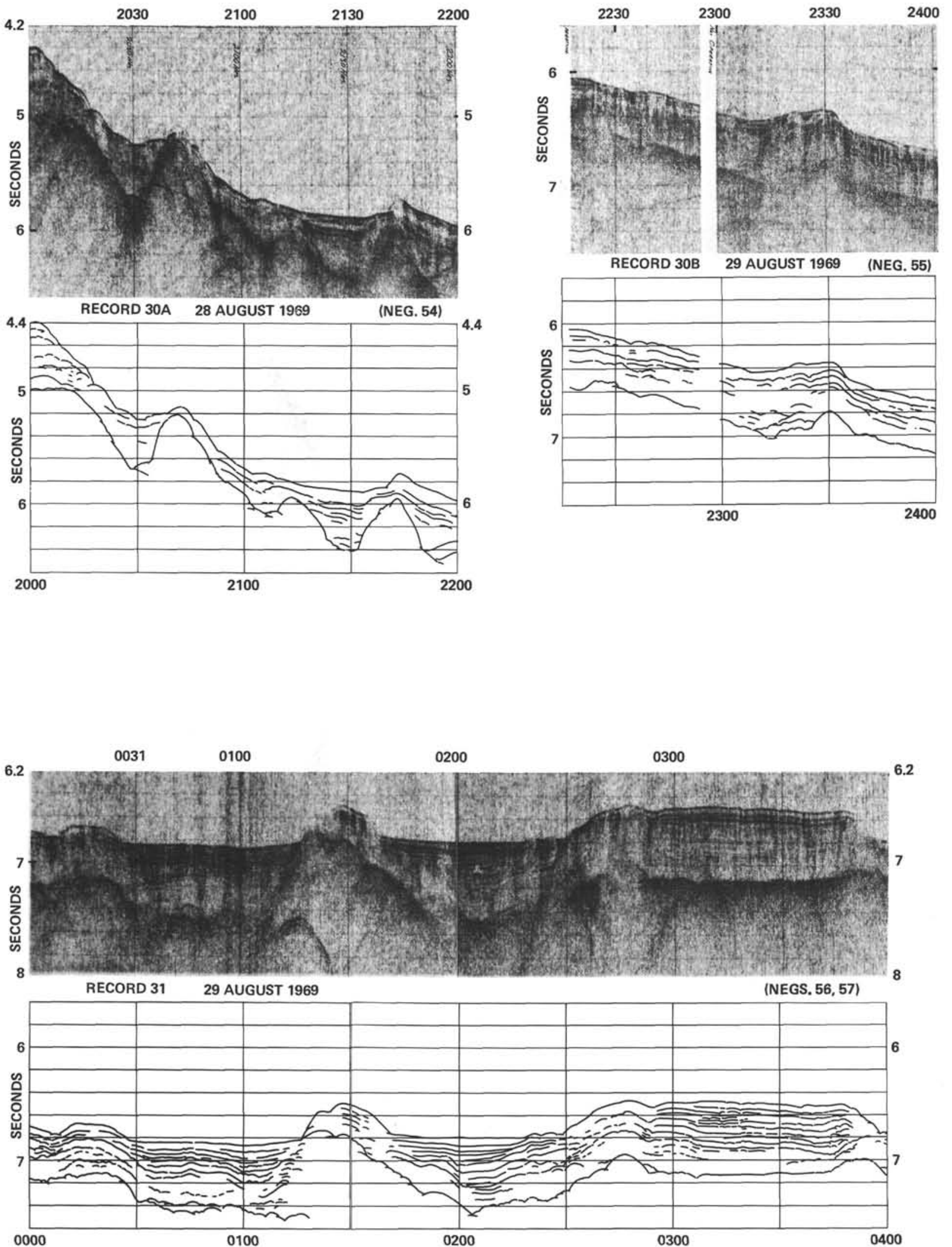

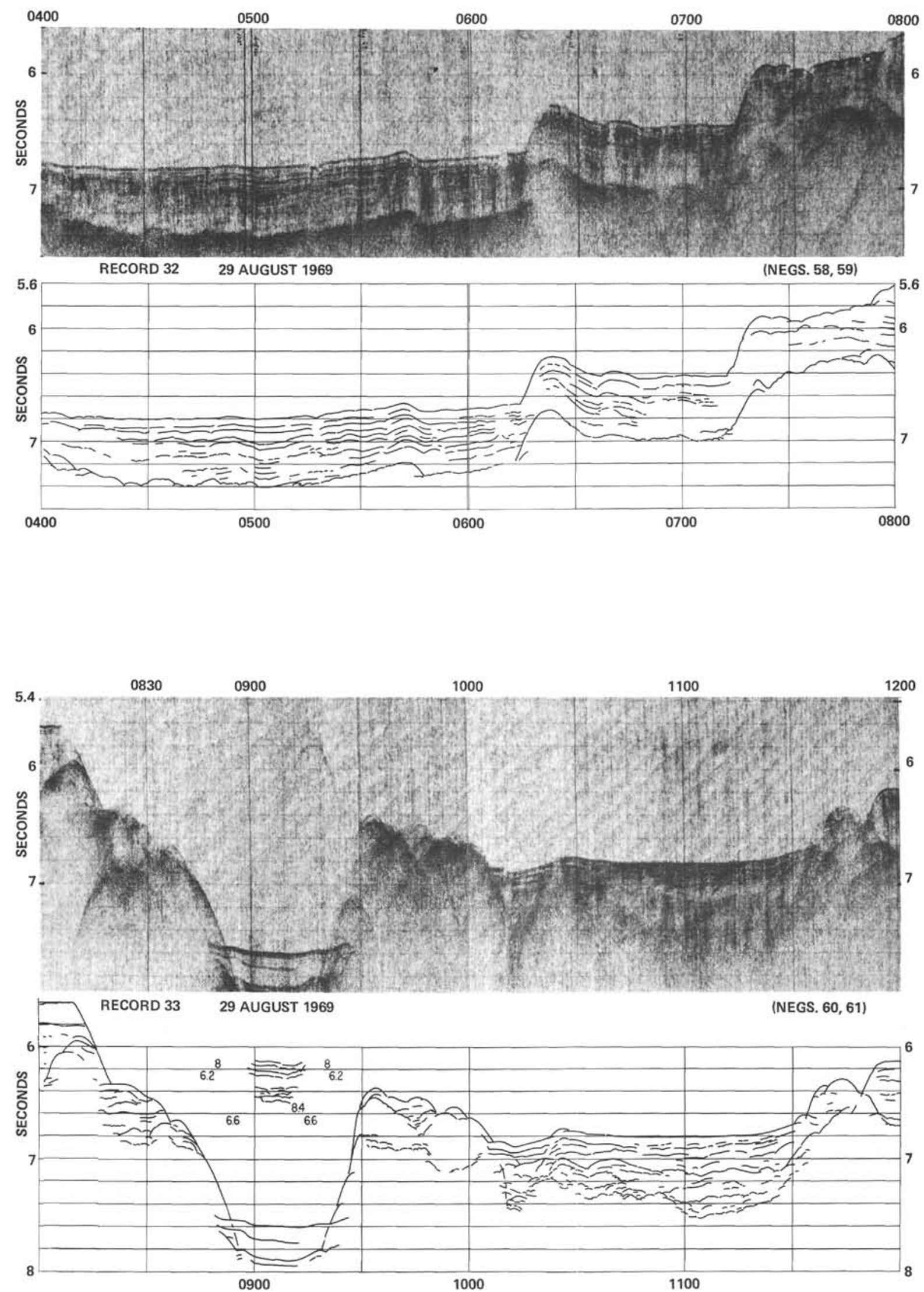

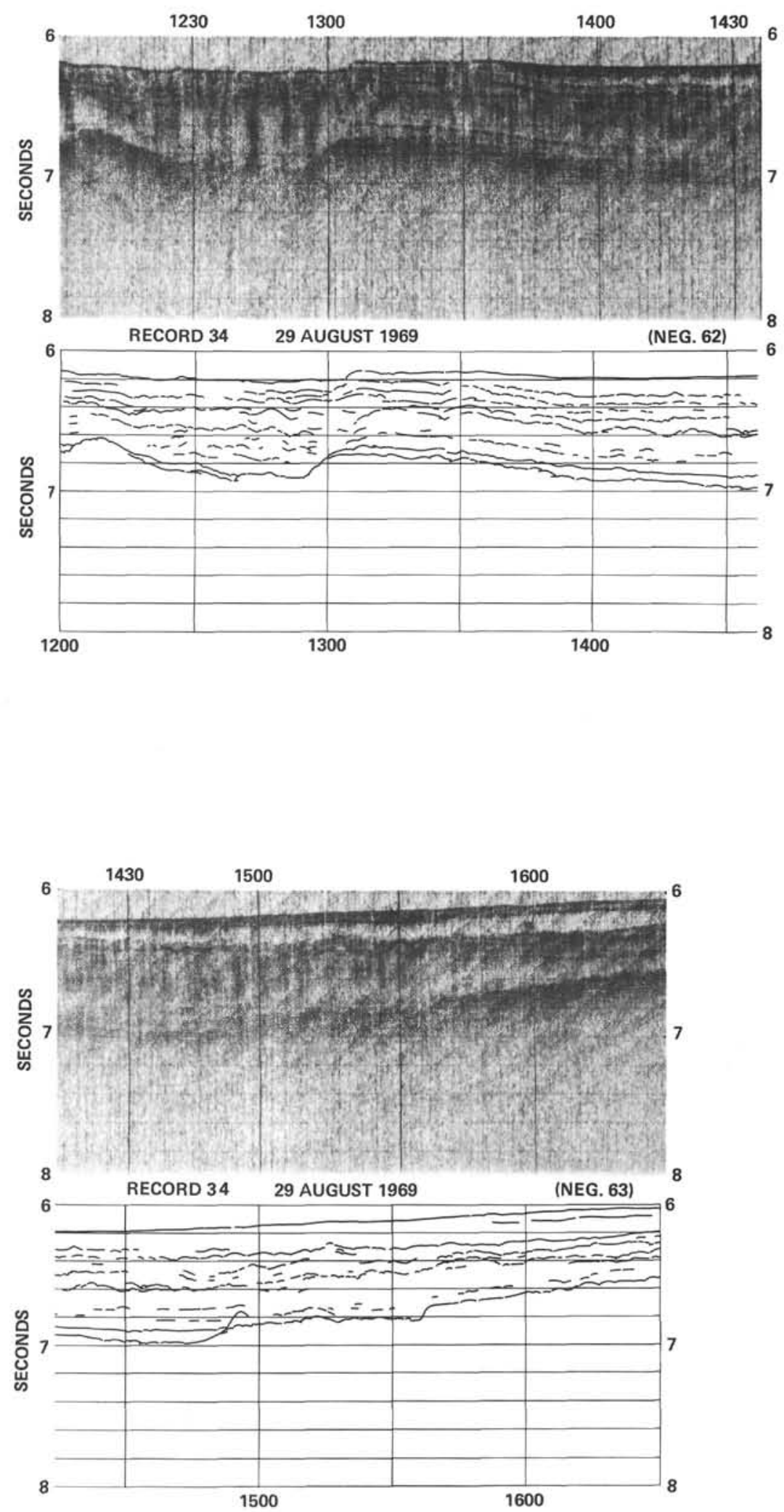

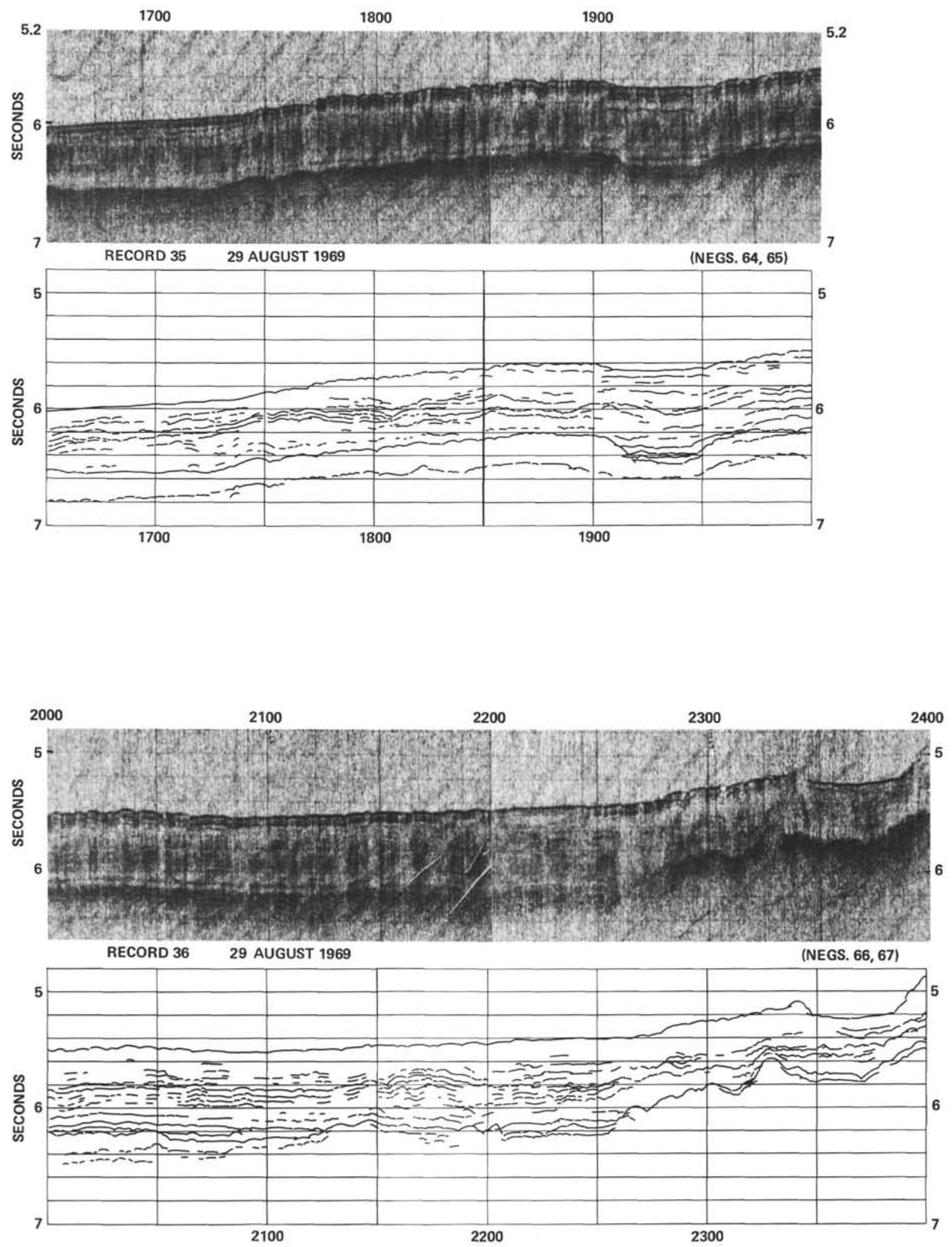

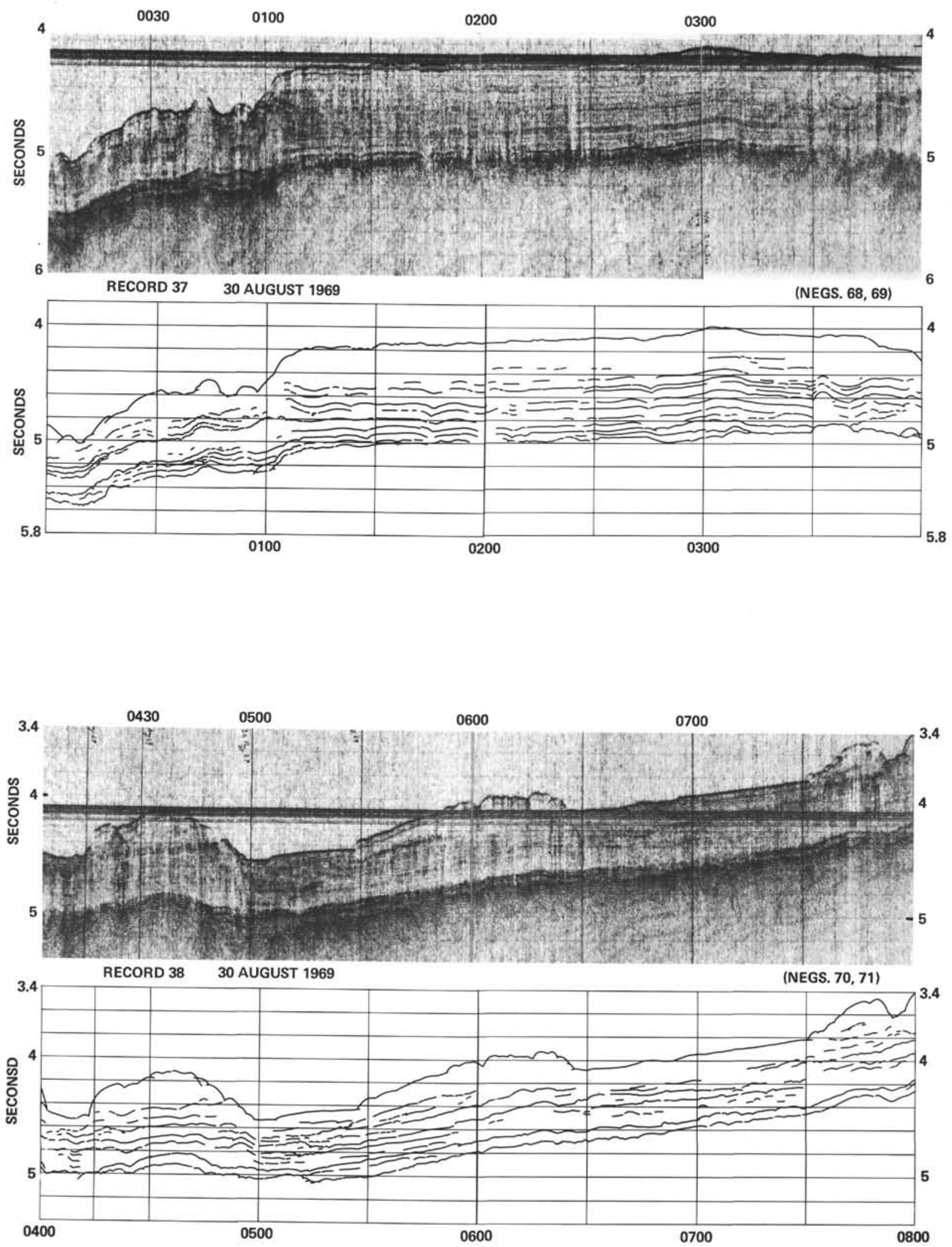

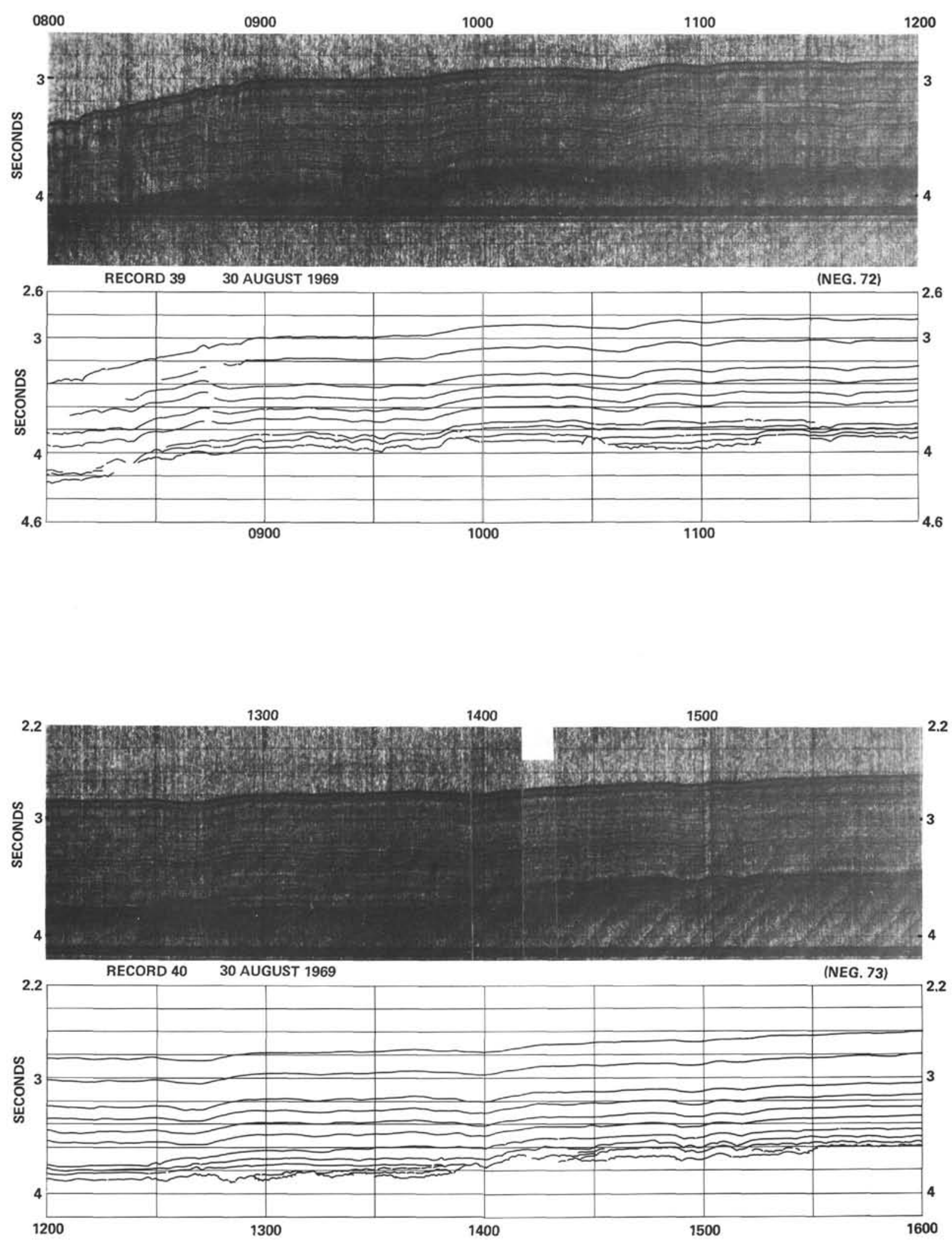

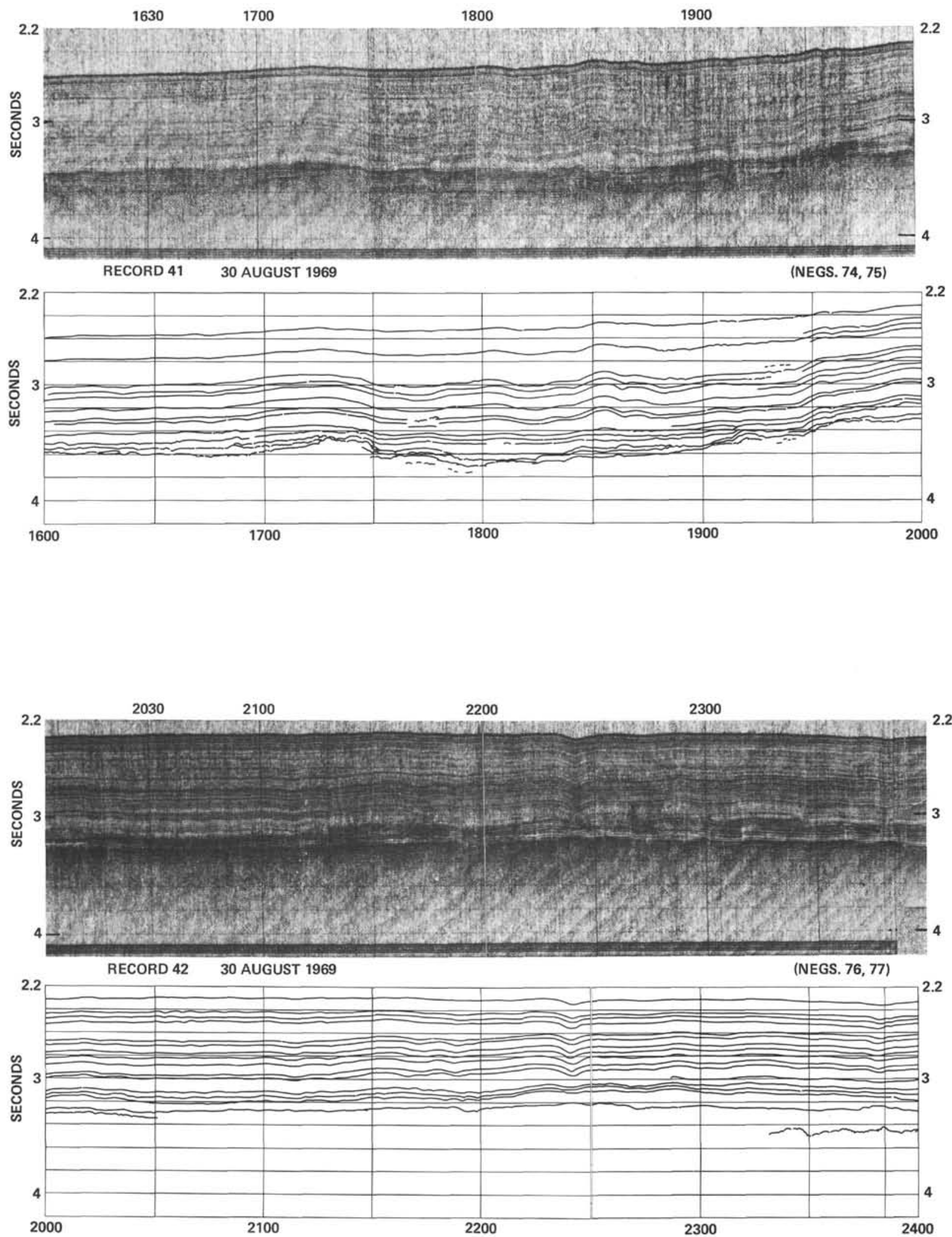

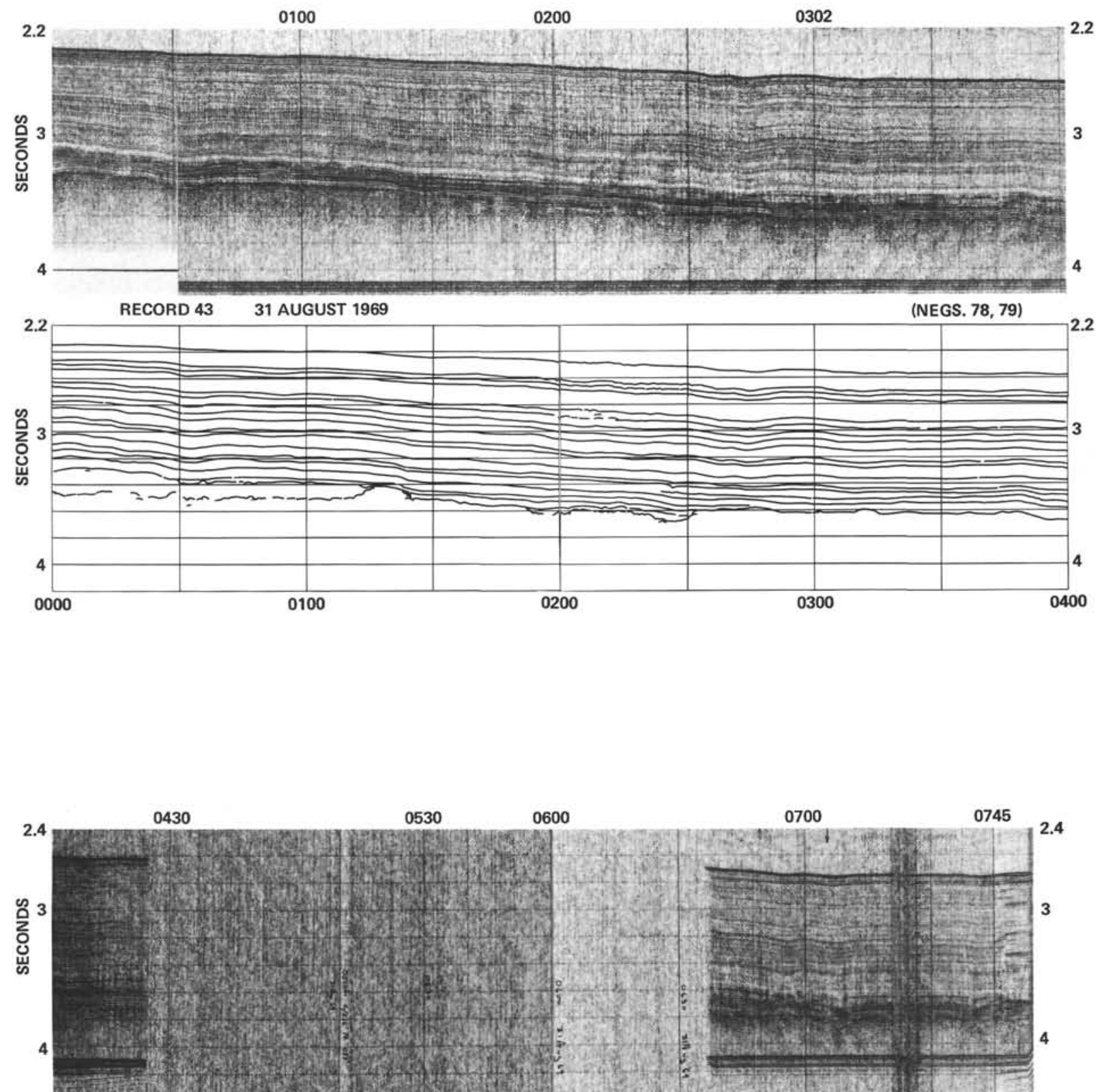

0700

0745
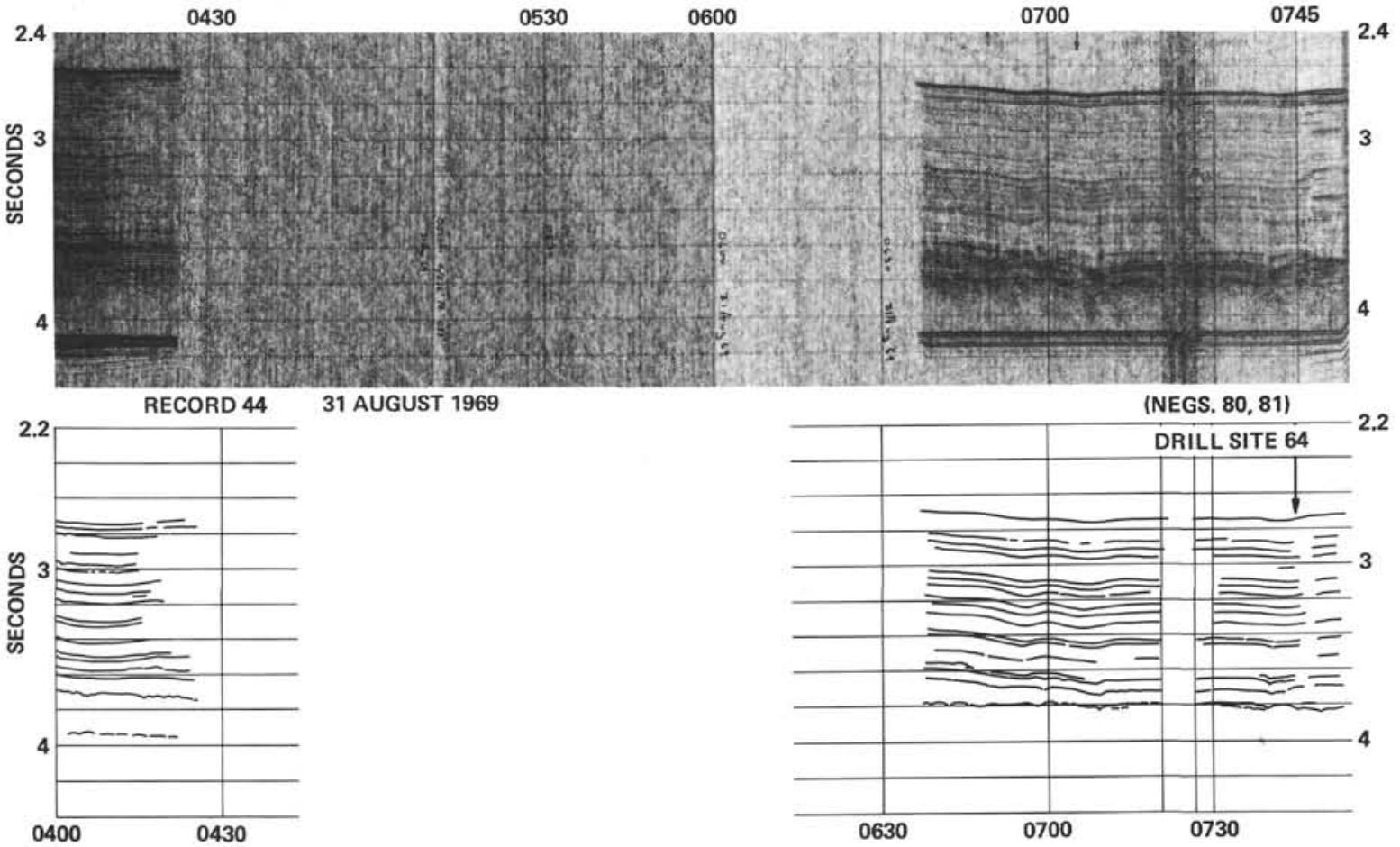

31 AUGUST 1969

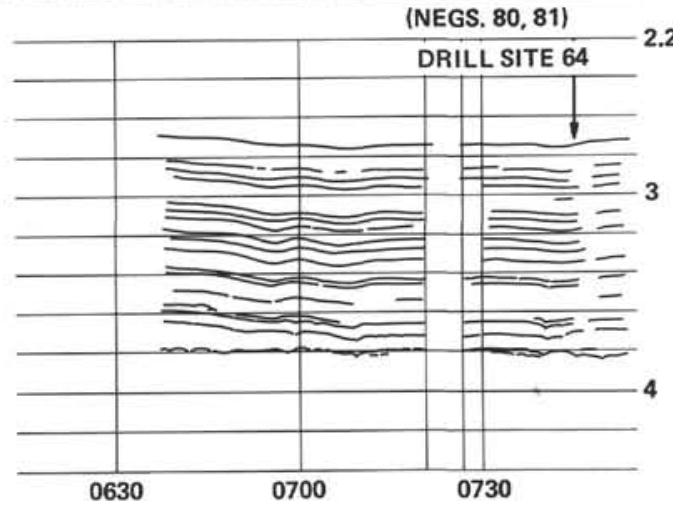



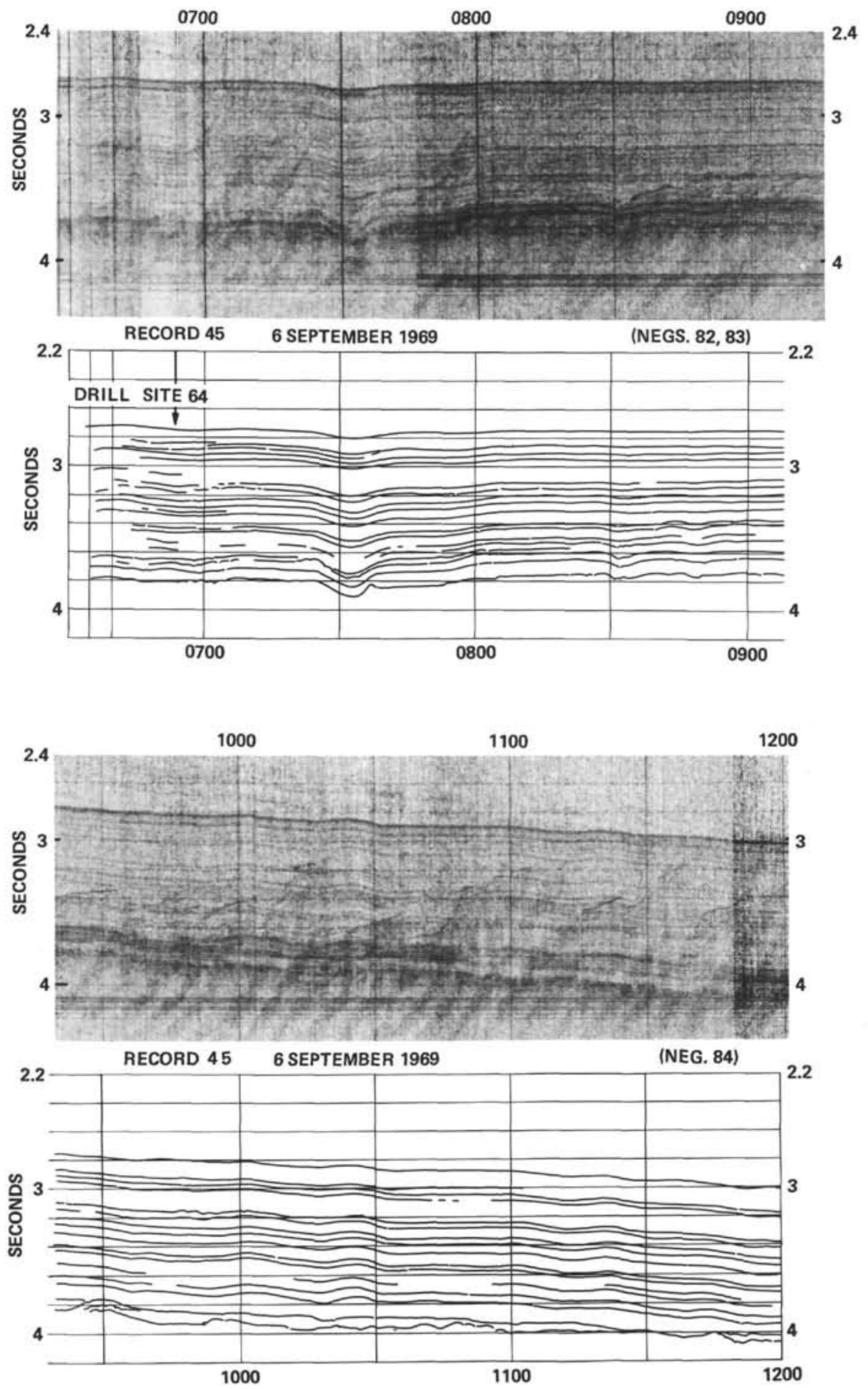

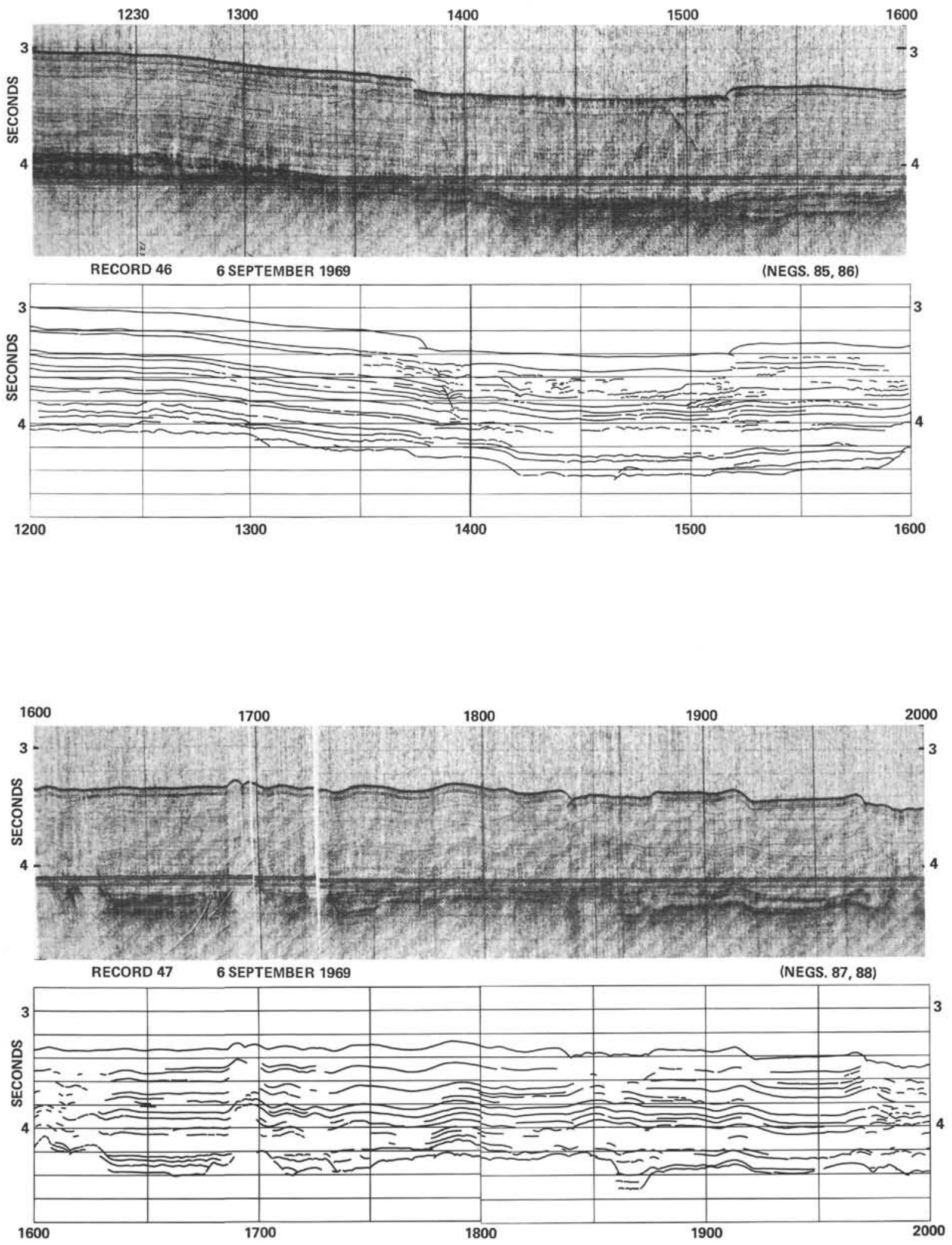

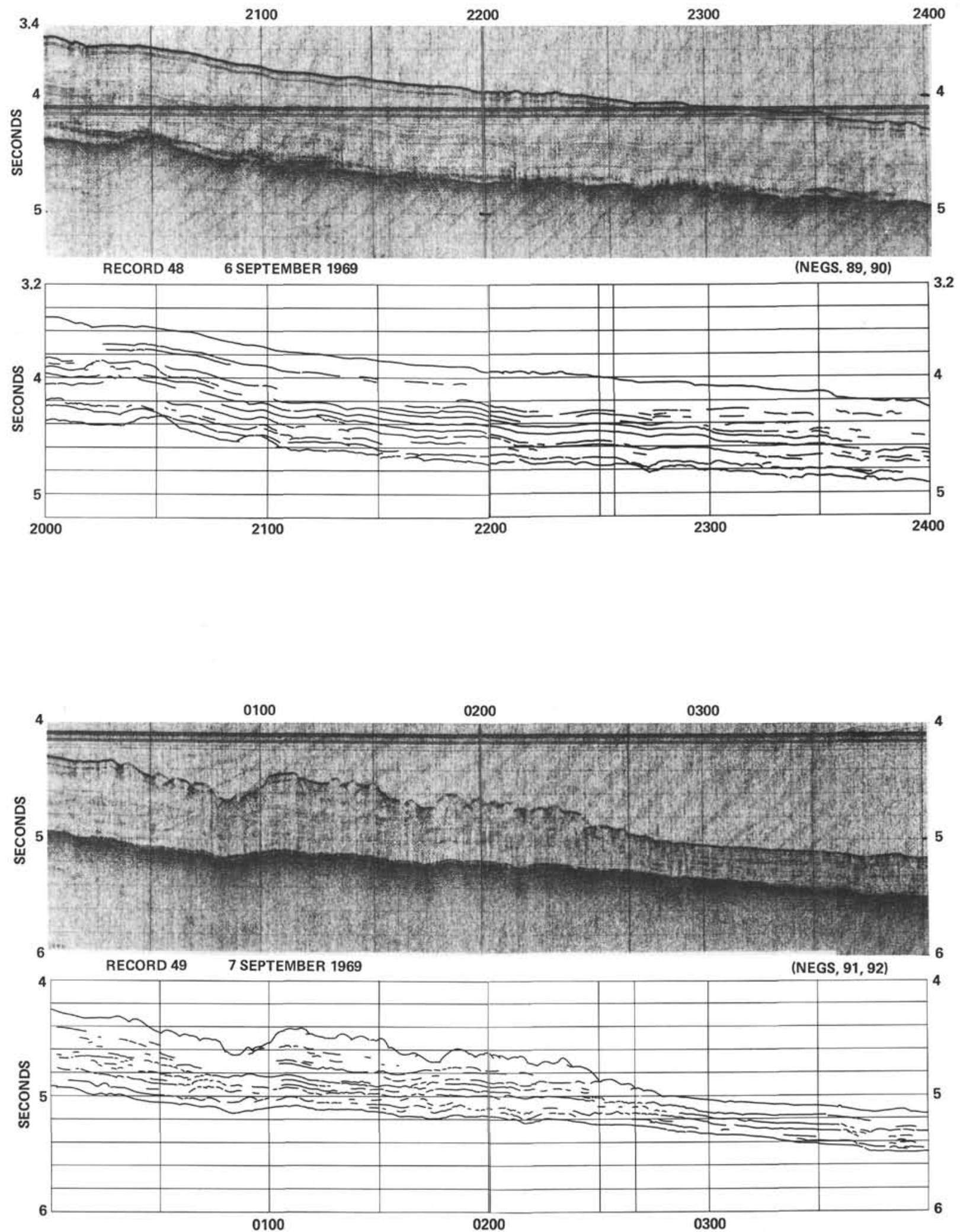

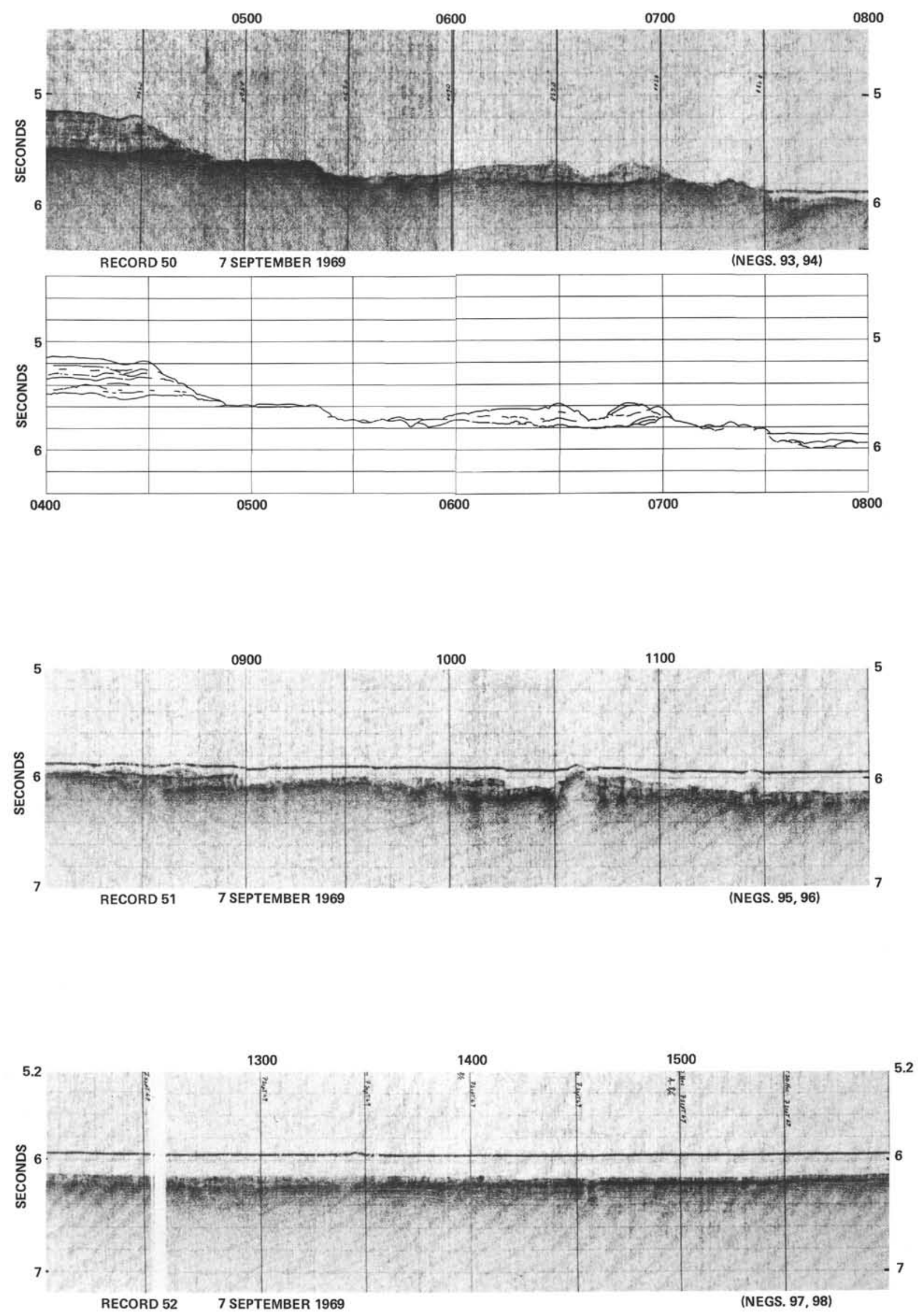

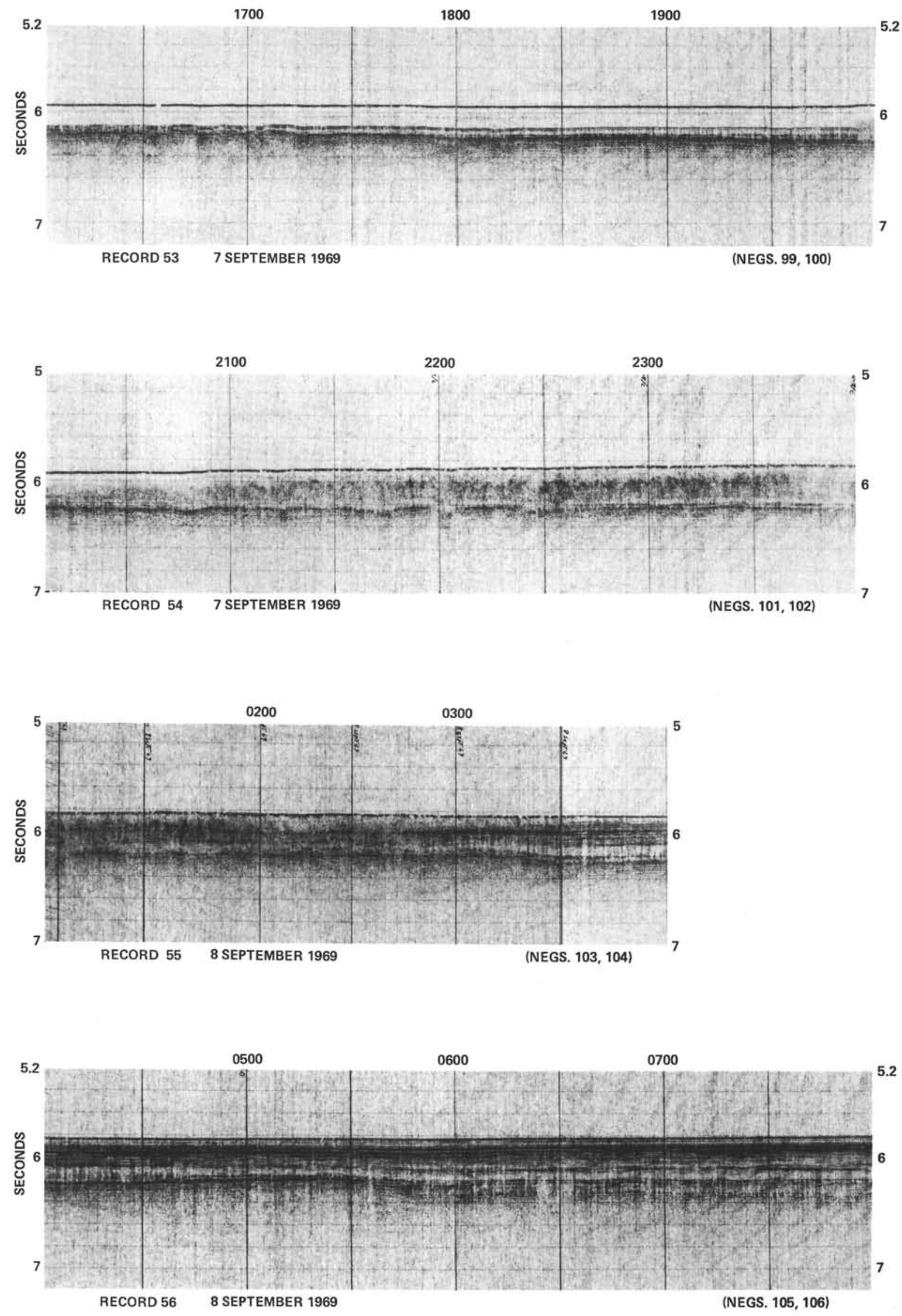

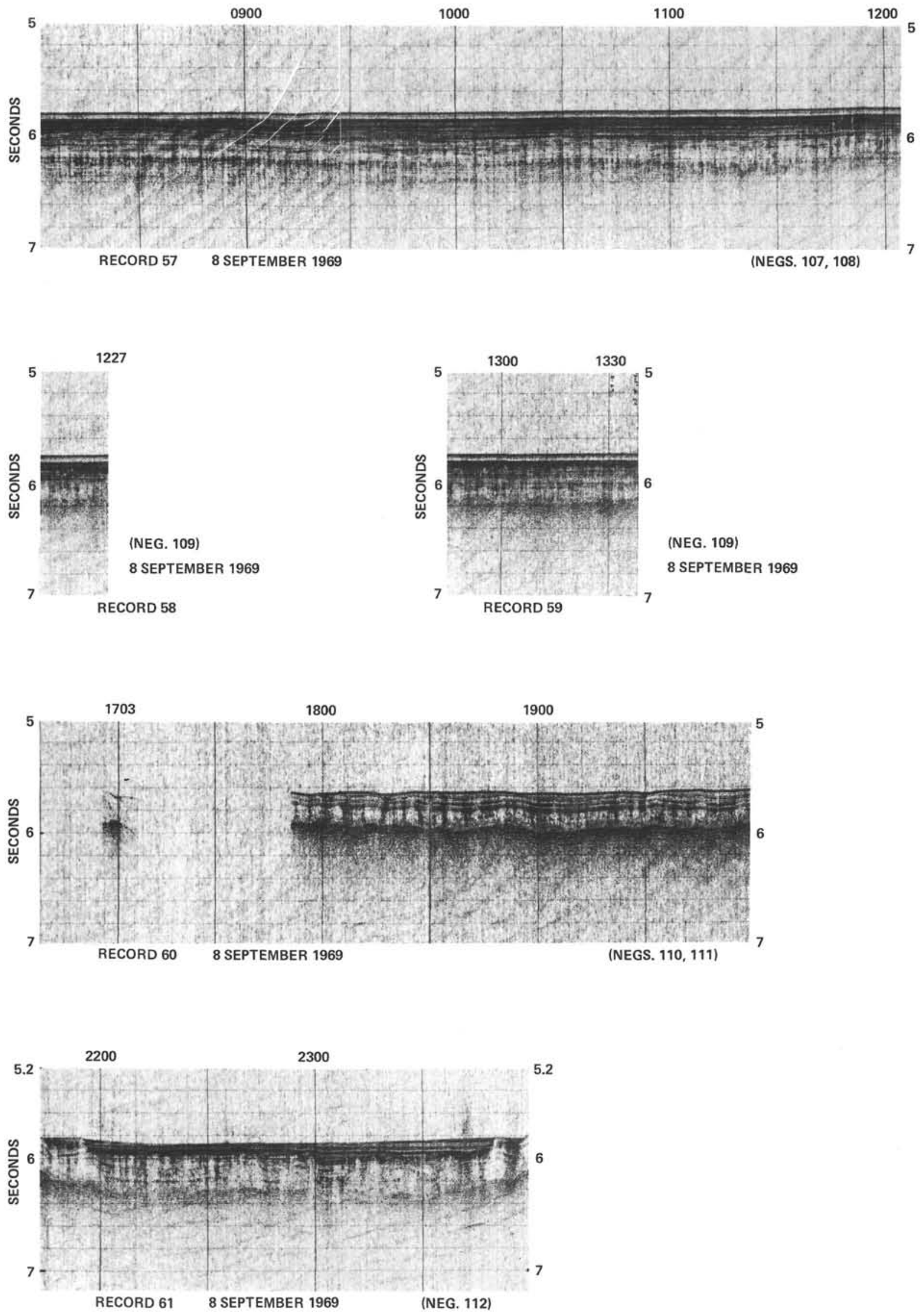

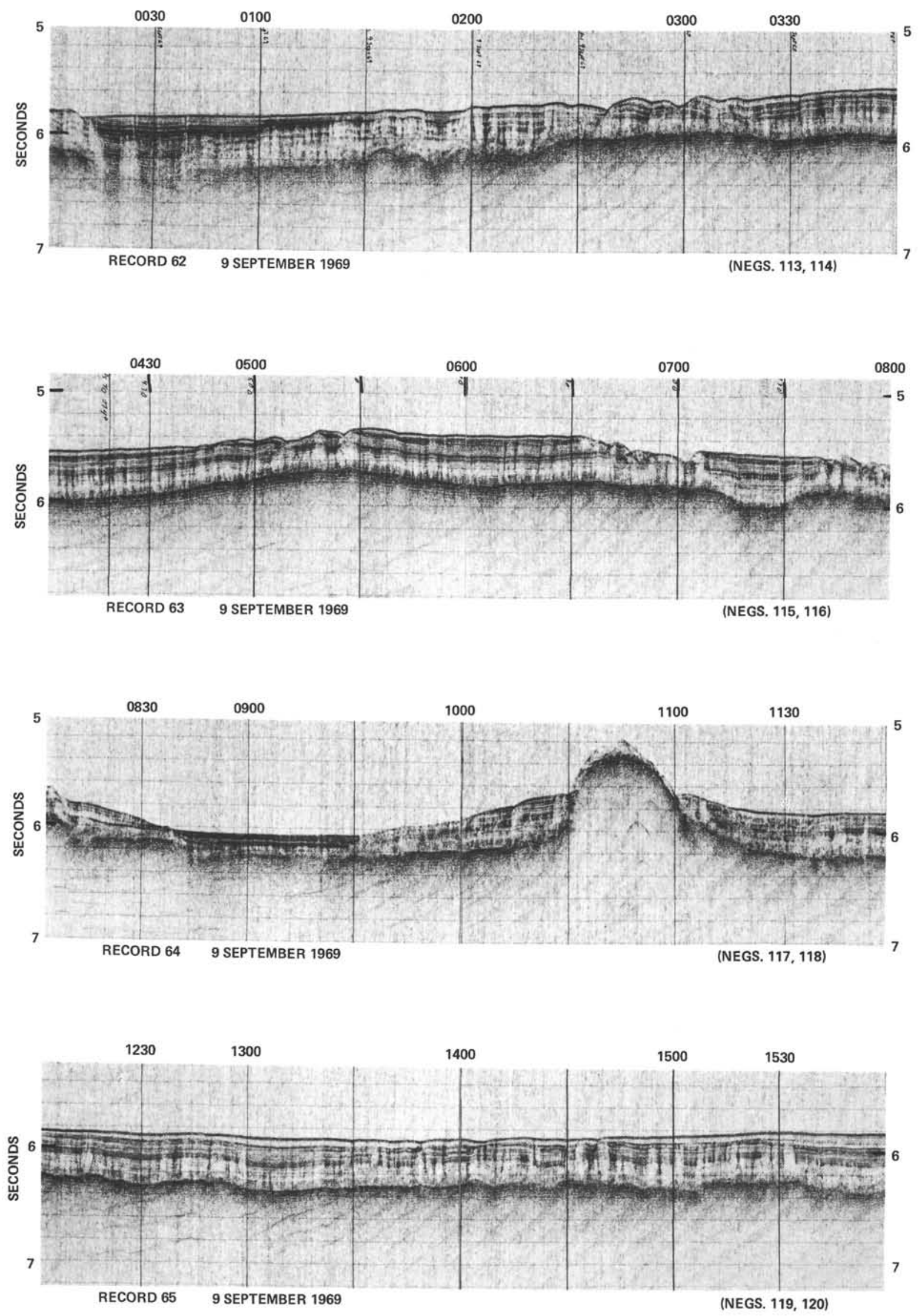

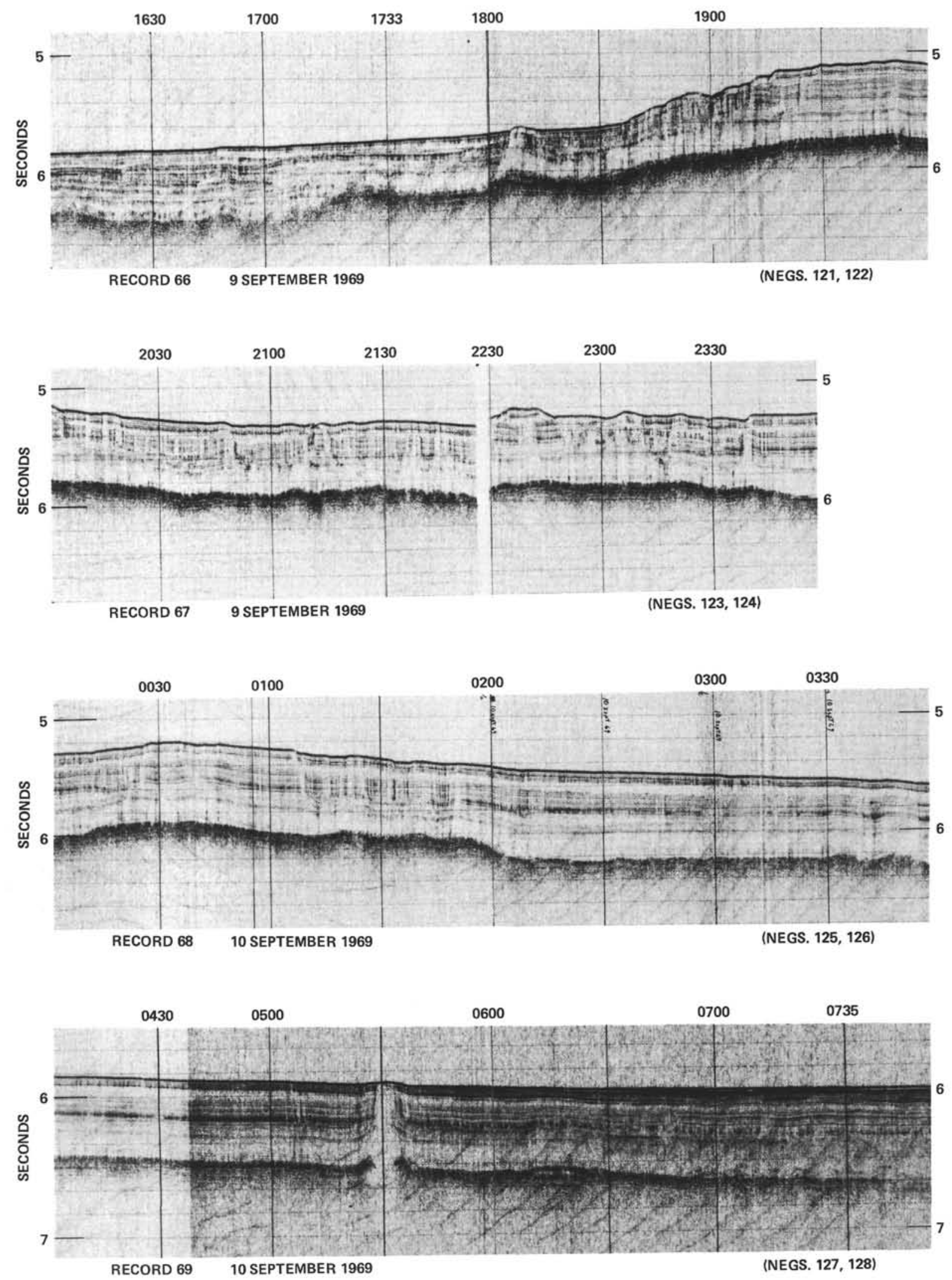

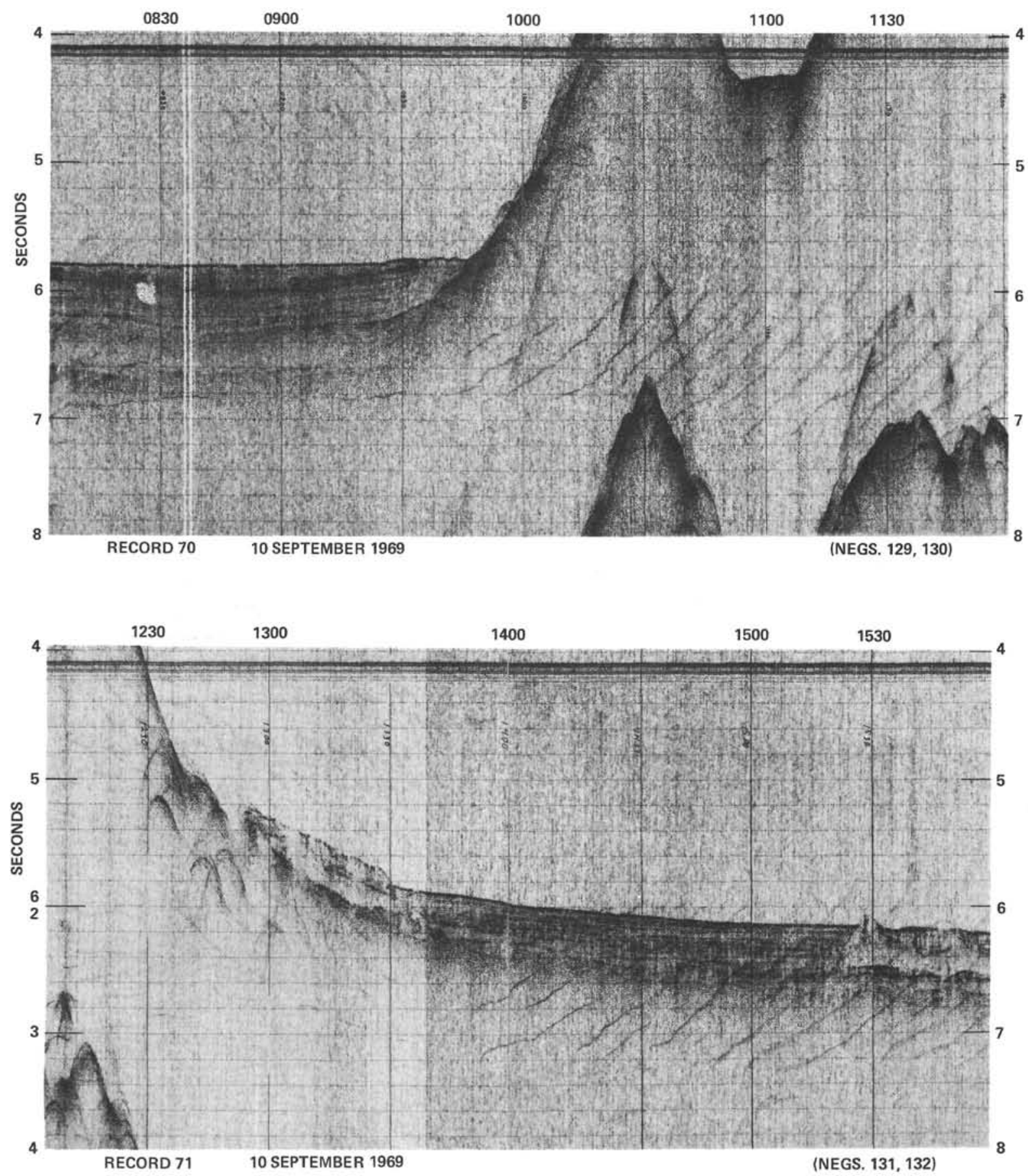

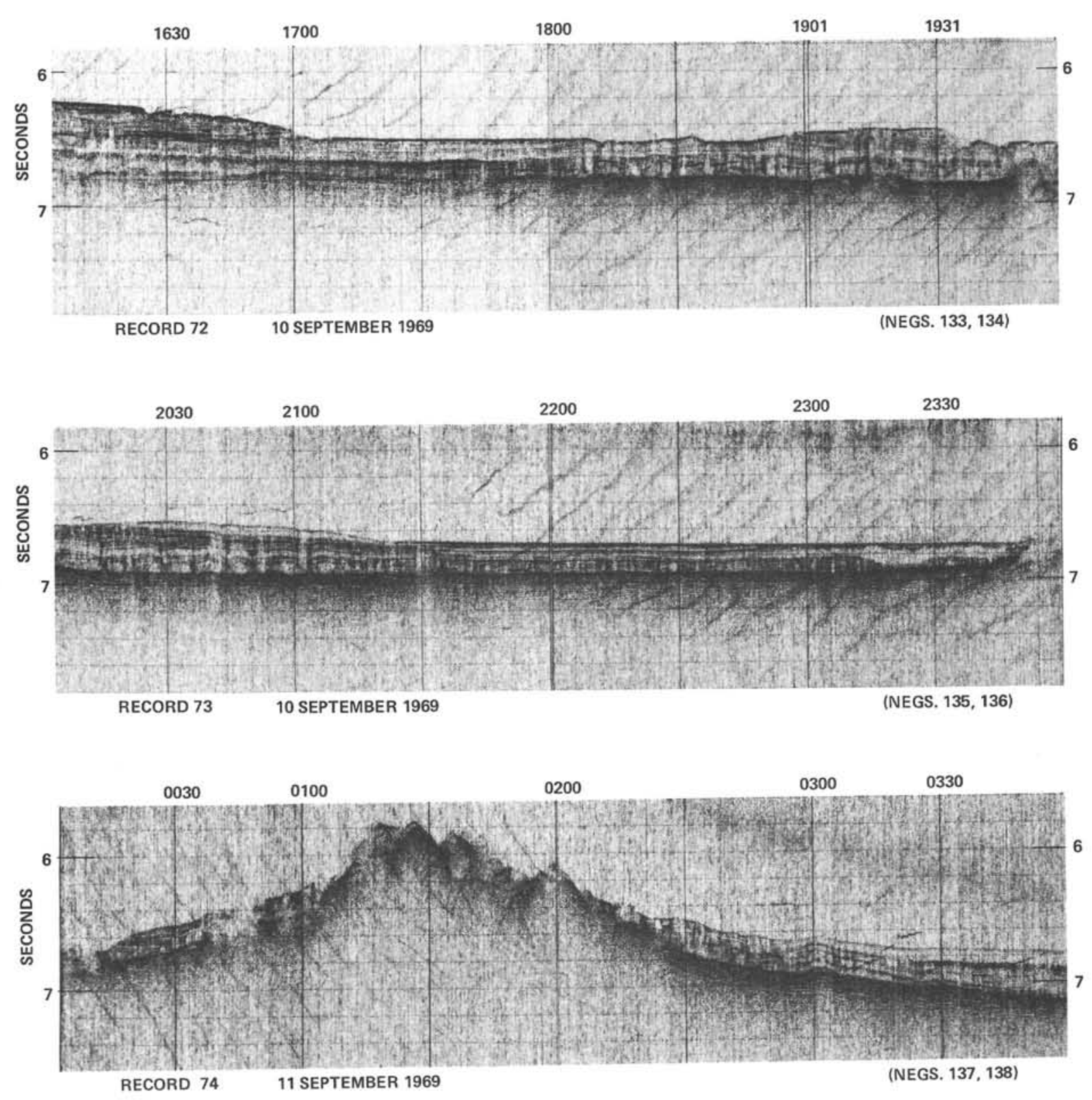

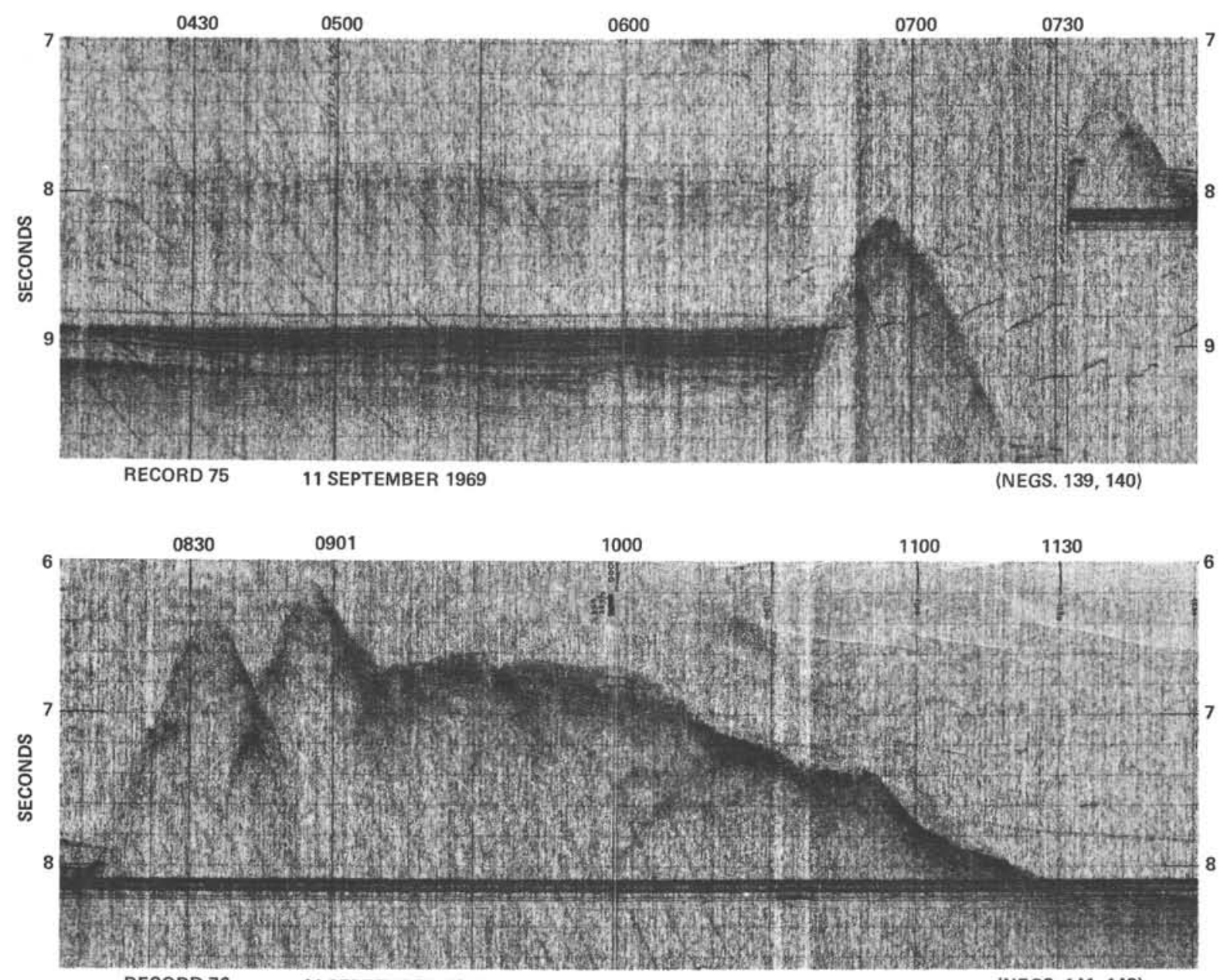

RECORD 76

11 SEPTEMBER 1969

(NEGS. 141, 142)

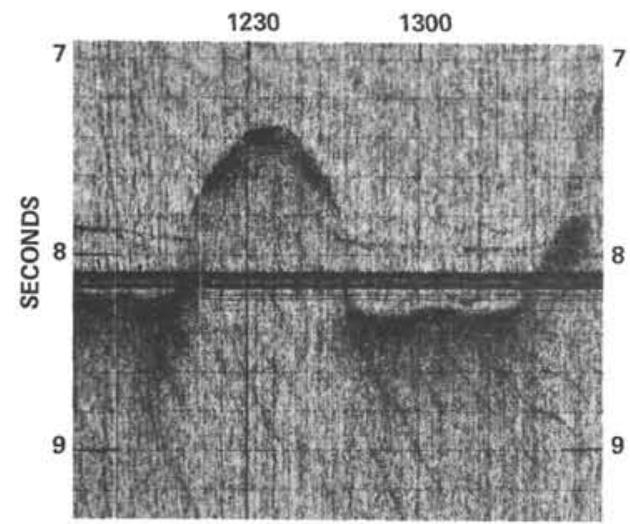

RECORD 77

11 SEPTEMBER 1969

(NEG. 143) 


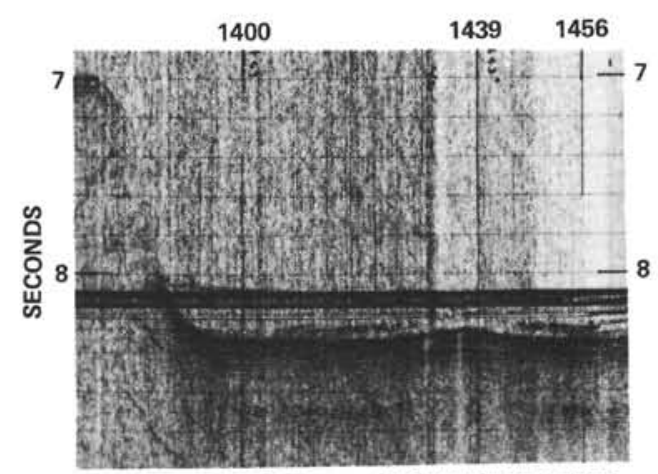

$\begin{array}{lll}\text { RECORD } 78 & 11 \text { SEPTEMBER } 1969 & \text { (NEG. 144) }\end{array}$
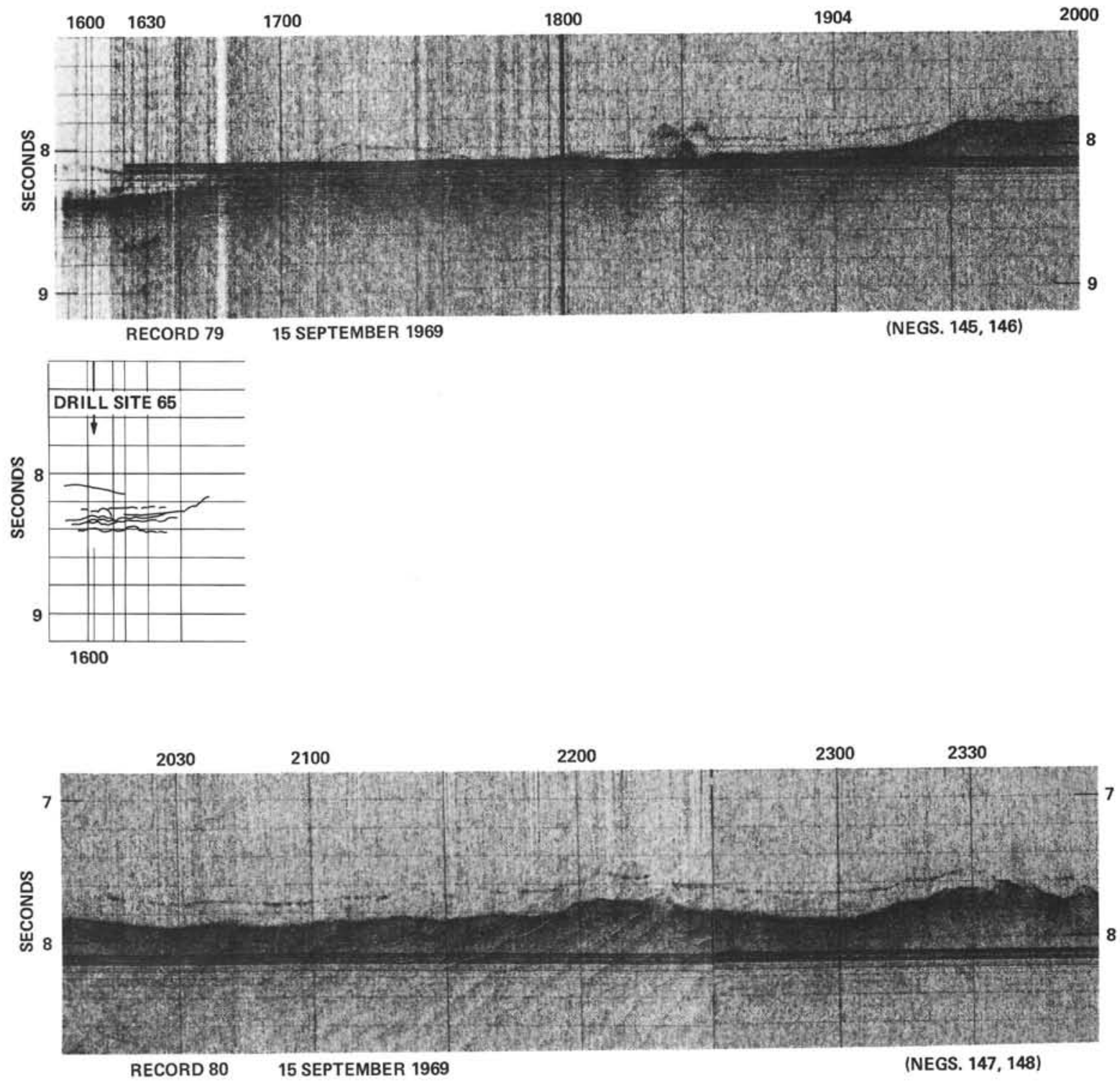

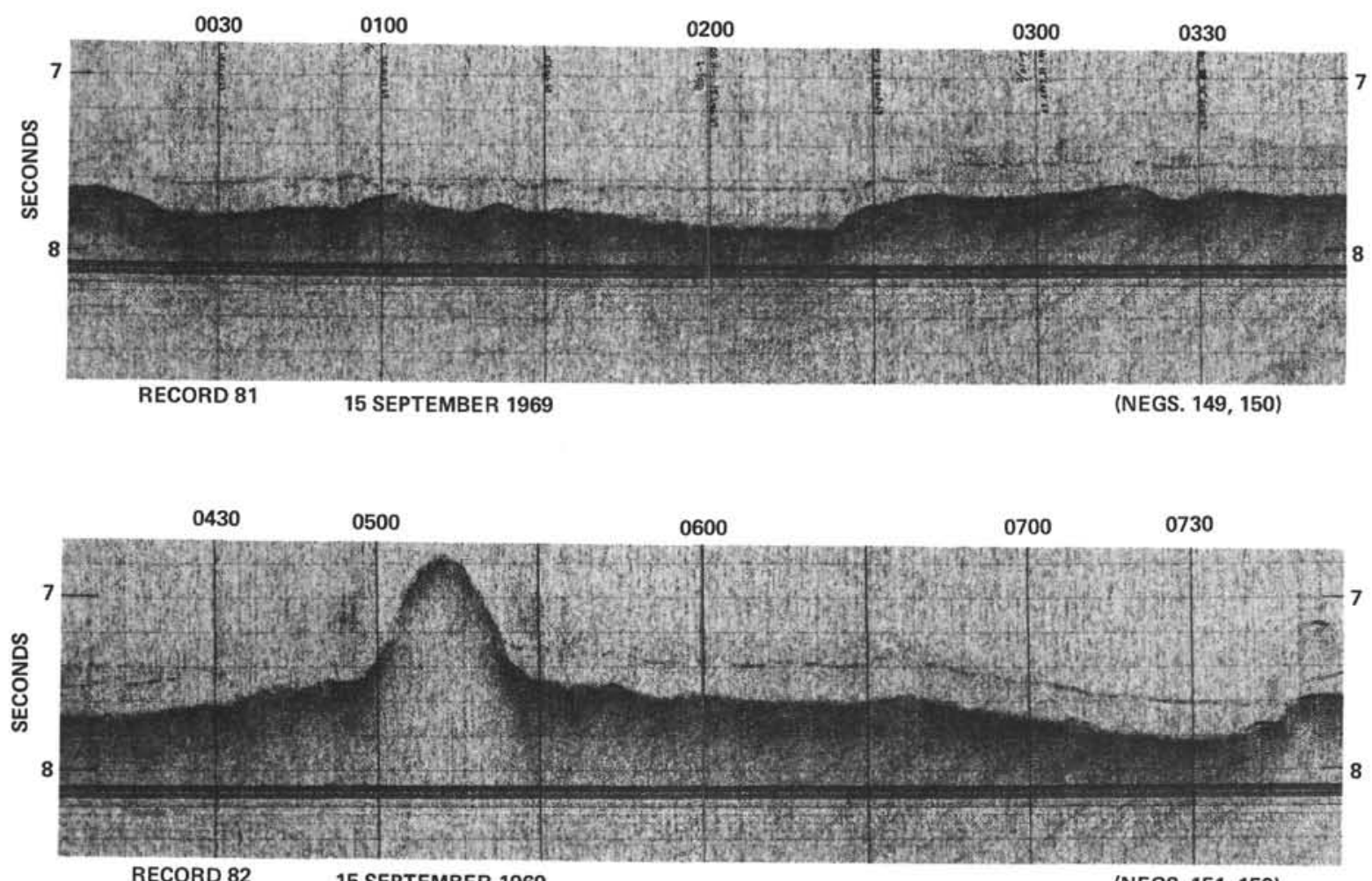

RECORD 82

15 SEPTEMBER 1969

(NEGS. 151, 152)
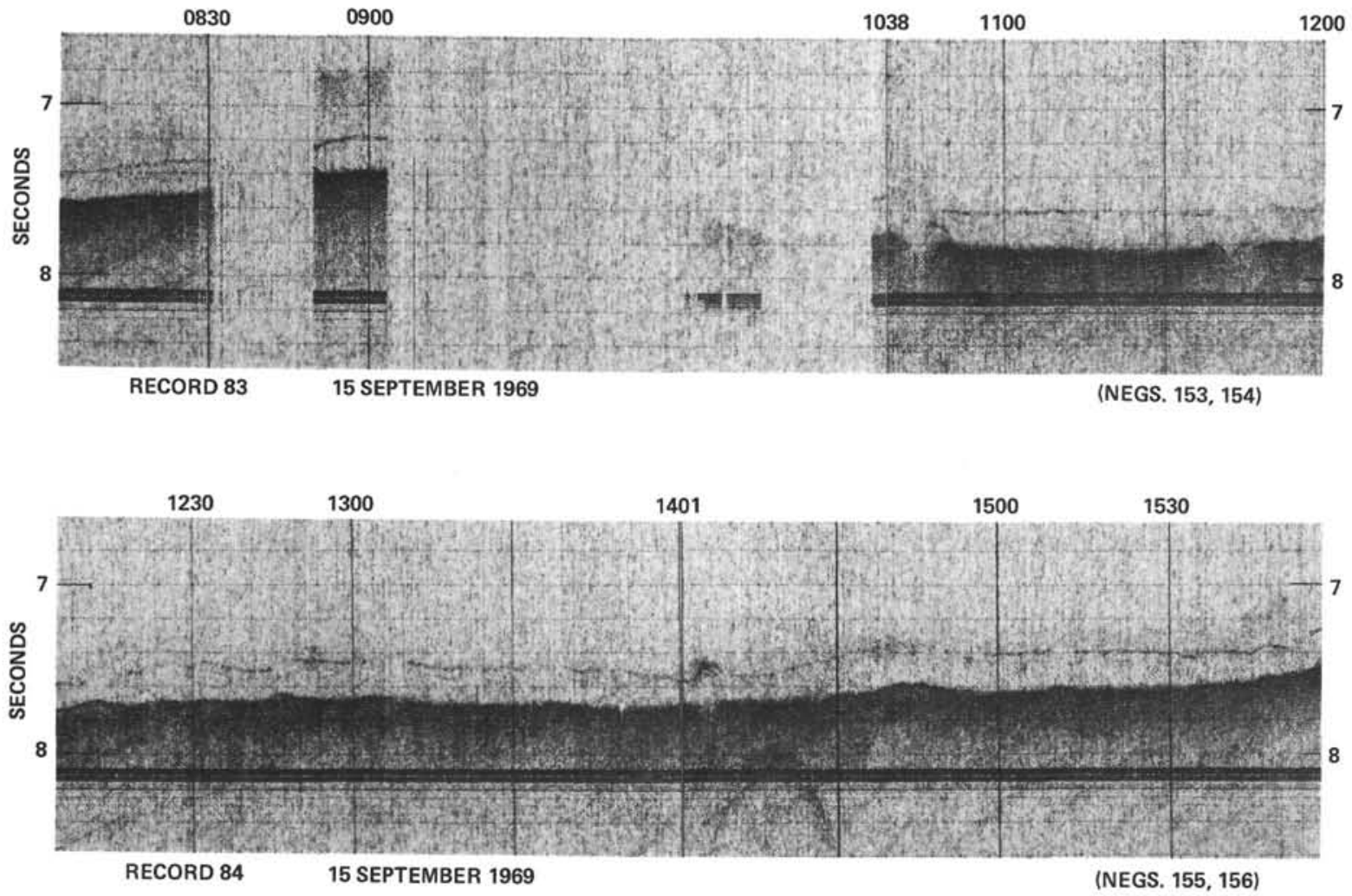

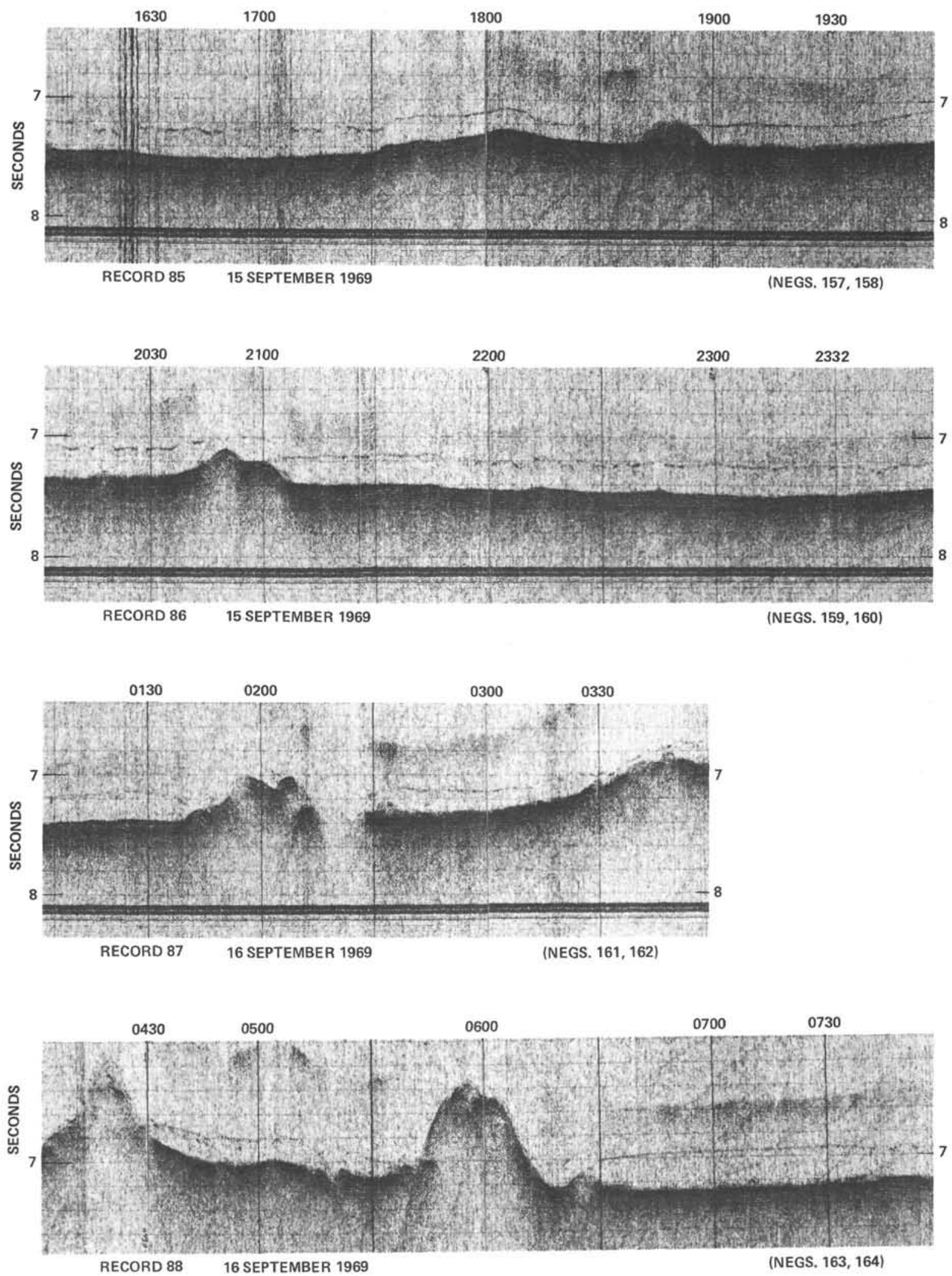


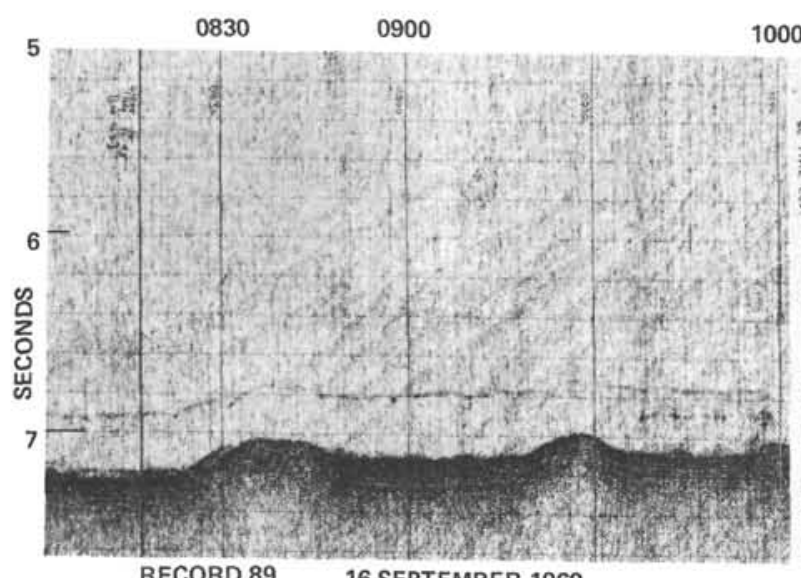

RECORD $89 \quad 16$ SEPTEMBER 1969
$1000 \quad 1100$

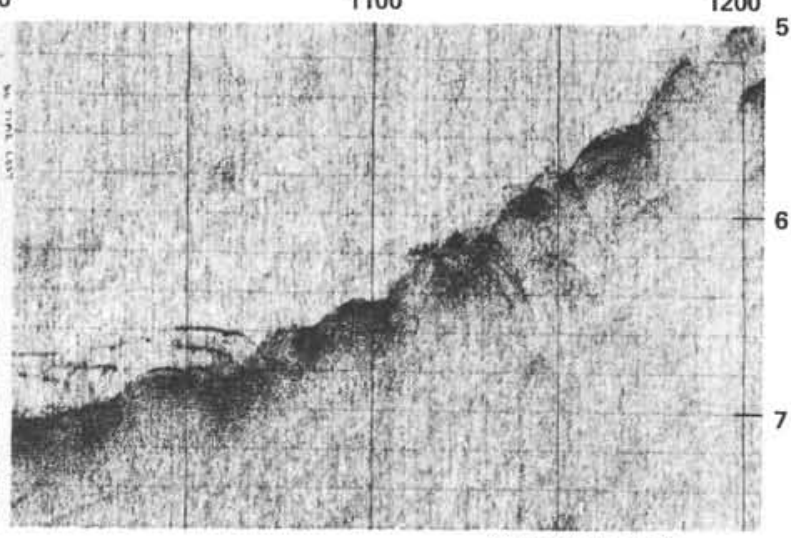

(NEGS. 165, 166)
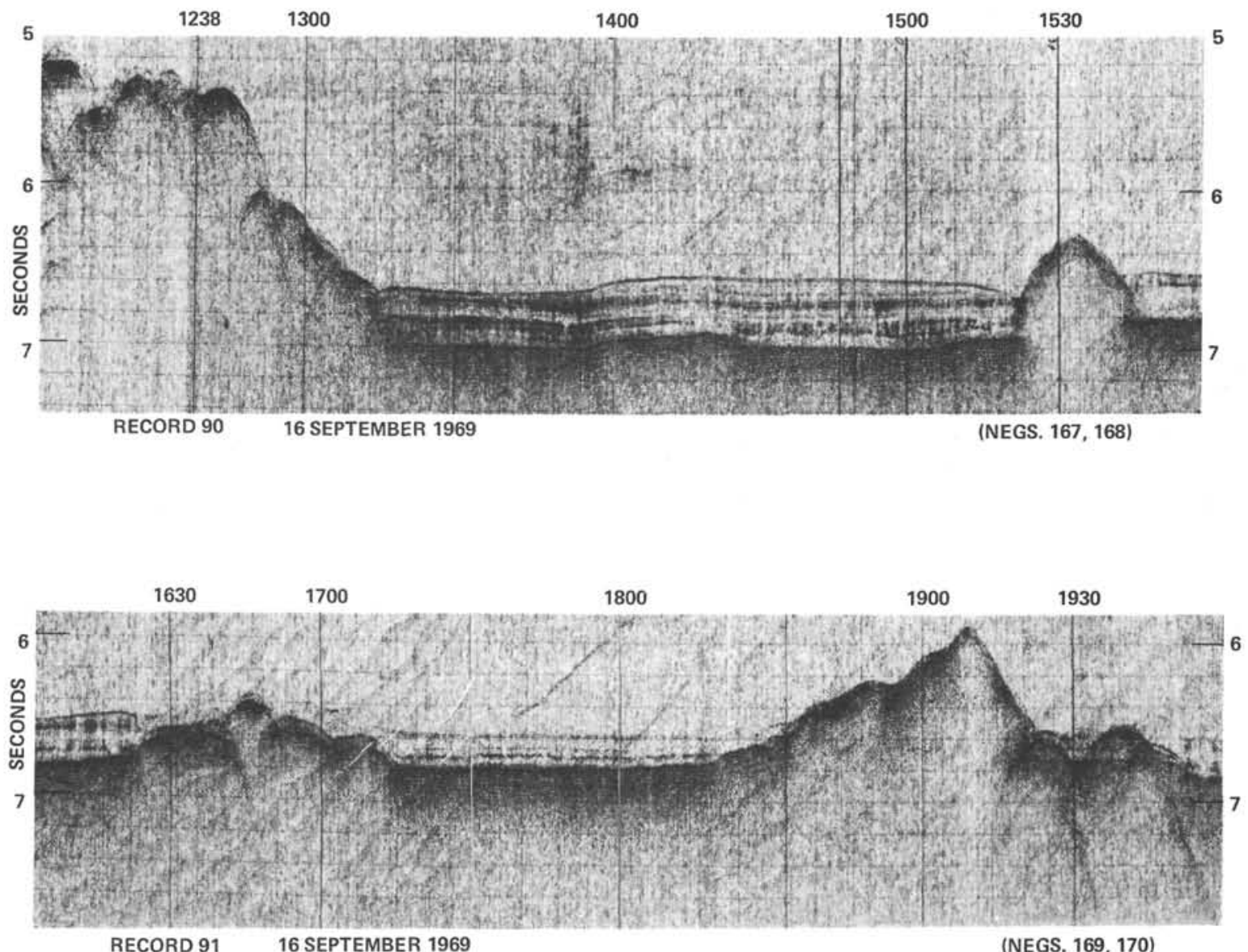


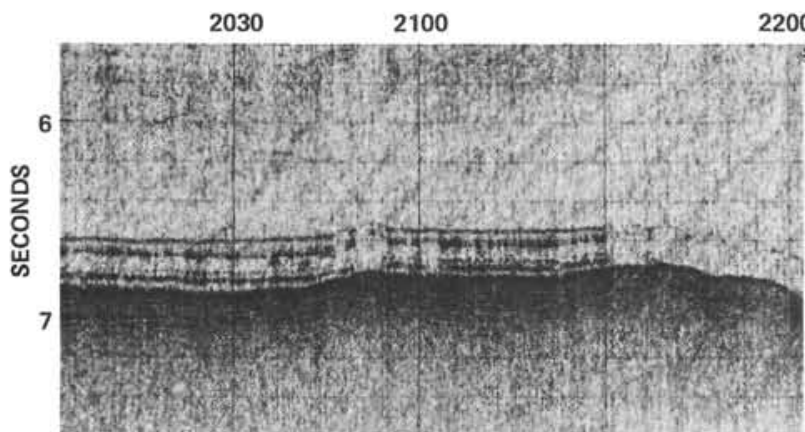

RECORD 92
16 SEPTEMBER 1969
$2300 \quad 2330$

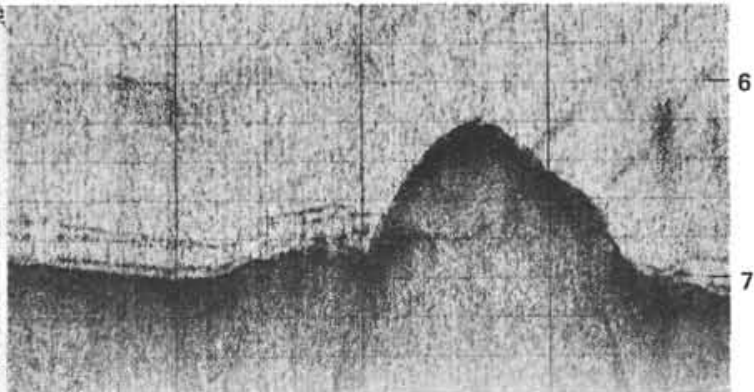

(NEGS. 171, 172)

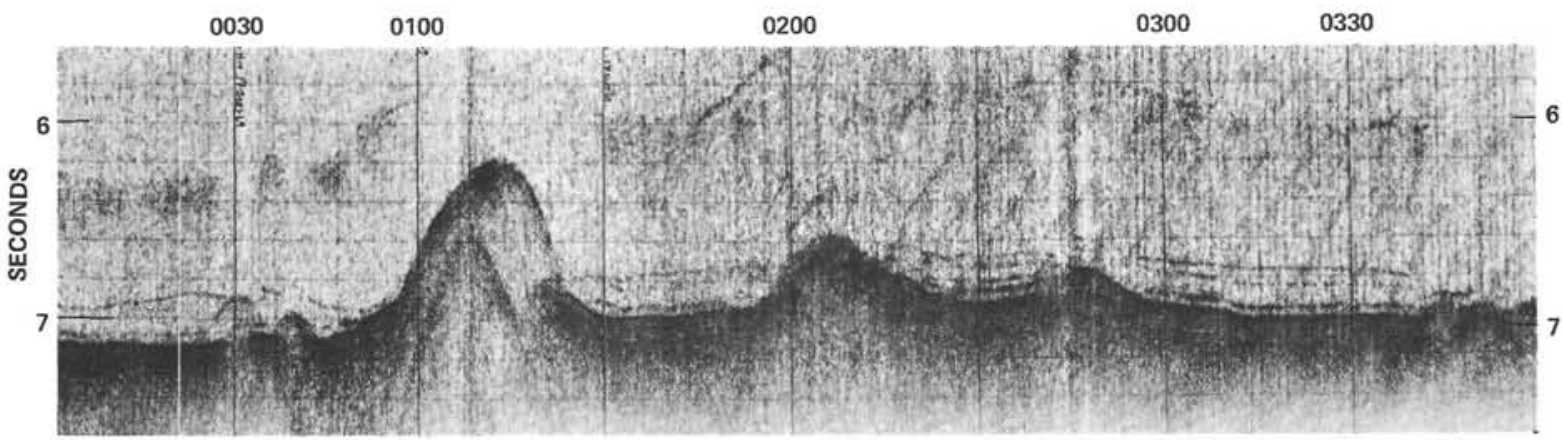

RECORD 93

17 SEPTEMBER 1969

(NEGS. 173, 174)

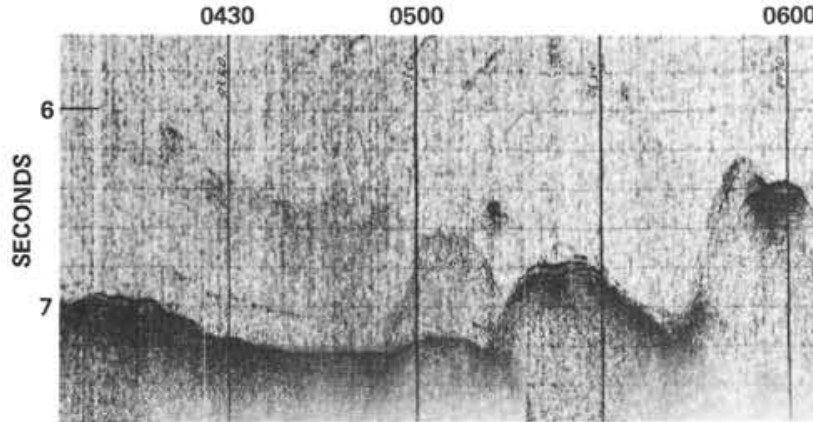

RECORD 94

17 SEPTEMBER 1969

0700

0730

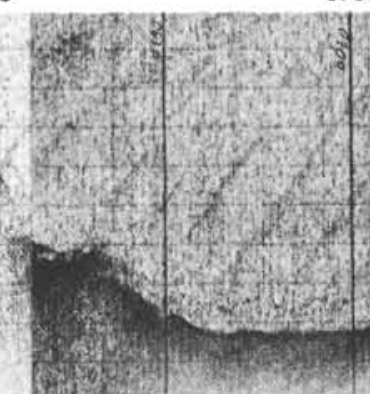

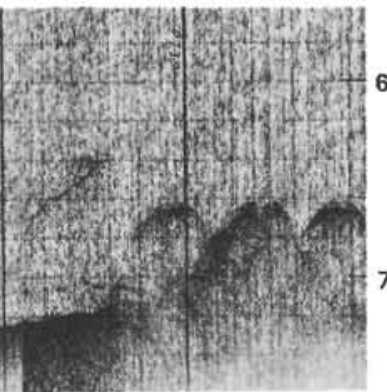

(NEGS. 175, 176)

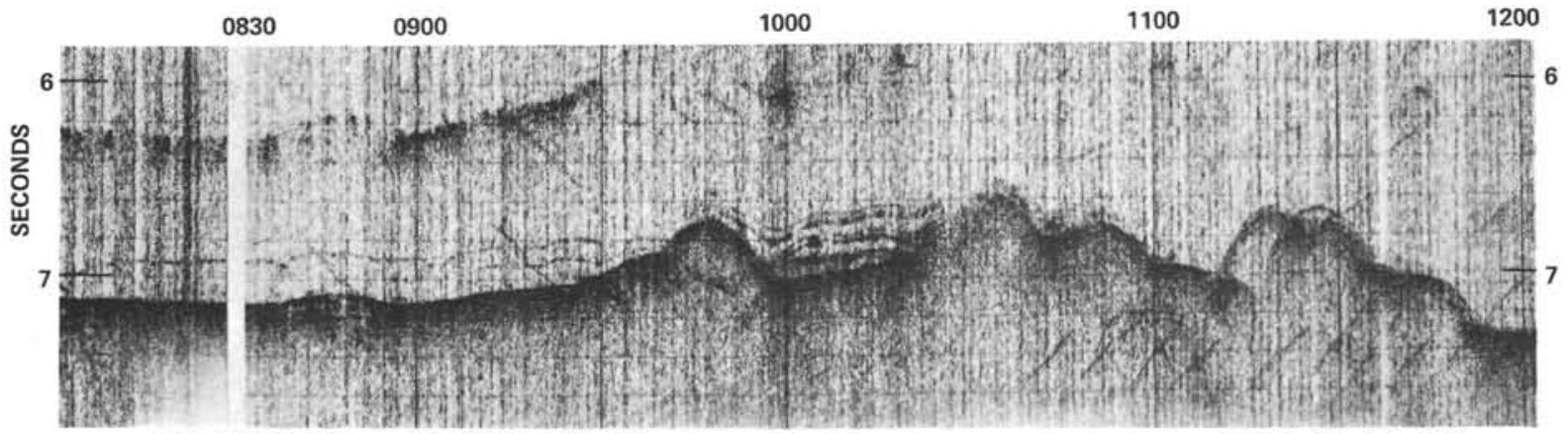

RECORDS 95,96

17 SEPTEMBER 1969

(NEGS. 177, 178, 179) 

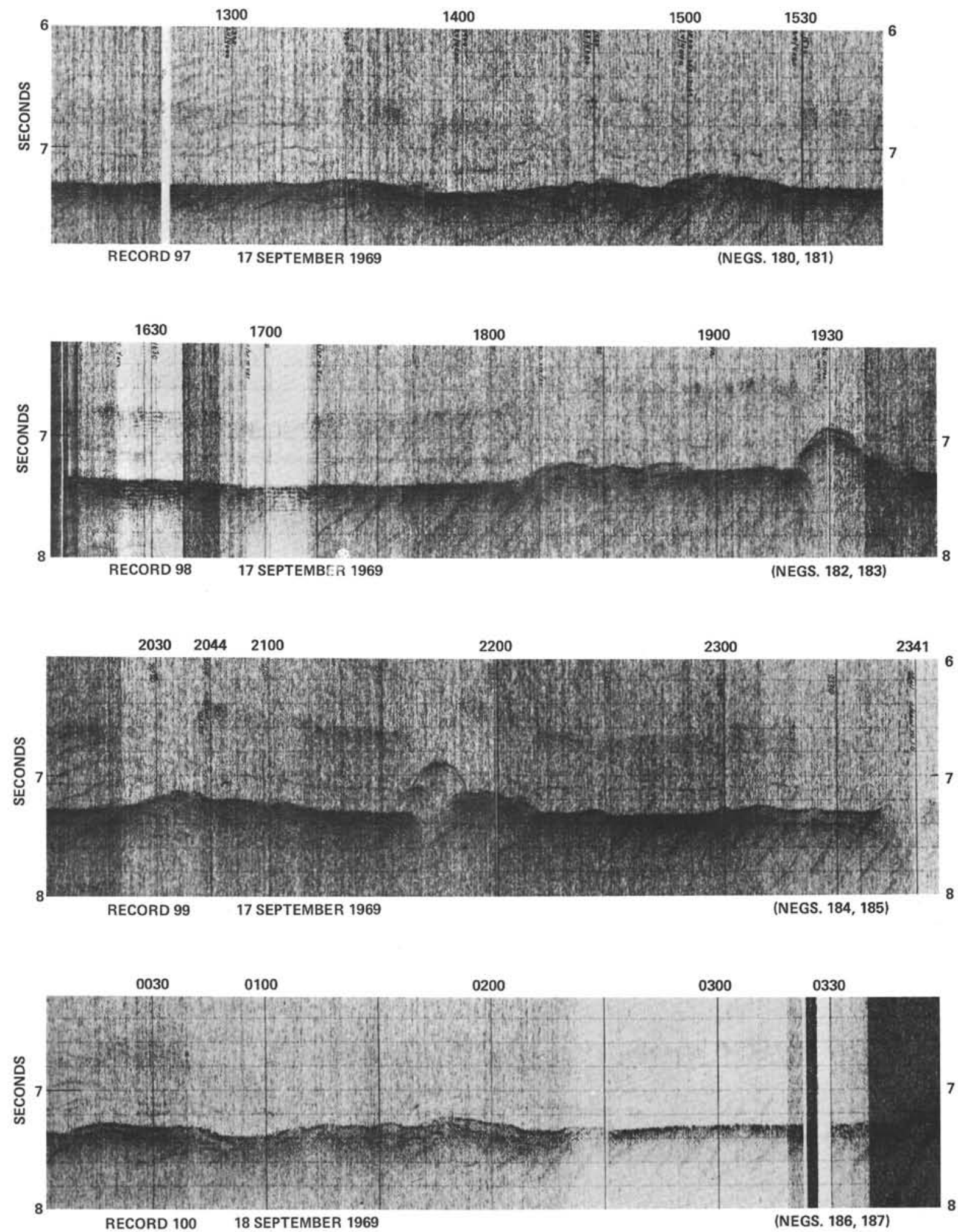

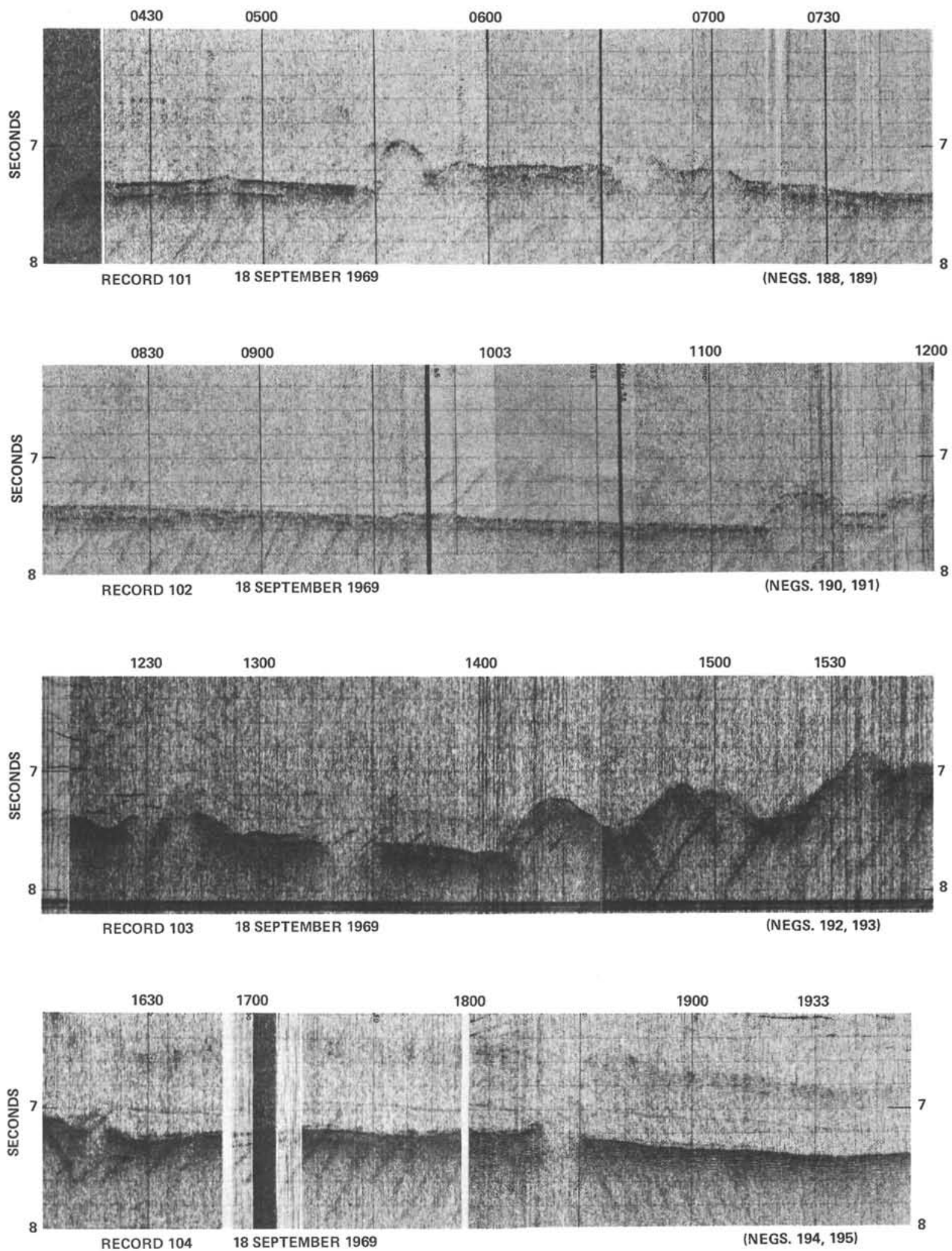

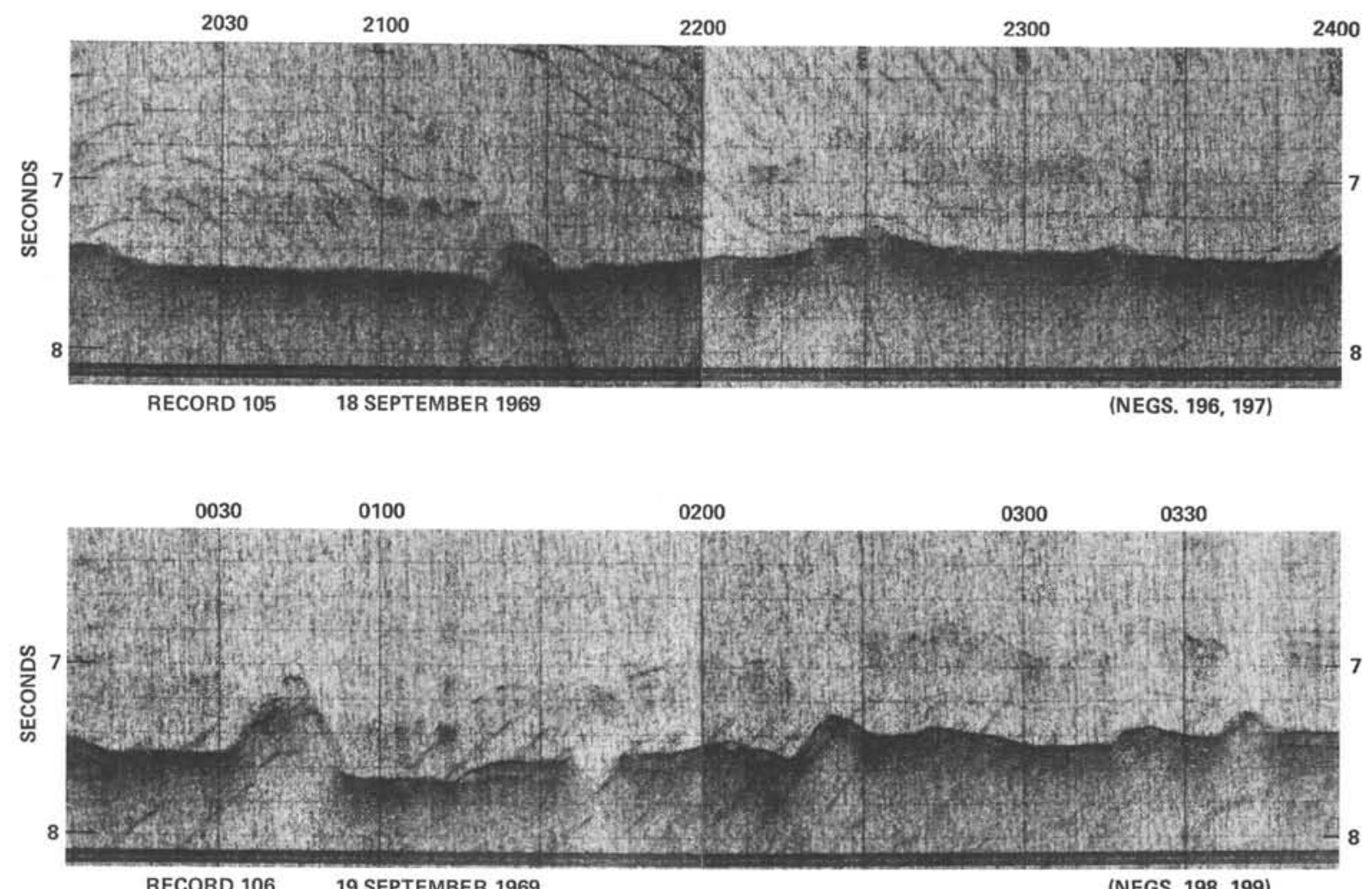

RECORD 106

19 SEPTEMBER 1969

(NEGS. 198, 199)
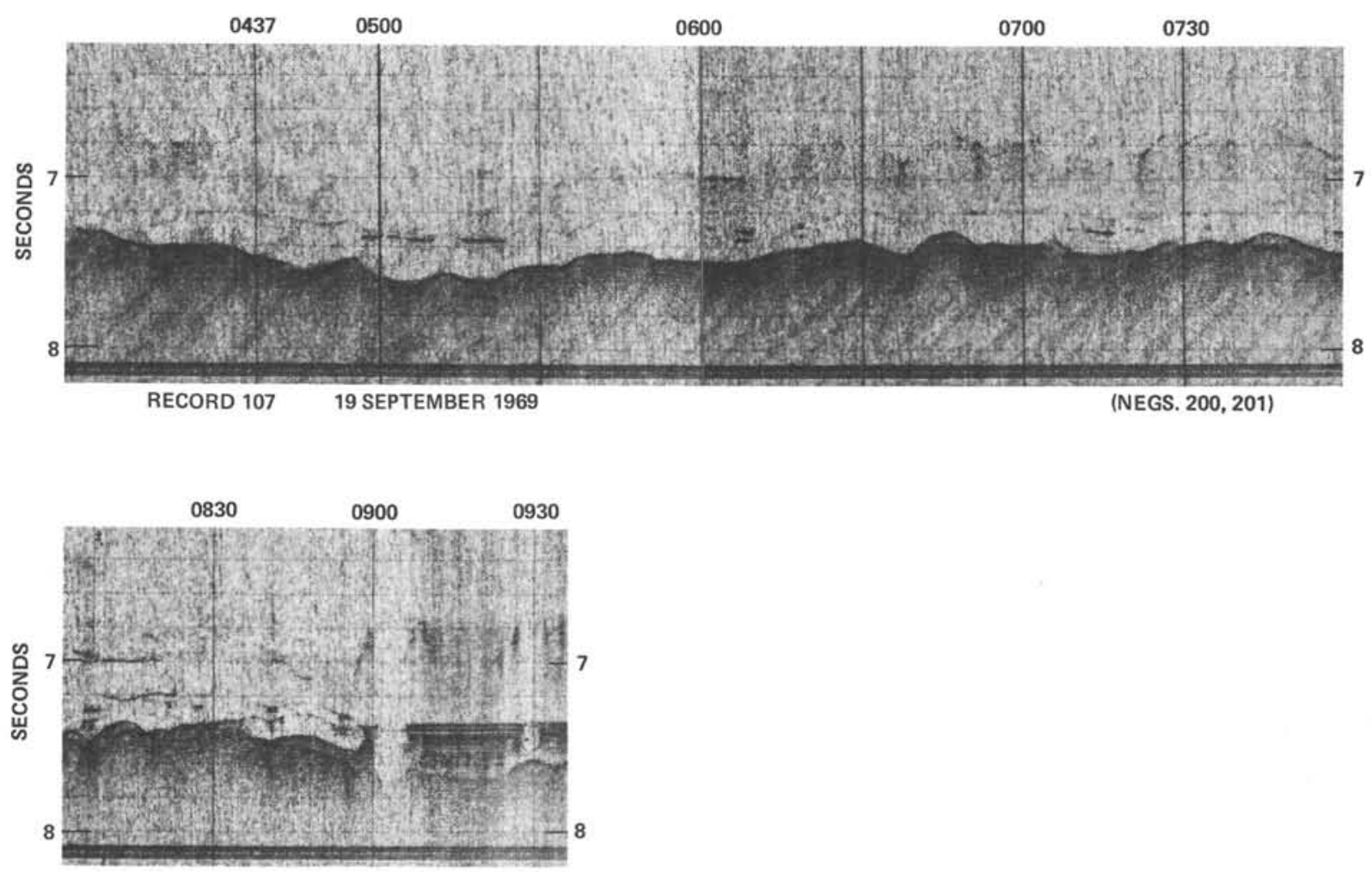

RECORD 108

19 SEPTEMBER 1969 (NEG. 202) 

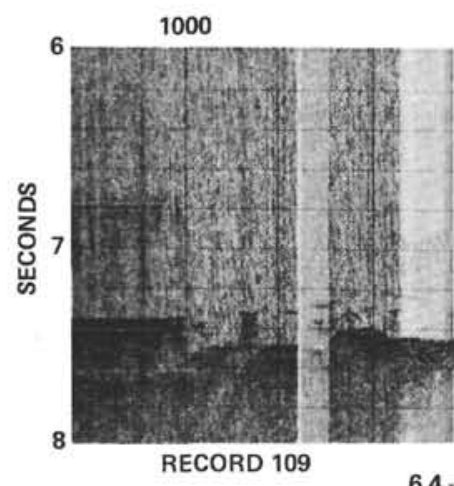

1100

1200

1235
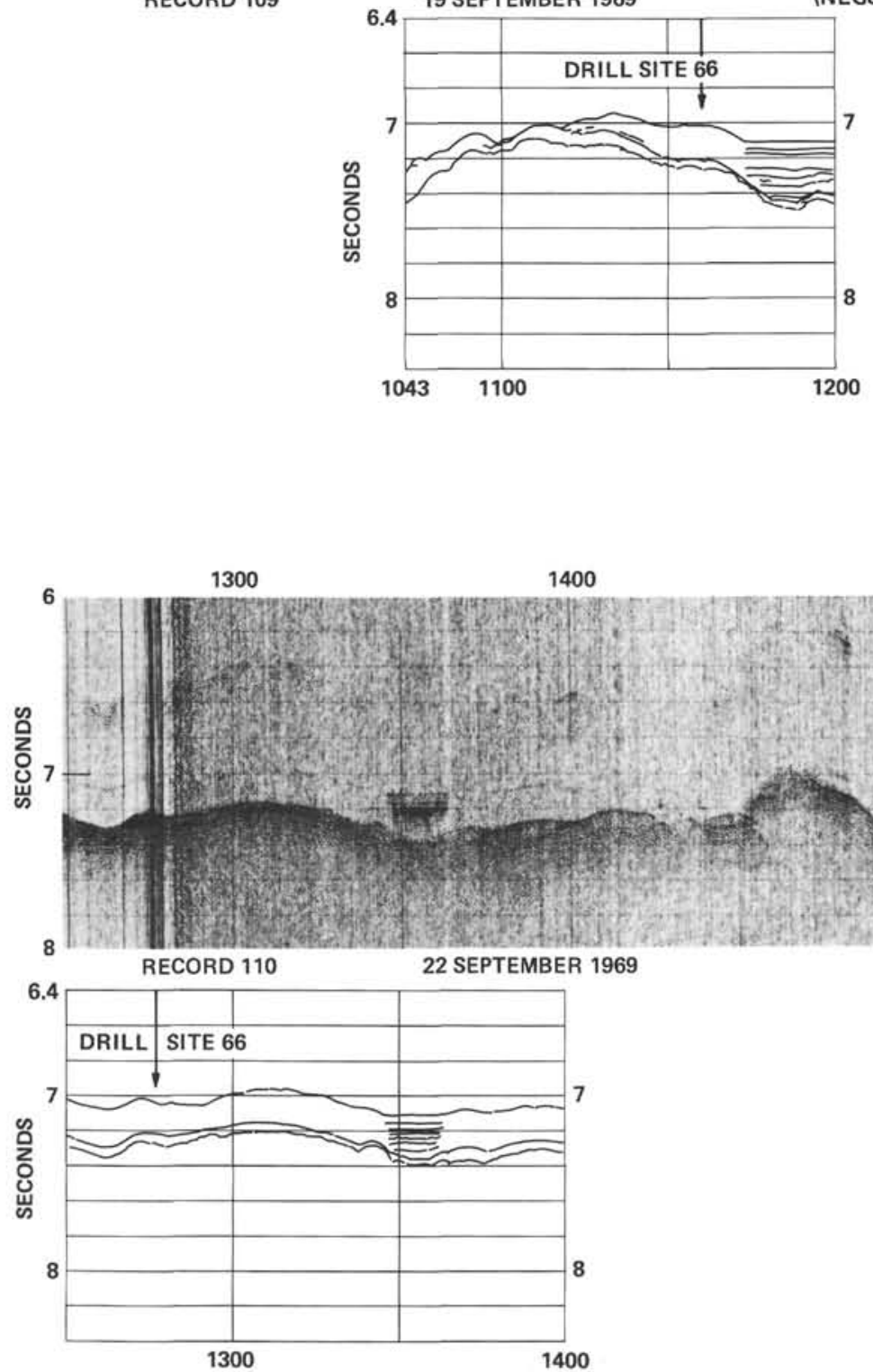

1500

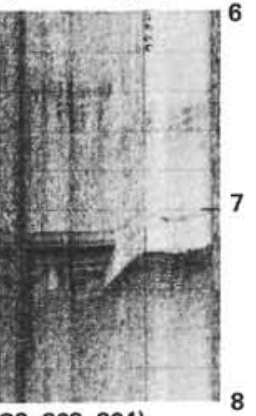

NEGS. 203, 204)

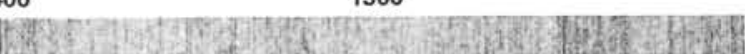

III 6

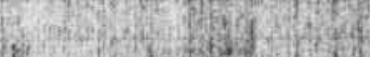

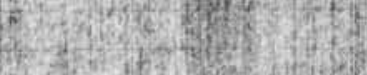

7y.

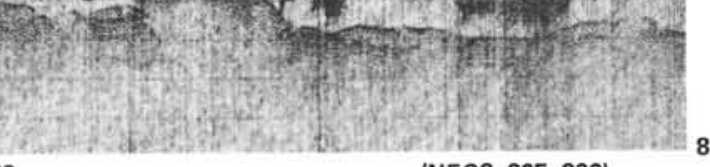

(NEGS. 205, 206) 

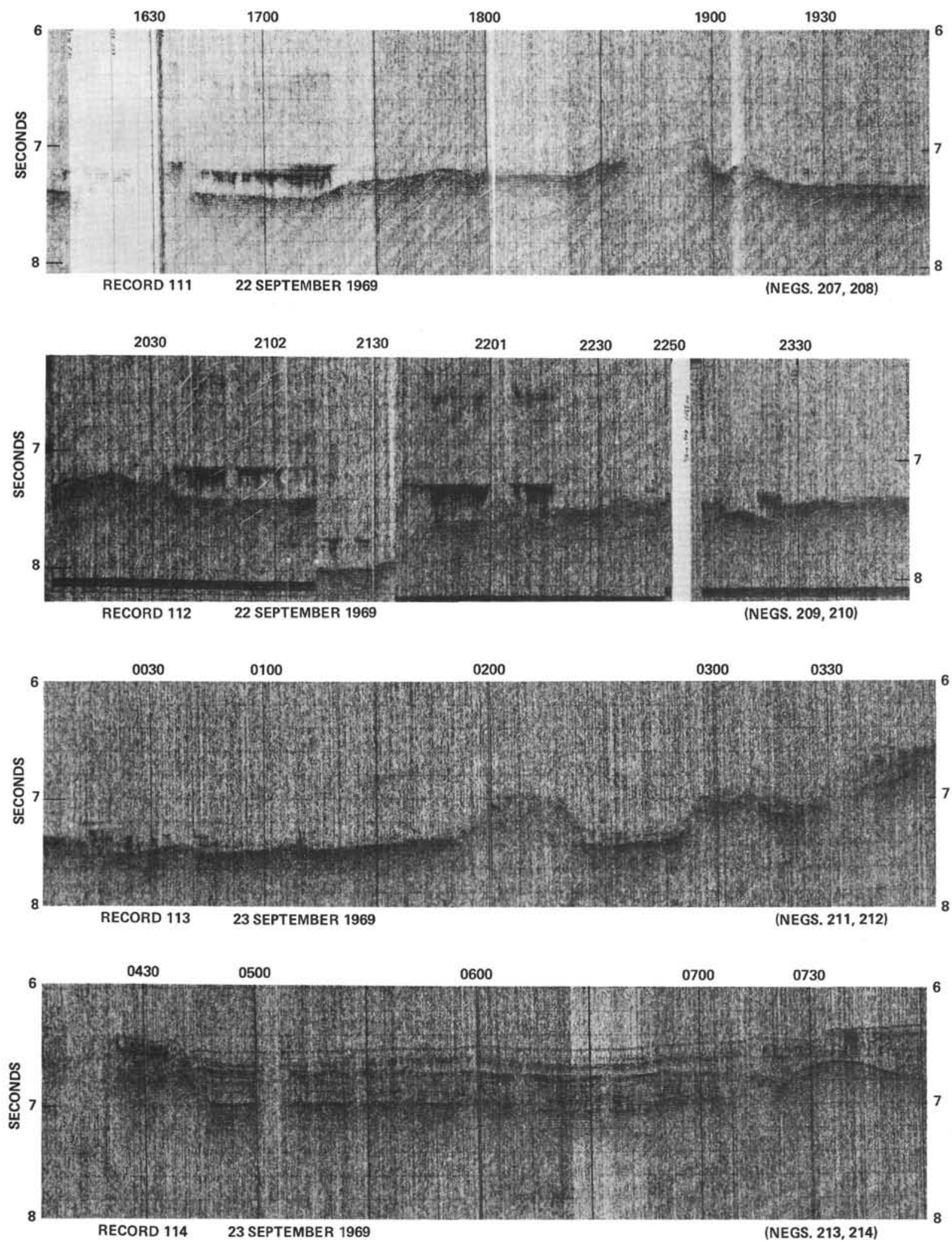


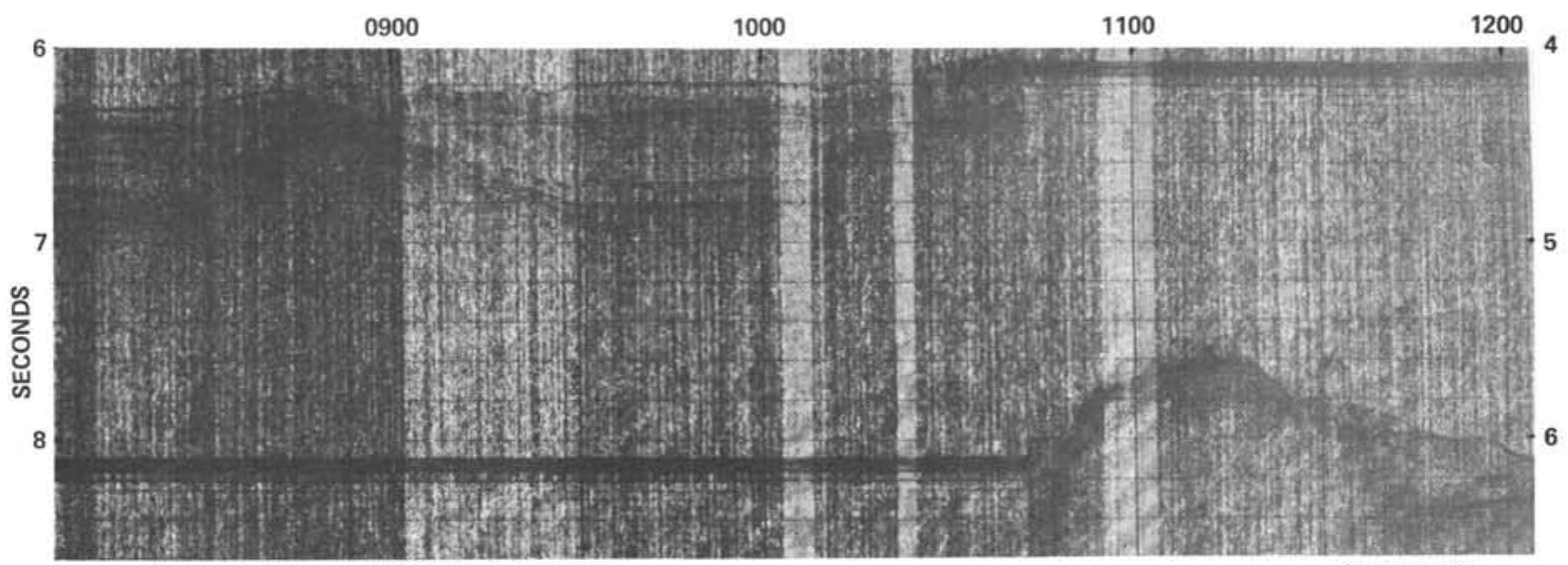

RECORD $115 \quad 23$ SEPTEMBER 1969

(NEG. 215)

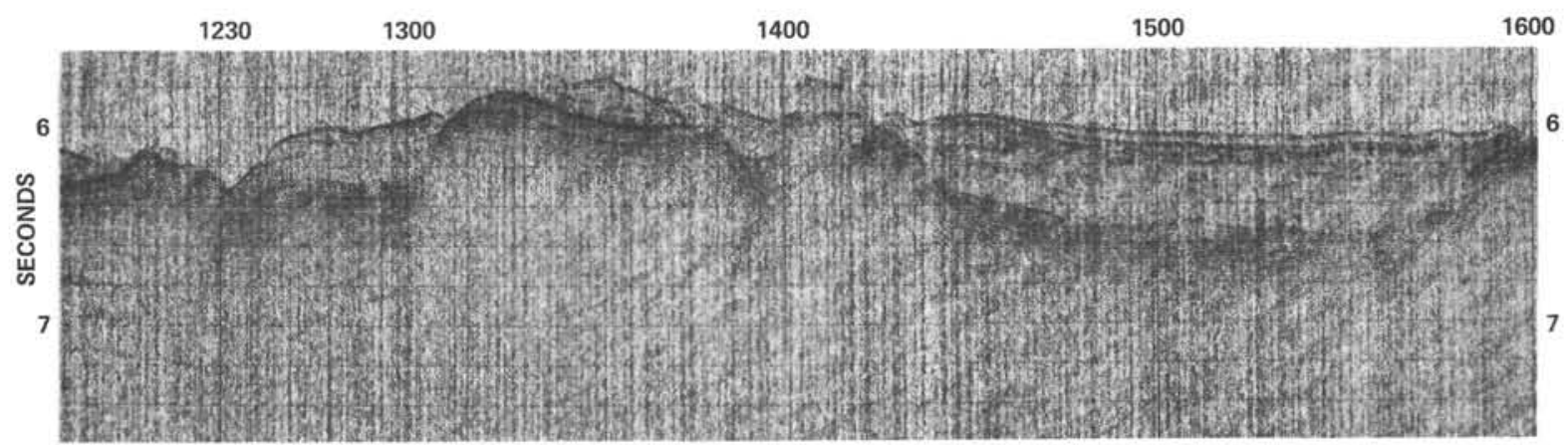

RECORD 116

23 SEPTEMBER 1969

(NEGS. 216, 217)

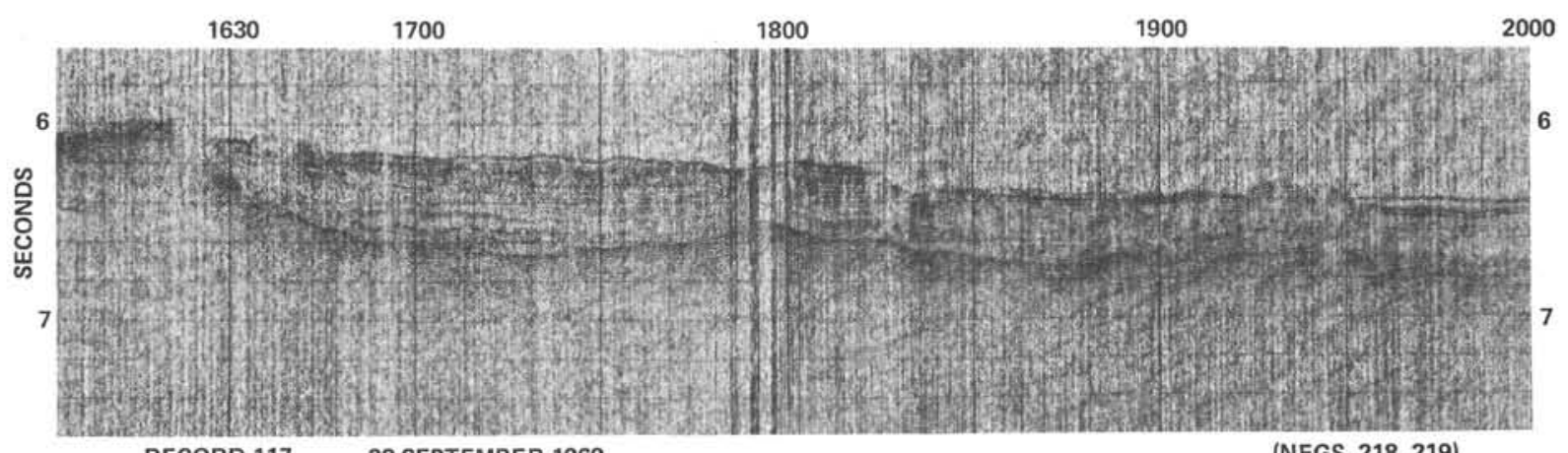

RECORD 117

23 SEPTEMBER 1969

(NEGS. 218, 219)

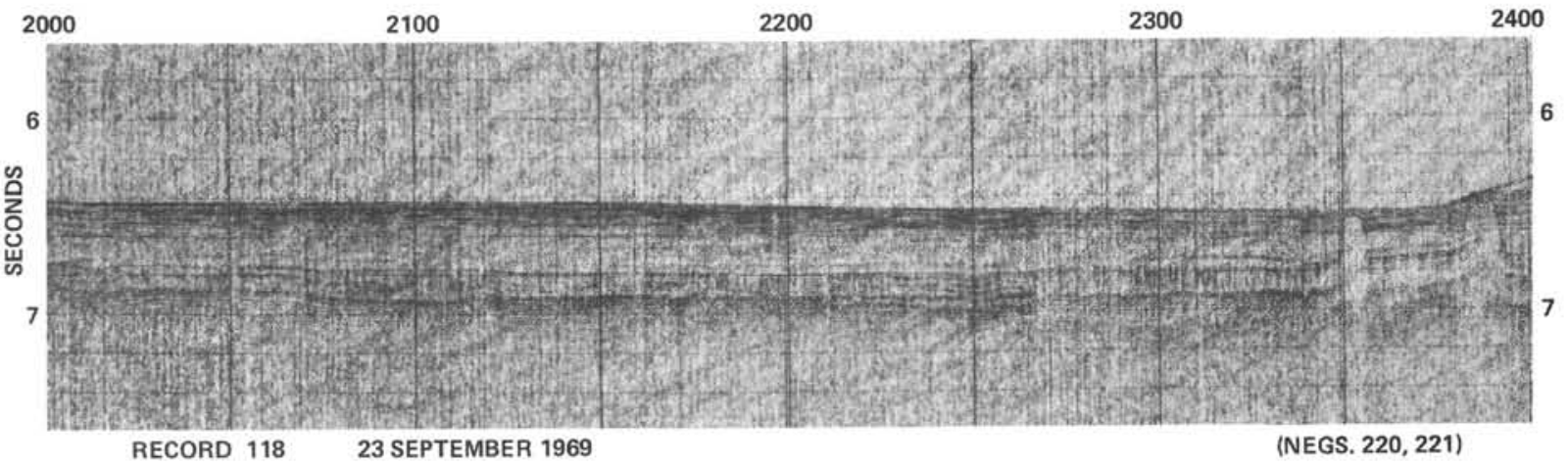



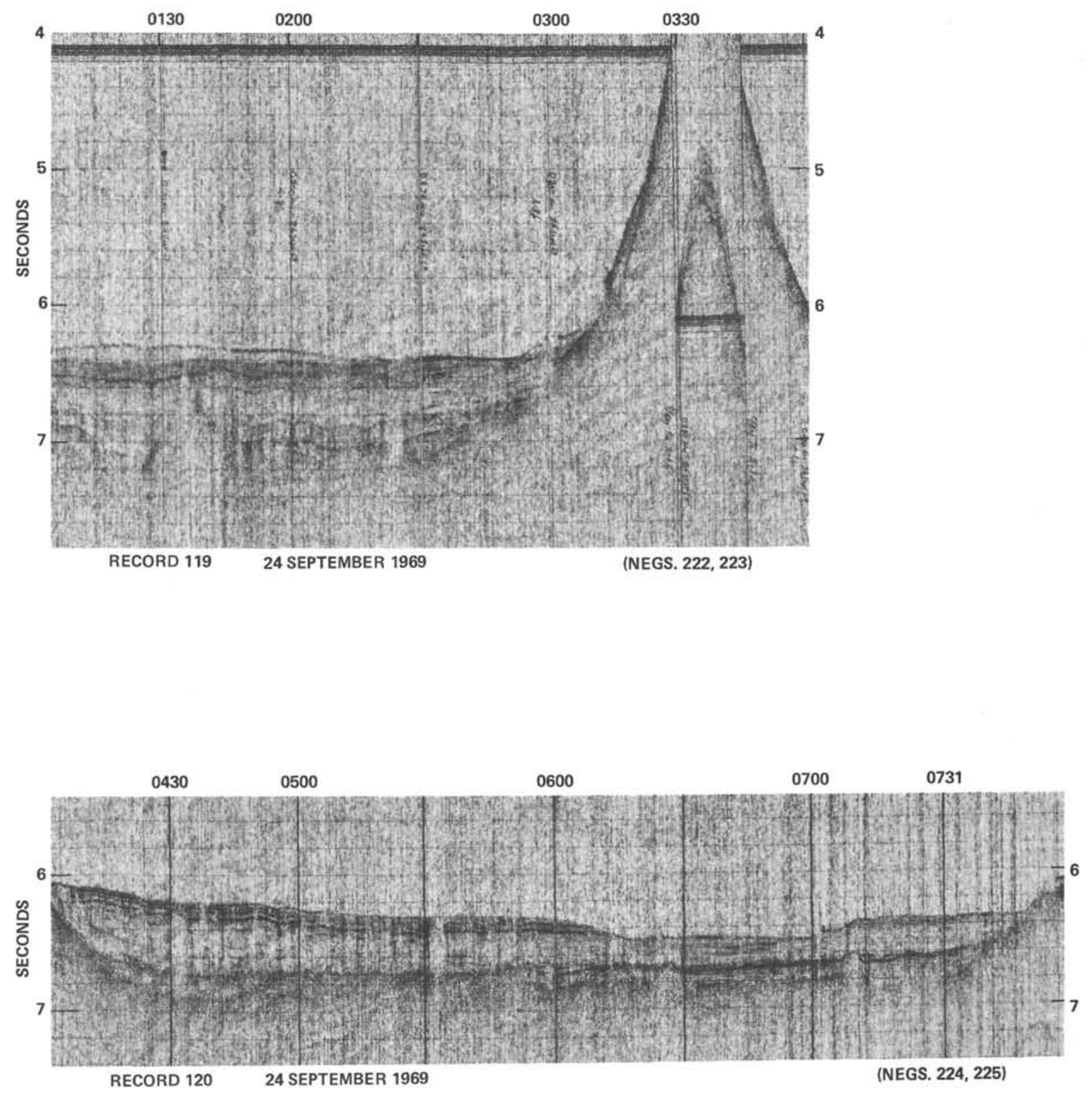

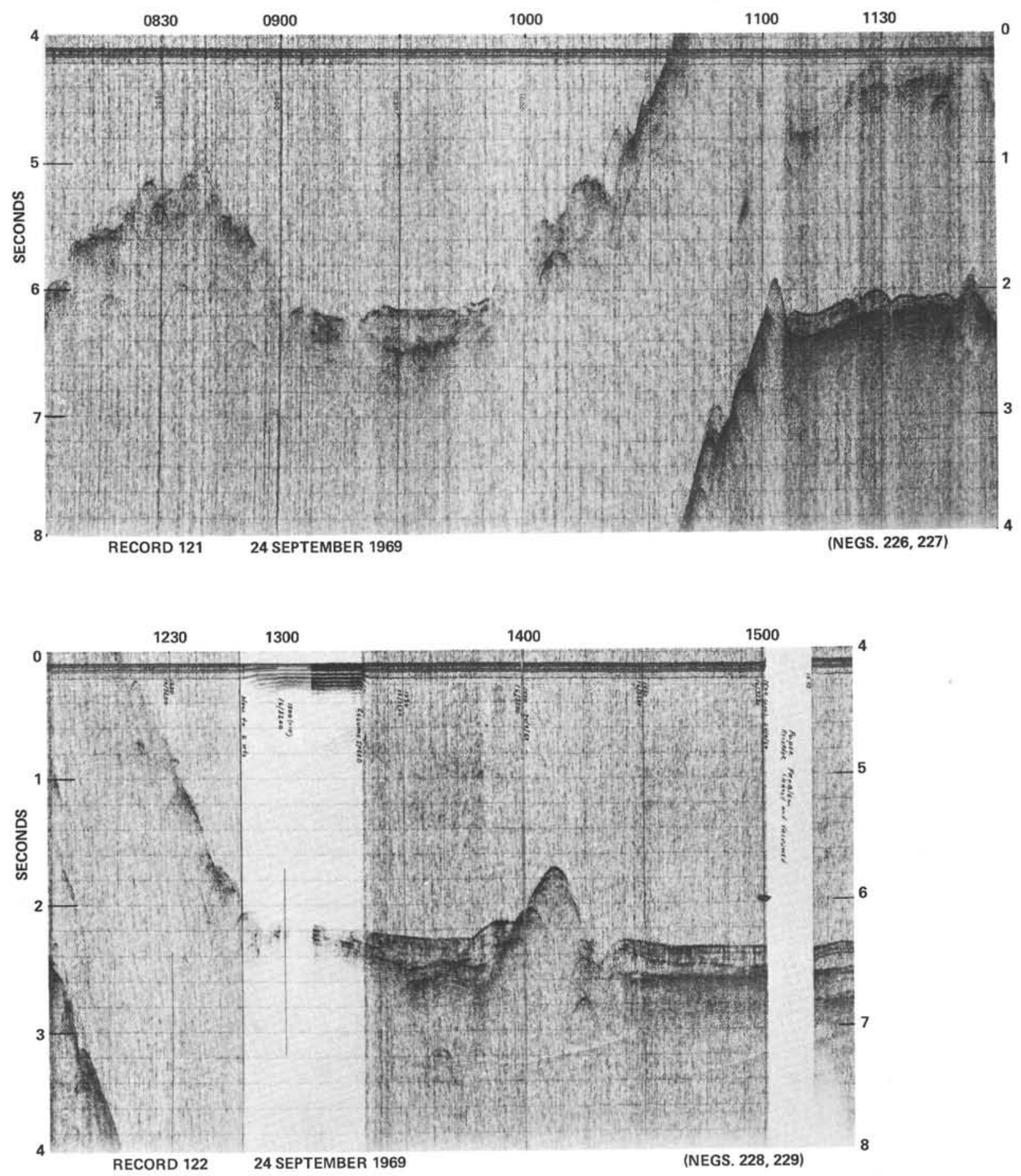

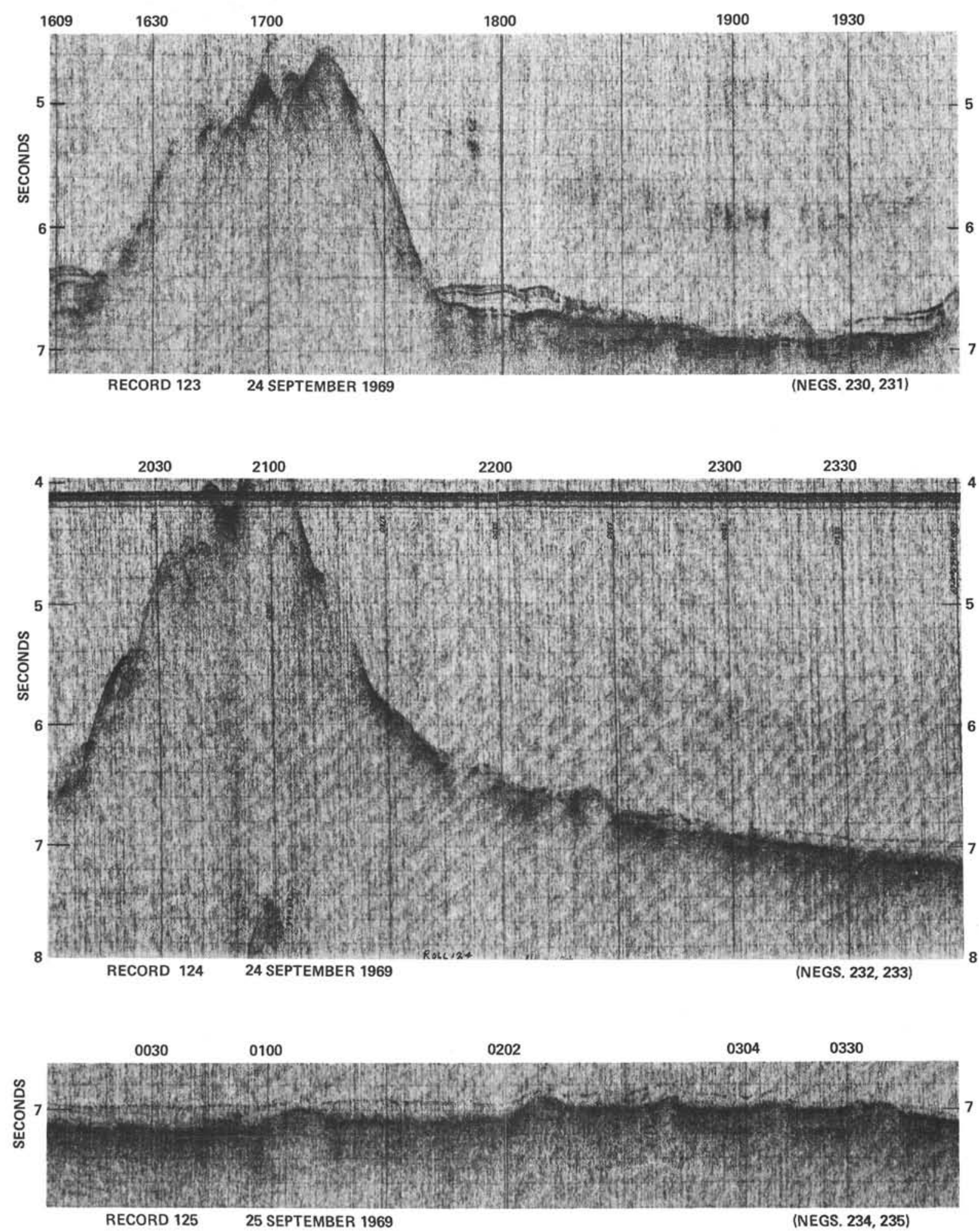

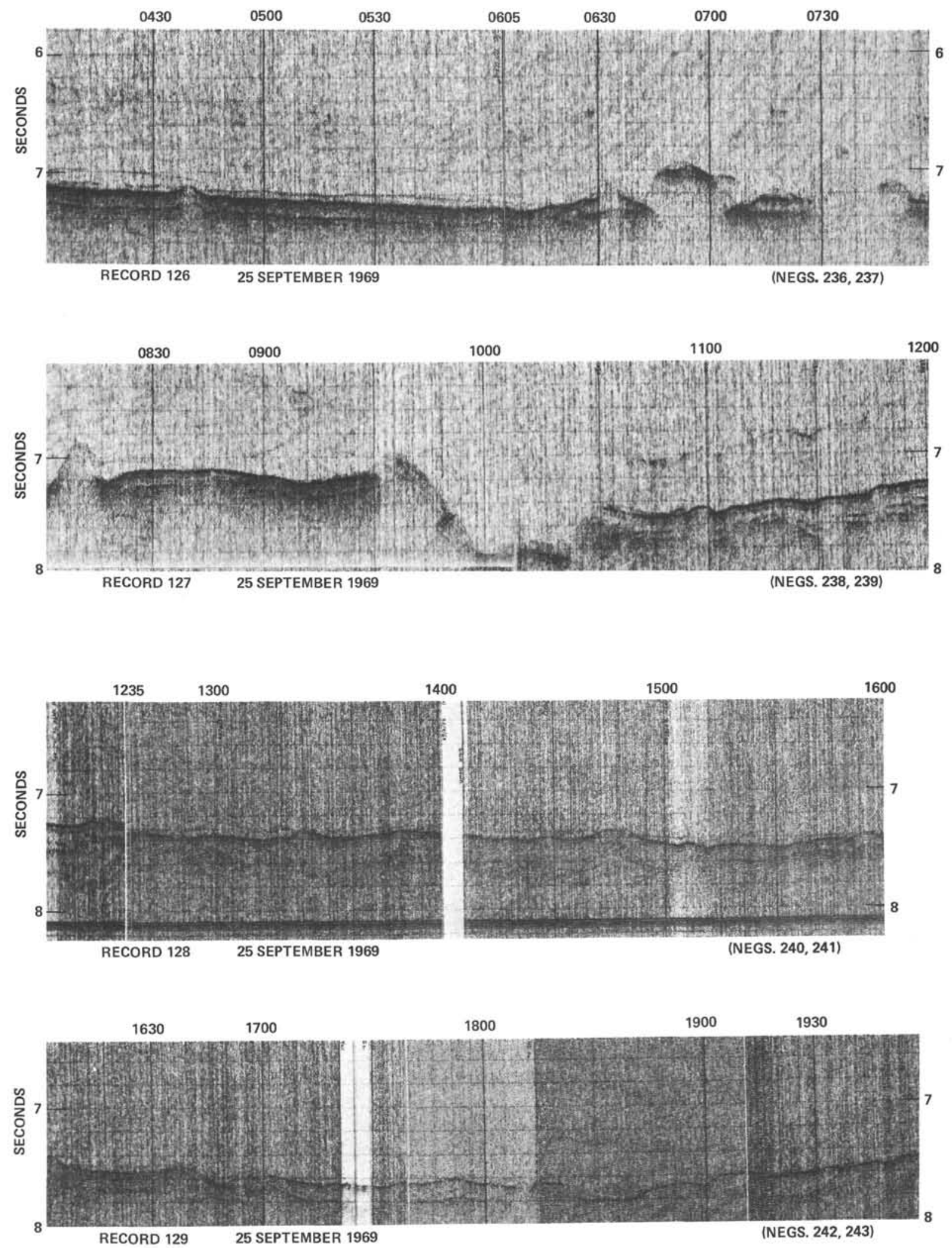

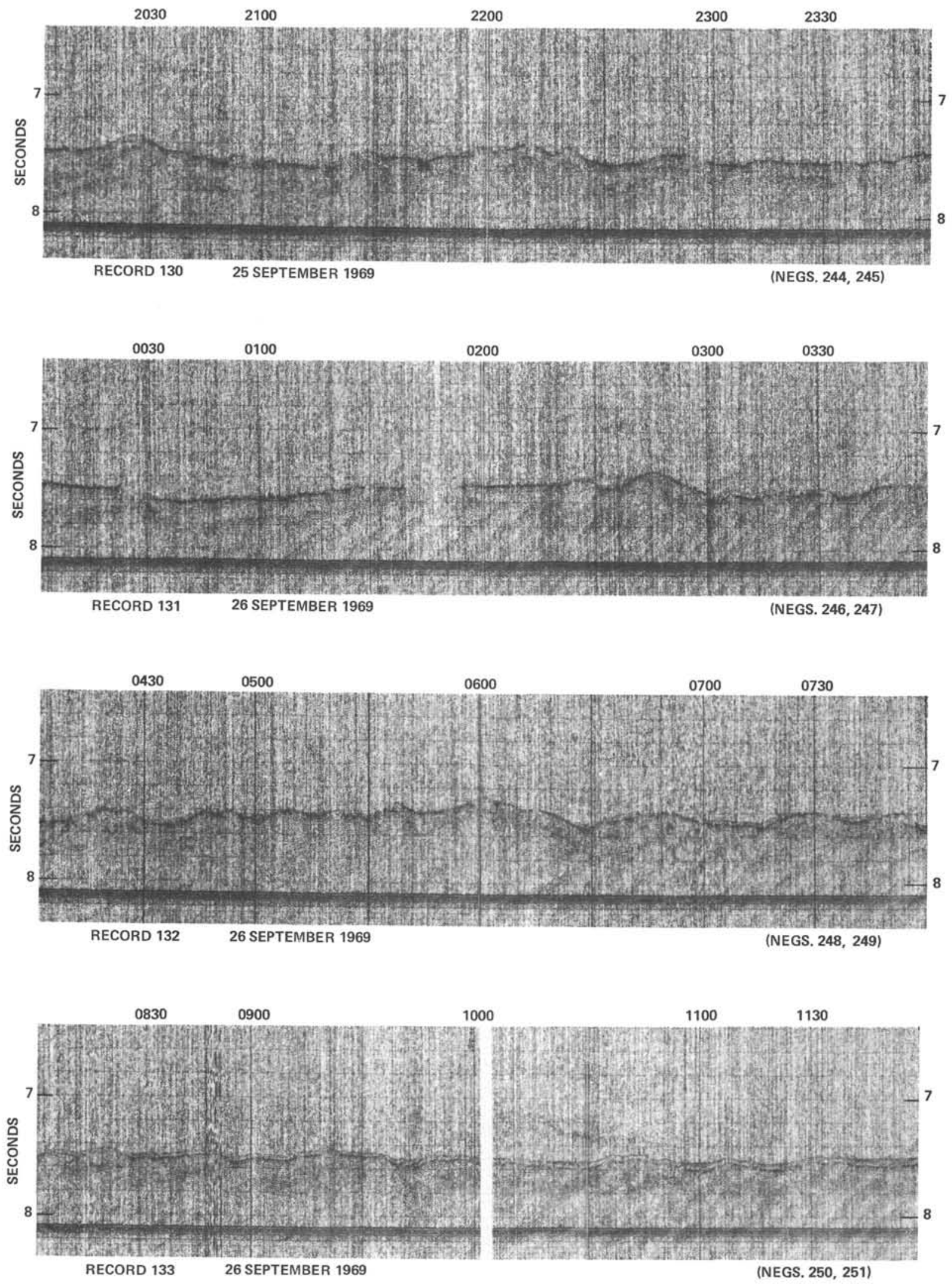

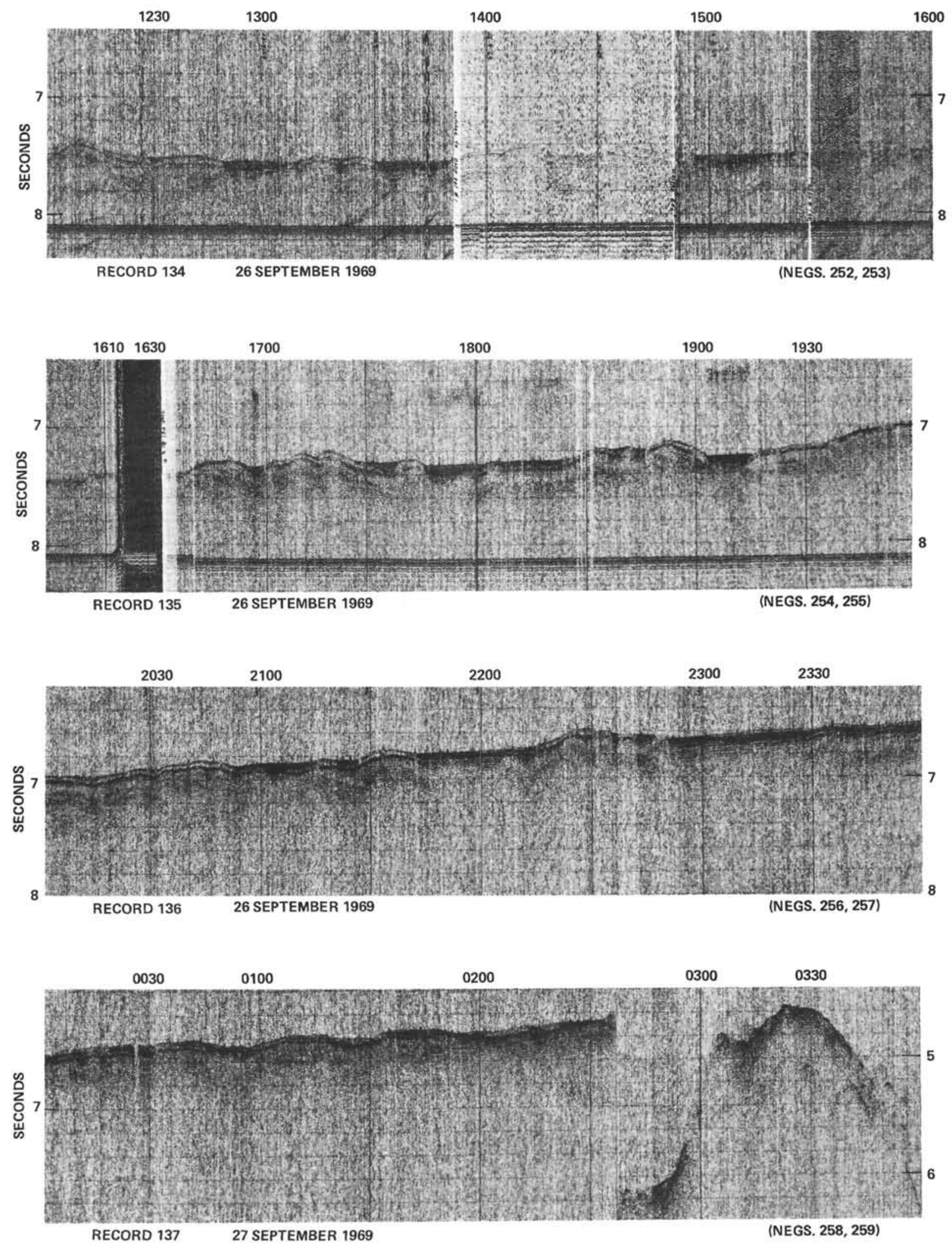


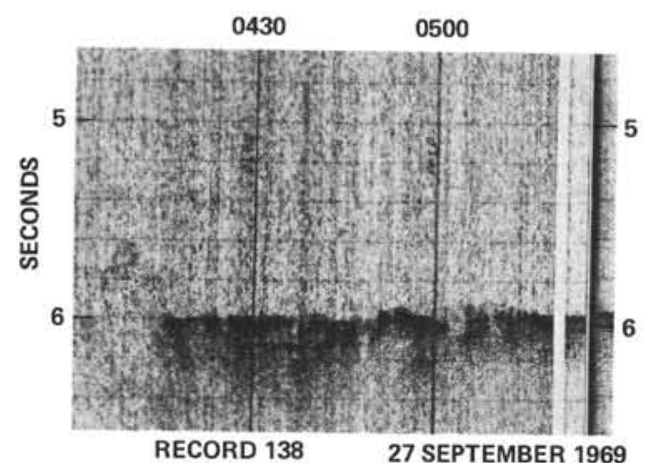

(NEG. 260)
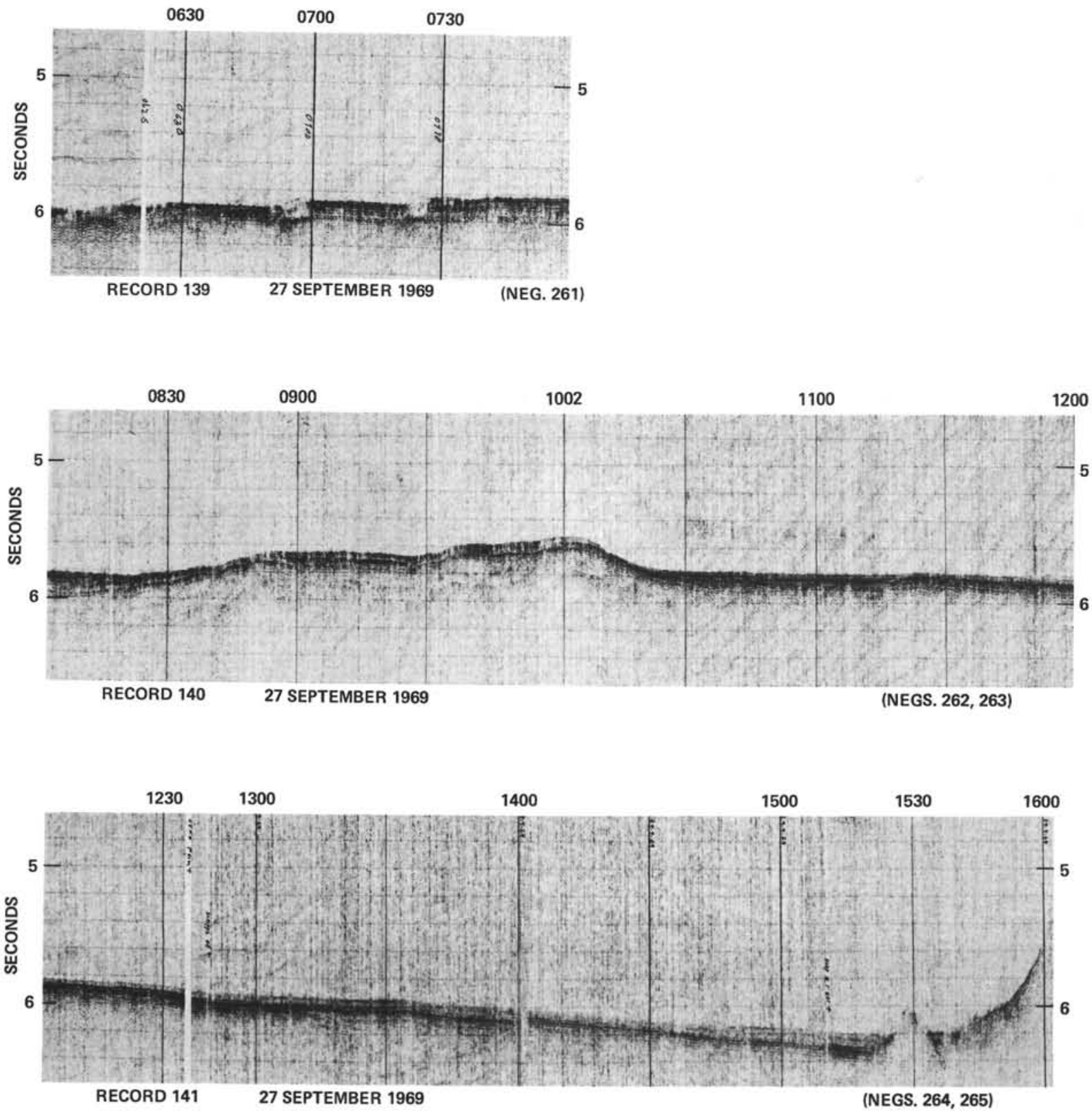

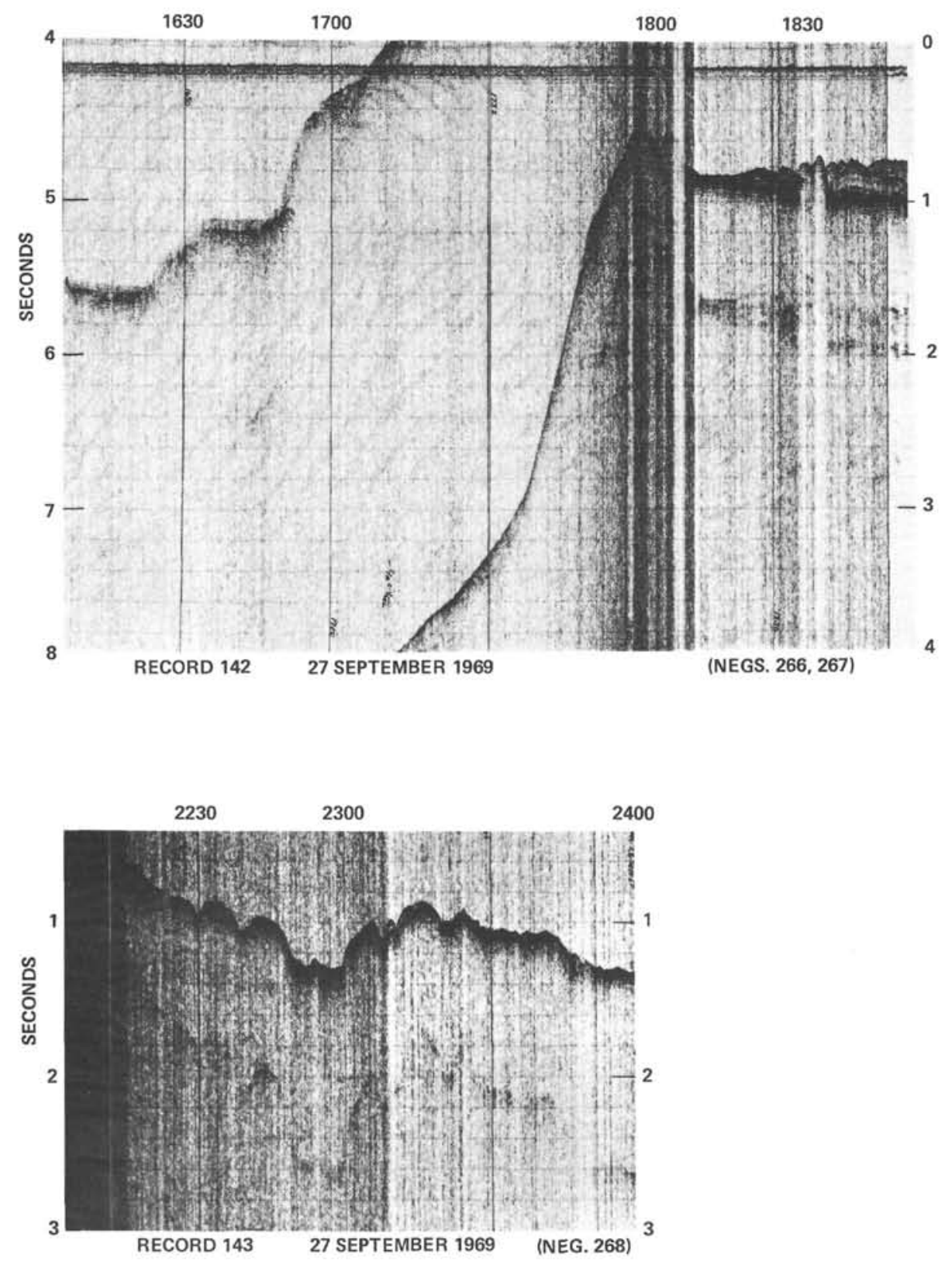

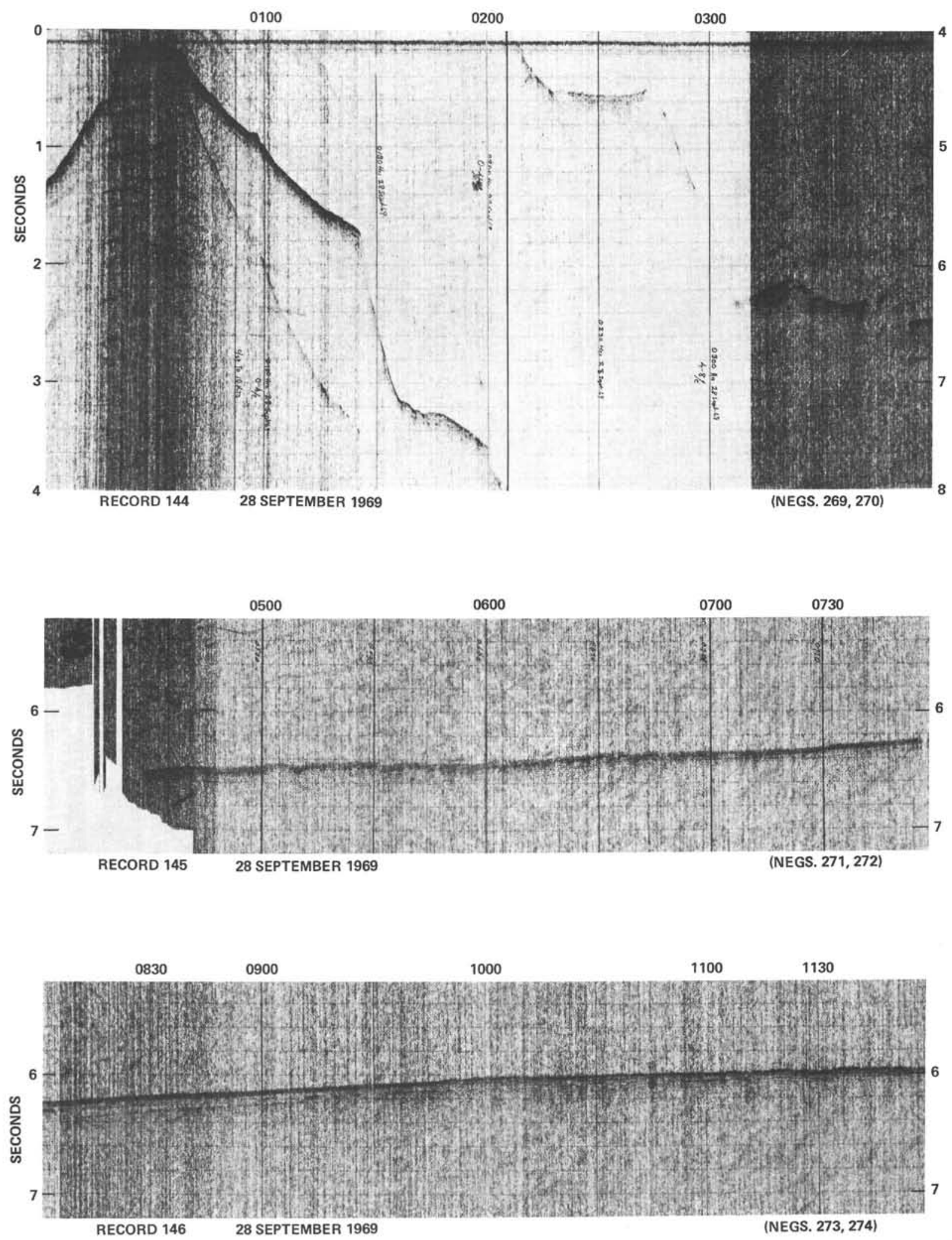

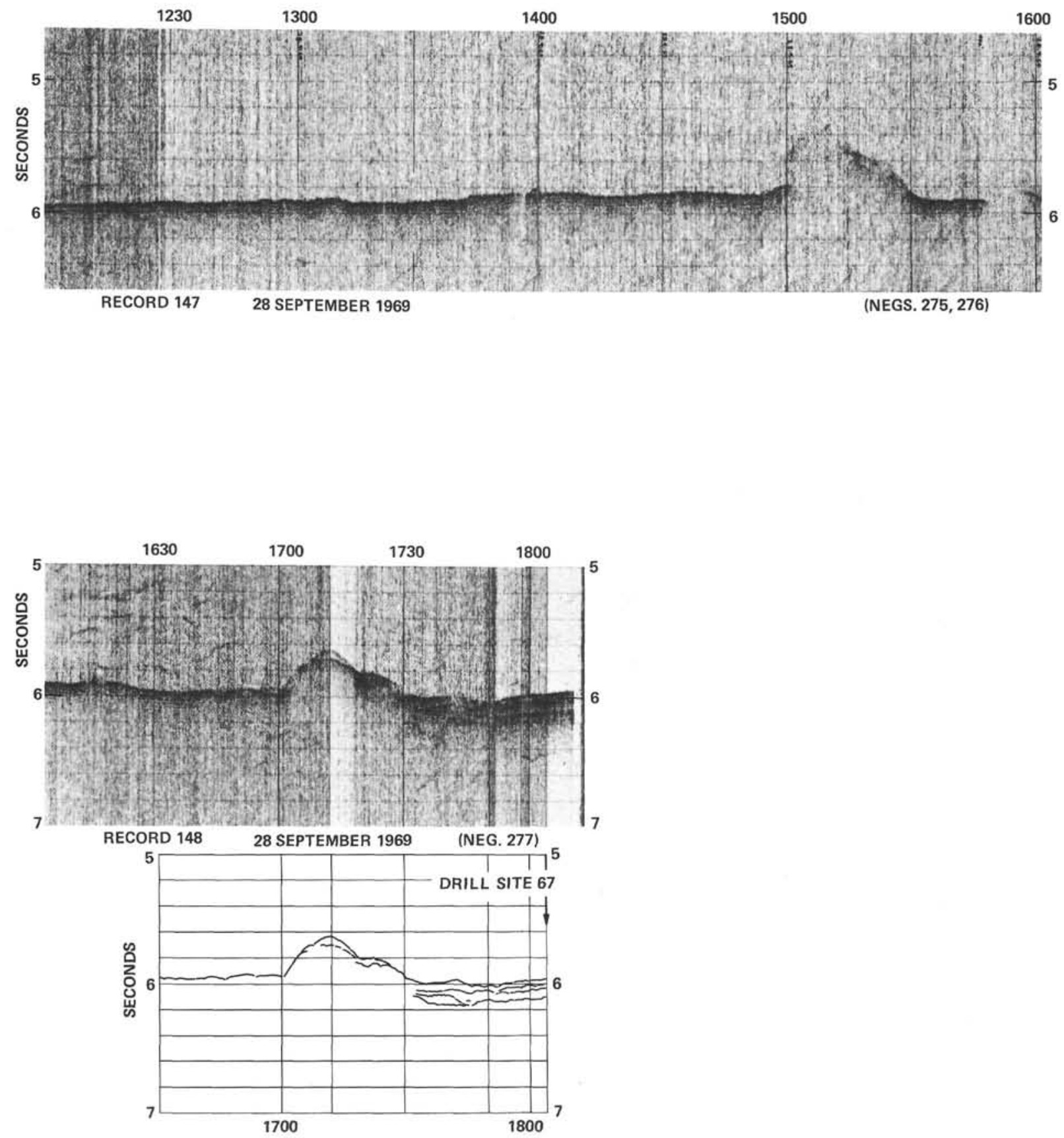